STATE OF ILLINOIS

DEPARTMENT OF REGISTRATION AND EDUCATION

DIVISION OF THE

NATURAL HISTORY SURVEY

STEPHEN A. FORBES, Chief

Vol. XIII. BULLETIN Article V.

\title{
CONTRIBUTIONS TO A KNOWLEDGE OF THE NATURAL ENEMIES OF PHYLLOPHAGA
}

BY

JOHN J. DAVIS

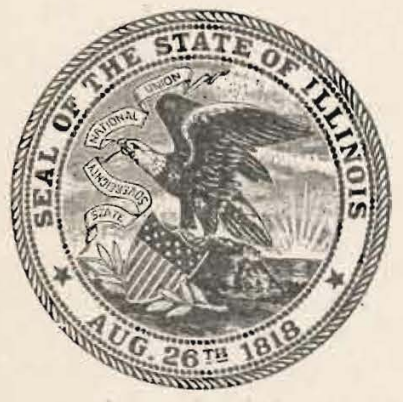

PRINTED BY AUTHORITY OF THE STATE OF ILLINOIS

URBANA, ILLINOIS

February, 1919 


\section{ERRATA}

Page 97, line 17, for first larval read pupal.

Page 112, in legend, for jonessi read jonesii.

Page 114, in legend', for or read of.

Page 125, line 4, for Bonosa read Bonasa.

Page 131, in legend, for hirundinaceus read hirudinaceus.

Page 138, last line, for coccoon read cocoon.

Plate XII, explanation page, next to last line, for acrivora read aerivora.

Plate XIII, explanation page, next to last line, for White-grubs read White-grub.

Page 293, Figure $5 a$ was reversed in printing, and the two items of the legend should change places.

Page 515, second table, for Pelocoris femorata read Pelocoris femoratus. 
ARTICLE V.-Contributions to a Knowledgc of the Natural Enemies of Phvllophaga* BY JoHx J. DAvis, Entomological Assistant, Cereal and Forage Crop Insect Investigation, Bureau of Entonology, U. S. Department of Agriculture.

\section{INTRODUCTION}

On account of the difficulty of controlling the common white-grubs, which pass ninety-five per cent. of their life under ground, their natural enemies are of unusual importance to the farmer. No one species of animal can be regarded as the most important check on the increase of the grub, but of its insect enemies the black digger-wasps belonging to the genus Tiphia are undoubtedly the most generally common and widespread, and are among the most effective insect parasites of white-grubs. In some sections the yellow-banded digger-wasps of the genus Elis are abundant, and in others asilid larvae of one species or another are of considerable inportance. Two-winged flies of the ortalid genus Pyrgota and others of the family Tachinidae parasitize the beetles, are generally distributed, and serve as significant cliecks. Among the native mammals and birds the skunk and crow stand out as models of efficiency in grub eradication. Diseases of various kinds are effective sporadically, but their occurrence is too infrequent, too local, and too dependent on weather conditions to make them as generally usefut and reliable as the insects, mammals, and birds mentioned above.

The efficiency of certain of the enemies of the white-grubs has been repeatedly demonstrated. During 1915 a nematode disease became evident in some sections, and heavily infested fields were practically freed of white-grubs by the action of this parasite. In another section. during the same year, a protozoan disease eradicated the pest in some fields. The black digger-wasps have undoubtedly controlled the grub in some sections where the pest once wrought havoc to corn crops. Adversely, the destruction of wild game, including birds and nammals, is apparently responsible in part for the increasing abundance of such destructive pests as white-grubs. These insects are seldom so injurious or wide-spread as were the destructive broods of 1912 and 1915 , and their superabundance at any given time or place is apparently due to a decrease in the natural enemies which under ordinary conditions would keep them under reasonable control.

The value attached to their natural enemies in the control of the white-grubs is well shown by the fact that the Porto Rican sugar-growers

* The specific symonymy of this genus here adonted is that given by Glasgow in his revision of the synonymy of the genus Phyllophaga Harris (Lachnosterna Hope)-Bul. I11. State Lab. Nat. Hist., Vol. 11, Art. 5, Feb., 1916. 
have had an expert traveling throughout the United States for several years gathering parasites for use in the control of the white-grubs in Porto Rico, where they are very injurious to sugar-cane and other crops.

The object of this paper is to place on record our preliminary observations, to bring together the complete records of white-grub enemies for the use of others in this work, and to stimulate the study of the beneficial species occurring in different localities. The writer is especially anxious to receive living parasites from all sections of the country, and persons able and willing to cooperate are requested to notify us of that fact.

The writer is especially grateful to Messrs. W. R. Walton and H. E. Smith and Dr. J. M. Aldrich, who determined most of the dipterous parasites, and to Mr. A. B. Gahan for the determination of the Hymenoptera. Thanks are due the various state and bureau officials mentioned hereafter in the text, who have furnished specimens used in our work. We also take this opportunity of expressing our appreciation of the cooperation and assistance of colleagues who have served at the Lafayette Laboratory from time to time, including Philip Luginbill, C. W. Creel, W. J. Phillips, R. J. Kewley, A. F. Satterthwait, H. J. Hart, F. A. Fenton, S. L. Mason, H. Fox, D. G. Tower, and D. A. Ricker. Photographs for figures $8,10,12,28,30,31,41$, and 42 of the plates were taken by Mr. J. H. Paine; and the excellent drawings for the text illustrations were, with a few exceptions, made by Miss E. H. Hart and Mr. W. R. Walton, of the U. S. Bureau of Entomology, for which the writer expresses grateful acknowledgment. The writer is further indebted to his brother, H. A. Davis, for the lettering of charts I and II.

To Dr. S. A. Forbes, the writer wishes to express his gratitude for the inspiration and encouragement received when as a member of the staff of the State Entomologist's office he first attenpted studies on white-grub enemies, and for the opportunity afforded for the publication of this paper.

\section{Ecological Considerations}

Although this paper is intended primarily to present the known facts relative to the individual enemies of Phyllophaga, it seems desirable briefly to note some of the relations existing between the many parasites, hyperparasites, and predators, and their hosts. The two accompanying charts present these facts graphically and require but few words of explanation.

Chart I shows in a concise form the enemies of Phyllophaga from egg to adult.

Chart II is a diagramatic illustration of the relations existing between Phyllophaga and its enemies, but does not take into consideration the interrelations of Phyllophaga and other beetles such as Cotalpa, Cyclocephala, and Ligyrus, which are attacked by some of the same enemies, since this would complicate and confuse the diagram. 


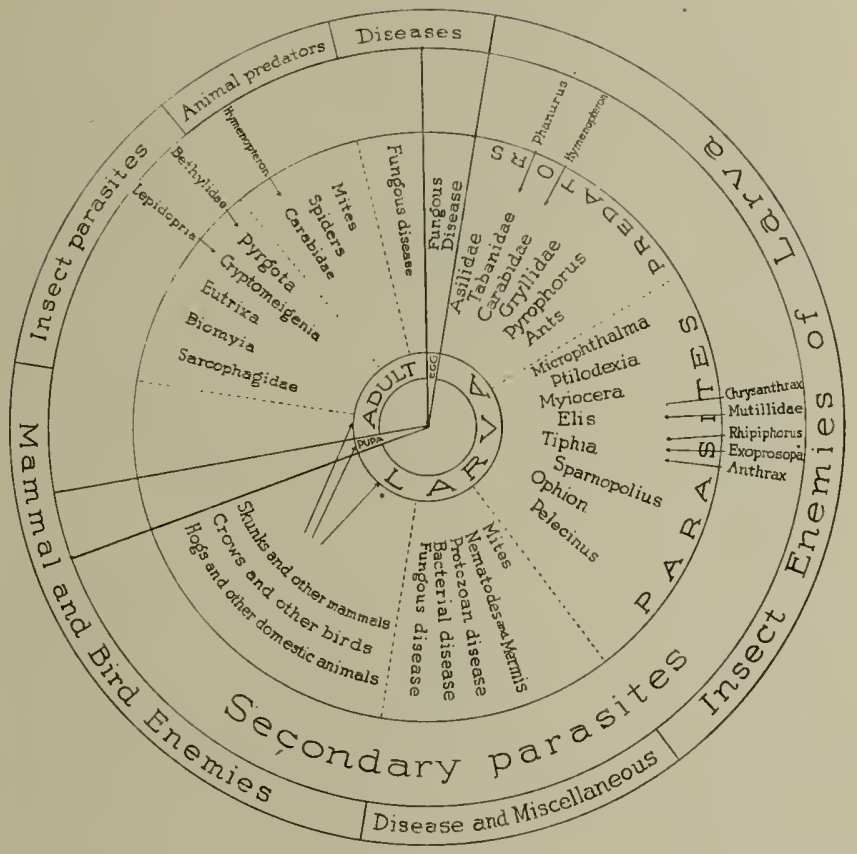

Chart I. Concise exhibit of the enemies of egg, larva, pupa, and adult of Phyllophaga. 
56

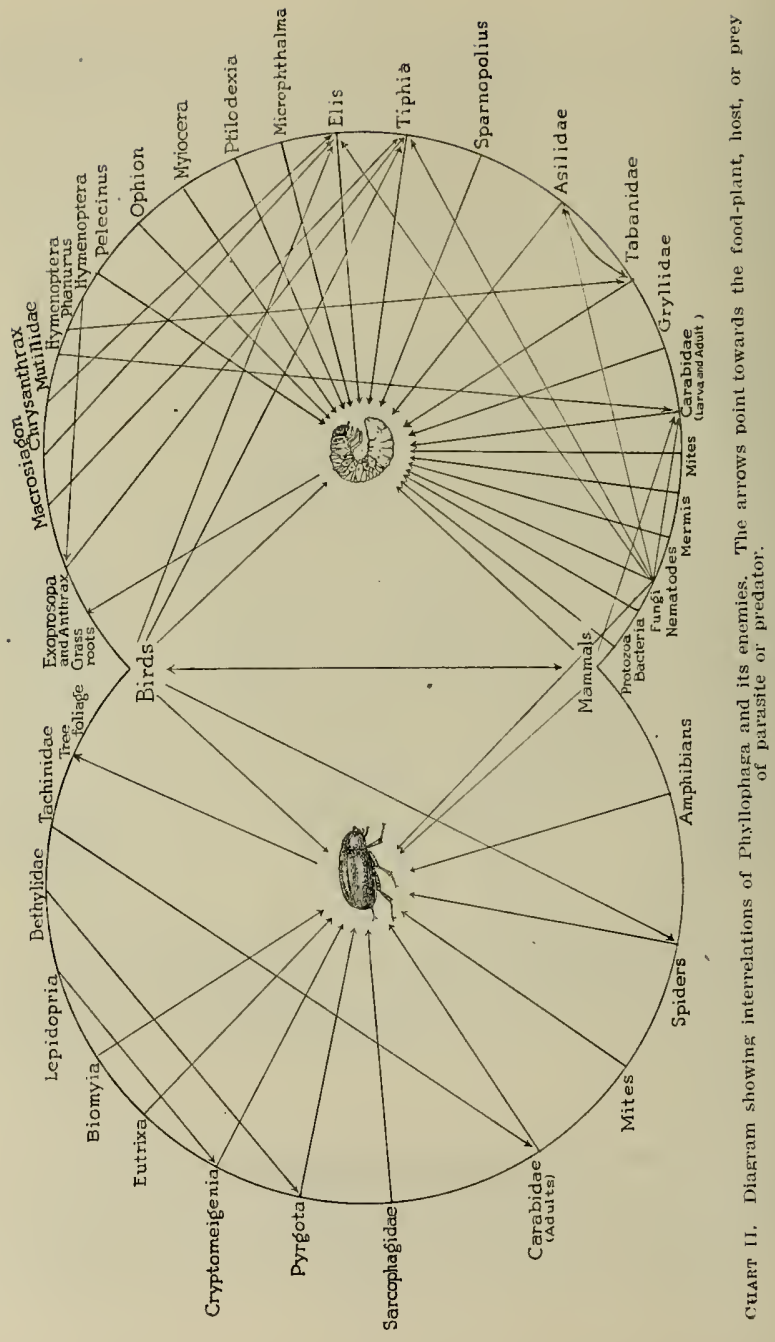


It will be noticed that the length of the various stages of the host has a direct relation to the number of enemies in each stage. The egg and pupa each exist as such only about one month and, in addition, are well protected in their earthen cells, hence we find but few natural enemies affecting them. On the other hand, the larva, which exists for a nuch longer period, is beset with enemies, among the most important of which are digger-wasps belonging to the genera Tiphia and Elis, which are thoroughly adapted to burrowing through the soil in search of their host. These parasites have undoubtedly bcen responsible for the practical eradication of grubs in ceratin areas-sometimes rather restricted, which can be accounted for by the fact that Tiphia at least, on account of its large body and comparatively snall wings, is unable to fly any great distance. Likewise, Tiphia, as well as all other whité-grub parasites, is somewhat checked in its increase by the length of its life cycle as compared with that of Phyllophaga, the parasite having a one-year, and the host, as a general rule, a three-year, cycle, and although grubs of a particular size are present each year there is seldom more than one destructive brood; that is, an abundance of a grub of a particular size occurs only every three years, and althongh the digger-wasp parasites may become very abundant one year they are likely to decrease in numbers the following year on account of lack of host material. Another important detrimental influence affecting these wasps is plowing, which exposes the cocoon to heat and drouth in summer, to the cold of winter. and to the attacks of predaceous mammals and birds.

The adult dipterous flies of the genera Microphthalma and Ptilodexia are not adapted to enter the soil in search of their prey as is Tiphia, and must therefore deposit their young in cracks and crevices of the earth, the larvae being obliged to search for the grubs of their host insect; hence it appears that these species are more abundant in sandy and porous soils which offer the least resistance to a search for the grubs. Whether the flies are able to locate infested areas and thus deposit their progeny in favorable locations is not known, but it seems likely that this is the case. The hymenopterous enemies of the genera Pelecinus and Ophion, and the Diptera belonging to the bombyliid genus Sparnopolius are so rarely encountered that they are of no appreciable importance in their influence on the grub. population. The beetles of the family Carabidae and their larvae are naturally predaceous and live in or on the surface of the soil, being always alert in their search for softbodied prey. Soil-inhabiting asilid and tabanid larvae are likewise generally predaceous, but the Asilidae are much the more important as white-grub enemies because they inhabit upland soils which are favorable to the development of most Phyllophaga species, while the Tabanidae are typically low-ground and marsh-inhabiting insects. Likewise we have in the Asilidae a most interesting example of a life cycle conforming to that of Phyllophaga; at least it appears that two species of Promachus have a three-year cycle as does the host, and, furthermore, they are able to live for long periods without food-an adaptation of 
the greatest importance when we reflect that the larvae must forage, and apparently blindly, through the soil in search of grubs which may be few and far between. The Asilidae are also more or less beneficial in the adult stage as predaceous on other insects, though not attacking May-beetles since the former are diurnal and the latter nocturnal in habit of flight. On the other hand, the adult Tabanidae, or horse-flies, are well-known stock pests. The various nematodes and the protozoan, bacterial, and fungous diseases of Phyllophaga are but little understood. None of these agencies are known to be consistent checks on the multiplication of white-grubs, but occasionally one or the other of them appears in such force as to wipe out the entire white-grub population in some areas. Favorable climatic conditions and abundance of the grubs are the two most important factors promoting the appearance of the diseases; and, unfortunately, these conditions can not be duplicated in the field by artificial means, and they occur too rarely to act as reliable checks. The fungous diseases also affect the insect parasites of whitegrubs.

The various native mammals and birds are among our most dependable friends, especially such animals as the skunk and such birds as the crows and robins, which seem instinctively to scent the grubs and May-beetles and search the soil for them. Many of the other animal predators, especially birds, are dependent on the plow to turn up the grubs.

Undoubtedly the increase in white-grubs in certain sections of the country is due largely, if not wholly, to the destruction of the wild mammals and birds which in years past prevented such insects from increasing to abnormal abundance.

Respecting the insect parasites of the adult May-beetles, it should be noted that all excepting the sarcophagids, most of which are probably not true parasites, are nocturnal in habit as is their host. Most May-. beetle species are entirely nocturnal, feeding on the foliage of trees at night and hiding beneath rubbish or in the soil by day. The tachinid parasites of the adult deposit their eggs on the beetles while the latter are quietly feeding or copulating and are least likely to be disturbed; but the ortalid flies of the genus Pyrgota attack the beetles in flight. The Pyrgota species deposit their eggs in the bodies of the May-beetles, the opening of whose elytra in flight exposes the only part of the body soft enough to be pierced by the ovipositor of the parasite. A few sarcophagids may be regarded with reasonable certainty as May-beetle parasites, and it is interesting to note that they have been reared only from $P$. lanceolata and $P$. cribrosa, which are day-flying species, as are these parasites.

When we further reflect that these enemies are likewise attacked by parasites, that some birds and mammals which destroy Phyllophaga may also destroy the beneficial parasites, that the adult of one predaceous larva may prey on the adult of a similar predaceous larva, and that the 
predaceous larvae likewise may attack one another, we begin to realize the immense complexity of the interrelations of these animals.

These few remarks indicate the importance of studying more thoroughly the interrelations of insect pests and their enemies, and especially the effects of varying conditions on each-problems which are practically untouched, and yet ofter possibilities of the greatest economic importance.

\section{Parasites of the larva}

\section{The Black Digger-wasps (Thiphit spp.")}

The black digger-wasps are without doubt the most efficient and abundant of the many parasites known to attack Phyllophaga. One or another of the species of Tiphia parasitic on our common white-grubs (Phyllophaga spp.) is to be found in greater or less abundance in every section of the United State east of the Rocliy Mountains.

The adult wasps feed on the nectar of various roadside flowers, but much of their life is spent in the soil and therefore they are not frequently encountered. However, the rather common occurrence of their tan-colored, woolly, egg-shaped cocoons in the soil, to be seen in following the plow in almost any section of the country, is sufficient proof of the beneficial activity of these wasps.

The black digger-wasps were first recoginized as parasitic, or more strictly speaking ectoparasitic, on white-grubs of the genus Phyllophaga by Riley, who in $18 \% 4$ published an account of the habits and life history of a species which he referred to Say's Tiphia inornata (j9) $\dagger^{\dagger}$ Few additional facts were learned until 190\%, when Forbes published an account (26) materially increasing our knowledge. Up to the present time, however, several species attacking white-grubs have been confused and practically nothing has been known of the different kinds. From our breeding records four species are now known to attack Phyllophaga larvae in the United States, each depositing its eggs on a different part of the grub, and several other species are parasitic on related grubs, such as Anomala, Ligyrus, Cyclocephala, Dyscinetus, etc. A fifth species ( $T$. parallela Smith) is a parasite of the grub Phytalis smithii-a grub very much like our Phyllophaga-in the British West Indies, and, according to Nowell (53), the egg of this wasp is laid in a position identical with that of the egg of $T$. punctata on the Phyllophaga grub.

T. punctata Rob., our commonest species, lays its egg on the dorsum of the thorax of the grub-or on the first or second abdominal segmentustrally on the second or third thoracic segnment, just to one side of the median line, in a groove of the folds of the skin; $T$. inomata Say commonly lays its egg on the under side of the thorax, usually between the legs, but occasionally beneath the first abdominal segment; $T$. transversa Say lays its egg on the under side of the abdomen, usually on the fourth

- Determined by Mr. A. B. Gahan, and afterward checked up by Gahan using a key prepared by Mr. J. R. Malloch

+ Numbers in parentheses refer to literature citations. 
or fifth segnent; and T. vulgaris Rob. is supposed to oviposit on the dorsum of the abdomen. In all cases the eggs are laid transversely and securely glued to the integument of the grub. It is interesting to recall in this connection some observations made by the writer in Illinois in 190 ; while working under the direction of Dr. S. A. Forbes. The position of Tiphia eggs and larvae on grubs was noted in many cases while grubs were being collected behind the plow, and in every case, in spring and early summer, the eggs or larvae were found on the under side of the thorax and between the legs of the white-grub and may have been those of Tiphia inornata. In fall, on the other hand-that is during September and October-of the 63 eggs and larvae of Tiphia observed, 28 (probably $T$. vulgaris) were on the dorsal surface of the abdomen near the anal end; 24 (probably $T$. punctata) on the dorsum of the thorax; and 1 (probably $T$. inornata) was on the under side of the thorax.

The time of appearance of the wasps differs with the species, $T$. punctata and $T$. transiersa appearing relatively late in the season, usually in the latter part of July or the first of August, while T. inornata appears early, that is from the latter part of April to the middle of May, and $T$. vulgaris issues from early May to July according to our records, which are meager for this species. Relatively speaking, inornata appears first, then vulgaris, and finally transversa and punctata, and since the wasps may live for a month or more, the species overlap considerably. The appearance of the different species at different seasons accounts for the supposition that Tiphia has several generations in a year; but our records show that under normal conditions there is only one annual brood in the latitude of Indiana.

Adult Tiphias are often found in June and later, on the flowers of such common roadside weeds as wild parsnip, aster, goldenrod, and milkweed, the males always predominating, but more often the female wasps are to be found in the fields, on the surface of the ground, or making short flights. The males are capable of making extended flights, but this the females are unable to do-except possibly for the first few days after emerging from the cocoons-owing to the larger size of the abdomen as compared with that of the wings. Usually the fenale wasps are found walking about over the surface of the ground in a quick. agitated manner, sometimes making short flights or jumps, with antennae continuously in motion, searching for evidences of their hosts. They make use of cracks, earthworm burrows, and possibly also of ant tunnels, in gaining an entrance into the soil, but not infrequently dig in directly, being admirably fitted to work their way through rather heavy soil with little apparent effort.

Outside of our cages, we have noticed copulation only in cultivated fields and along roadways, and always on the surface of the ground. Fertilization is not necessary to hatching, for we have often obtained fertile eggs from unfertilized females, but these eggs invariably yielded males. Phyllophaga grubs are the principal hosts of Tiphia, but we 
have reared $T$. punctuta from larvae attacking Ligyrus gibbosus and Anonala grubs, and have found Cyclocephala grubs bearing eggs of two species (probably $T$. punctata and $T$. inomata) in the field, these being however, exceptional cases. The female Tiphia stings if given opportunity, but the sting causes only a monentary itching, differing in this respect from that of the female Elis, which is sometimes quite painful. The species of Tiphia under discussion look very much alike, and a brief general account of their appearance is sufficient here. Indeed the

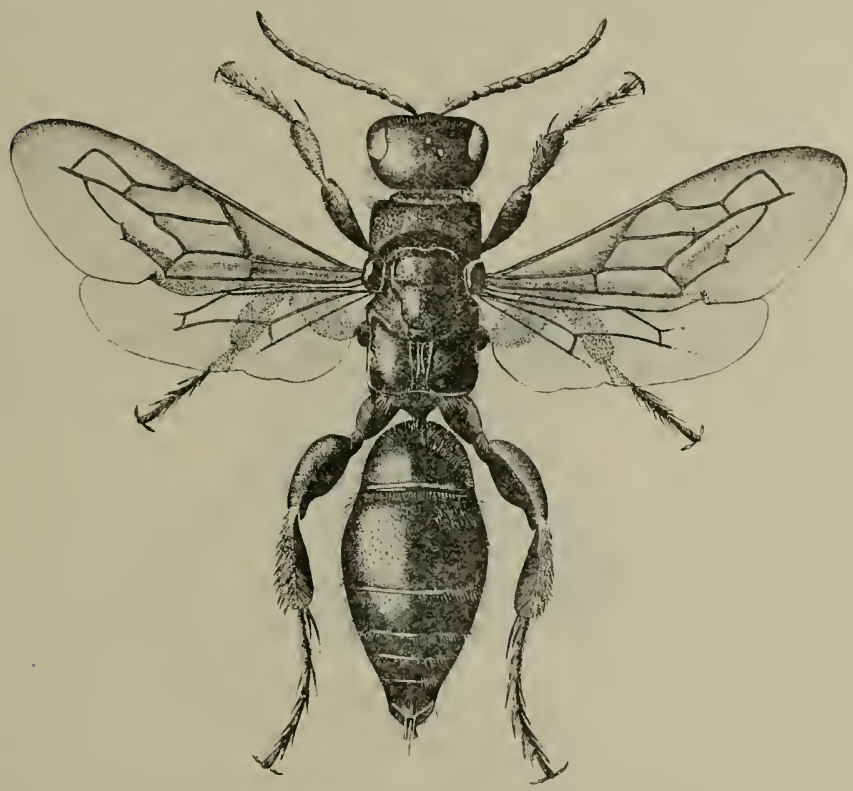

FiG. 1. Tiphia transversa Say, female.

taxonomy of this group has never been satisfactorily worked out, which fact accounts for much of the confusion in literature. They are entirely shining black with grayish hairs on the head, thorax, abdomen, and legs; the abdomen is very noticeably constricted between the first and second segments (Fig. 1); and the wings vary from transparent to brown, more or less deeply tinged. The males average about one-half inch in length and are more slender than the females, which average about three-fourths 
inch in length. The males are readily distinguished by the black, curved stylus or spine projecting upwards at the tip of the abdomen, sometimes, however, pressed to the body and more or less inconspicuous.

The egg, pure white when first laid, gradually becomes pale fleshcolor and finally cream-color or pale brown. It is elliptical in form, averaging for the species under discussion $1.25 \mathrm{~mm}$. in length and $.5 \mathrm{~mm}$. in thickness (Fig. 2).

Only the head of the larva protrudes when hatching begins (Fig. 3), but gradually the egg-shell splits longitudinally, exposing the body of the larva (Fig. 4). The body is pure glistening white and shows no characteristic markings, the segments being indistinct even in the mature larva (Fig. 5, and Pl. III, Fig. 1, 2).

The cocoon is oval, or egg-shaped, covered with soft, fluffy silk of a tan or golden brown color, and averages from 15 to $25 \mathrm{~mm}$. in length (Pl. III, Fig. 4, and Pl. IV, Fig. 8,9). Beneath the outer downy

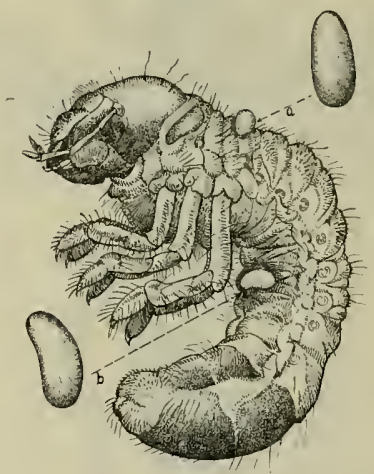

FIG, 2. White-grub showing position of Tiphia eggs; $a$. Tiphia punctrata Rob., $b, T$. 'transversa Say, and eggs much enlarged.

covering are several more compact and firmer layers, capable of protecting against unfavorable soil conditions, such as excessive moisture.

The method used by the writer in studying the details of the life of Tiphia is very simple, and the cage was an ordinary three-ounce tin salve box. Two grubs, put in opposite sides of each box, were covered with soil, and properly watered. These preparations were made in advance of the introduction of the parasite to enable the grubs to make cells, which would give more normal conditions for the Tiphia. A female Tiphia was then introduced into the box and the grubs were examined for eggs every few hours if very exact records of oviposition 
were desired. When a grub bearing an egg was found it was immediately transfered, with soil, to an ounce tin-box, which was then filled to the very top with soil so as to enable the grub to make a new cell. It was found that the egg was seldom displaced by this proceeding, whereas if the parasite was in the larval stage the grub would usually rub the larva off in forming a cell. Also for a grtb bearing a Tiphia larva, obtained
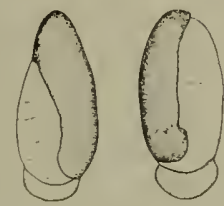

FIG. 3. Tiphia larvae recently hatched and part of body still concealed by egg-shell.

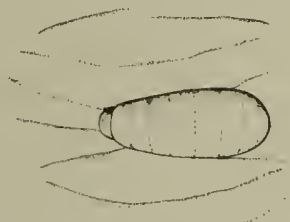

Fig. 4. Tiphia punctate Rob., larva a few days old.

in the field or elsewhere, if was safer, after placing it in a similar box, to use, instead of soil, a packing of loose, partially rotted, damp sphagnum moss, or rery loose muck soil. When the Tiphia cocoon had been completed it was transferred to a box containing an earthen cell. Each parasitized grub removed from the box containing the Tiphia adult was

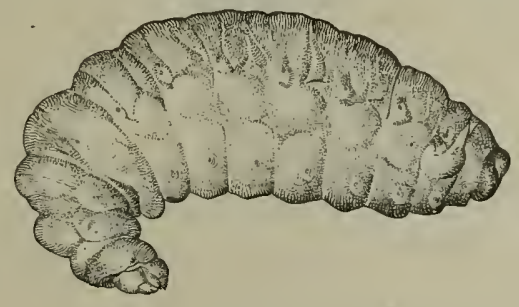

Fig. 5. Mature Tiphia larva.

replaced by a healthy grub and the Tiphia was fed honey water about every other day.*

The life histories of the four common species studied at Lafayette are similar in many respects, and are as follows: The black diggerwasps $T$. punctata and $T$. transzersa, and probably T. rulgaris also, issue from the cocoons during the summer, more often during June and July

* The writer takes this opportunity to acknowledge his indebtedness to Mr. D. G. Tower, who faithfully cared for the Tiphia experiments during the writer's absence August $15-30,1915$, and to Messrs. F. A. Fenton and S. L. Mason, who performed similar services in 1916 . 
( $T$. inomata earlier), feed on the Howers of such weeds as asters and parsnips or the honeydew of plant-lice (especially that of Aphis maidis Fitch), mate, and re-enter the ground to parasitize the common whitegrub. The grub is first paralyzed, the wasp stinging it on the under side of the first or second thoracic segment, and an egg is then laid on the dorsum of the thorax, the under side of the abdomen, or elsewhere, according to the species of Tiphia. The egg is firmly attached to the body of the grub by a glutinous secretion which is at first colorless but later darkens to brown. In the process of oviposition the wasp, after paralyzing the grub, encircles the body so that the tip of its abdomen touches that point on the body of the host to which the egg is to be attached. The wasp then moves the tip of its abdomen back and forth in a fold or crevice of the skin for several minutes, all the while spreading the secretion which serves to attach the egg securely to the body of the grub. Under natural conditions the Tiphia attacks the grub in its earthen cell, but when a grub is exposed on the surface of the soil, the wasp stings it and then proceeds to undermine and gradually to bury

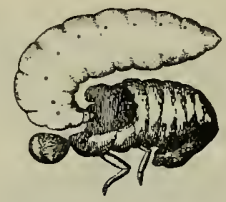

Fic. 6. Tiphia larva eating remains of grub after having killed it.

the grub before laying an egg on it. The egg having been laid the grub gradually returns to normal activity, the paralysis brought on by the sting of the wasp lasting only about an hour, or even less, and serving only to quiet the grub during the act of oviposition. Ordinarily but one egg is laid on a single grub, although in our cage experiments the wasp would in exceptional cases lay two or even three eggs on a single grub. That a second egg may be laid on a grub in the field if the first egg was dislodged is shown by the old egg-scars on grubs bearing an egg or larva, but we never have found a grub in the field which bore more than one egg or larva. Not infrequently the grub may molt soon after being parasitized, thus throwing off the egg or young larva, and once dislodged the parasite dies since it can not regain its position on the host. The egg hatches in four or five days, but in the beginning only the head protrudes. The larva immediately pierces the integument with its mandibles and begins to suck the body fitids, the grub apparently being unaware of its enemy. Within 5 or 6 hours the growth of the larva is sufficient to start an irregular longitudinal splitting of the egg-shell, and in 12 to 
24 hours the shell is split its entire length and the body of the parasitic larva is exposed (Fig. $t$ ). The larva remains affixed to the grub by the original egg-attachment (PI. III, Fig. 5, 6), and the host is more or less active until a day or two before the larva matures, growth up to this point being quite slow. At this critical time the grub succumbs to the loss of its body fluids, the larva molts, and apparently having developed stronger mouth-parts proceeds to devour the entire grub, learing only the chitinous head and portions of the shriveled hard skin (Fig. 6 and Pl. III, Fig. 1, 2). It was at first supposed that the Tiphia larva molted but once prior to spinning its cocoon and only a day or so before maturing, when it leaves the dorsal position on the host. However, an examination of the supposed skins arranged as leaflets beneath the larva and above the old egg-shell indicates that the larva molts five or ix times before pupation. The length of the larval stage, that is the tinie until the cocoon is begun, averages about two weeks, being shortest in the warmer months and longest in the cooler ones. There is also an inclication that the condition and activity of the grub has an influence on the growth of the larva.

After the larva has devoured its host it begins to spin the cocoon, first attaching loose threads of silk to all sides of the old grub-cell, fastening them more firmly at the small end of the cocoon with a "button" of silk (Pl. III, Fig. 3), and later spinning the inner layer, requiring from one to three days to complete the cocoon, judging from all external appearances. Unless the larva has a fairly uniform cell and one not too large it is unable to complete its cocoon, and will spin masses of silk at different places until it is exhausted and dies. Our observations indicate that most species remain in the cocoon over winter as larvae, although it is possible that other species, especially those issuing early in the spring, do pass the winter within cocoons as pupae or adults. The adults issue the following spring or summer, and in the latitude of Lafayette, Ind., all species of Tiphia have normally one annua] generation. Several exceptions have been observed in the case of $T$. punctata and $T$. transiersa in which the adults did not issue until the second season after spinning the cocoon.

\section{Tiphia PUNCTATA Rob.}

This is the commonest Tiphia observed by us, and according to the material contained in the National NIuseum and our own records, it occurs in Ontario, Canada, and in the states of New Hampshire, Massachusetts, Connecticut, Maryland, Virginia, Ohio, Indiana, Tennessee, Kentucky, Illinois, Wisconsin, South Dakota, Mississippi, Kansas, Texas, Louisiana, and New Mexico. Detailed studies of the habits and life history of this wasp were made at the Lafayette Laboratory in 1915, and the results are given herewith. Cocoons from which adults were obtained and used in these studies were collected in the following localities: Paxton, Ill., collected by G. N. Wolcott; Wellington, Kan., by E. 
G. Kelly; Hagerstown, Wolfsville and Reids, Md., by J. A. Hyslop, H. L. Parker, and W. E. Pennington; Berwyn and College Park, Md., by R. J. Kewley; Hadley, Massı, and Greenwood, Miss., by H. E. Smith; Central City, Neb., by J. W. Vieregg; Pukwana, S. Dak., by C. N. Ainslie; Wakenan, O., by W. B. Hall; Buda, Tex., by W. E. Davis; Tappahanmock, Va., by H. Fox; and Mt. Vernon, Oakwood, and Sheldon, Ill., Buck Creek, Frankfort, Huntingburg, Lafayette, Mt. Vernon, Switz City, and Washington, Ind., and Louisville, Ky., collected by members of the Lafayette Station staff.

The egg of $T$. punctata is invariably transversely placed on the dorsum of the thorax or first two abdominal segments (Fig. 2, a), most often on the third, or between the second and third, thoracic segments, usually just to one side of the median line in a fold of the skin, or, infrequently, on the median line. When laid to one side of the median line, the polar region, that is the anterior end of the egg, is invariably nearest the median line. The uniformity with which the female deposits its eggs is well illustrated by our experiments in 1915, in which eight wasps of this species laid a total of 205 eggs ('Table I), and in 1916, in which seventeen wasps, caged with white-grubs simply to determine the position of the eggs, laid eggs on the dorsum of the thorax or first abdominal segments invariably, and these 25 females as well as all of the progeny in the above-mentioned 1915 experiments (a total of 52 males) were determined by Mr. A. B. Gahan as T. punctata. Of the 69 records kept of sex of adults issuing from cocoons collected in the field, 25 were males and 44 were females. In our cage experiments the largest number of eggs laid by a single female of this species was 42 , with an average of 26 for the eight individuals observed, averaging a little more than one egg per day; but this is apparently below normal, and an examination of the ovary tubes of female wasps collected in the field indicates an egg capacity of 50 to $\% 5$. As will be noticed in Table $I$, the egg stage varies considerably in length, averaging about $127 \mathrm{~T} / 2$ hours, or slightly more than five days. The methods used by the Tiphia in paralyzing the grub and subsequently ovipositing on it, as well as other details of the life history common to the other species here discussed, have been described in a preceding paragraph. The length of the larval stage, that is till a start is made on the cocoon, varies from 9 to 21 days and averages 14.4 days (Table $\mathrm{I}$ ). This species almost invariably winters as a larva within the cocoon and has one annual generation. In our numerous experiments we have record of but one exception: an adult Tiphia punctata issuing July 1\%, 1916, from a cocoon collected at Tappahannock, Va., laid unfertilized eggs on grubs July 19-23, the larvae hatching, maturing, spinning cocoons, and issuing as adult male wasps by September 16 of the same year. In our experiments the adults issued from June 29 to September 6 , most often during the latter part of July or first of August, and specimens were collected in the field as early as June 20 and as late as September 12 . The adults live a maximum of 34 days in cages, and doubtless the normal life of the wasp 
62

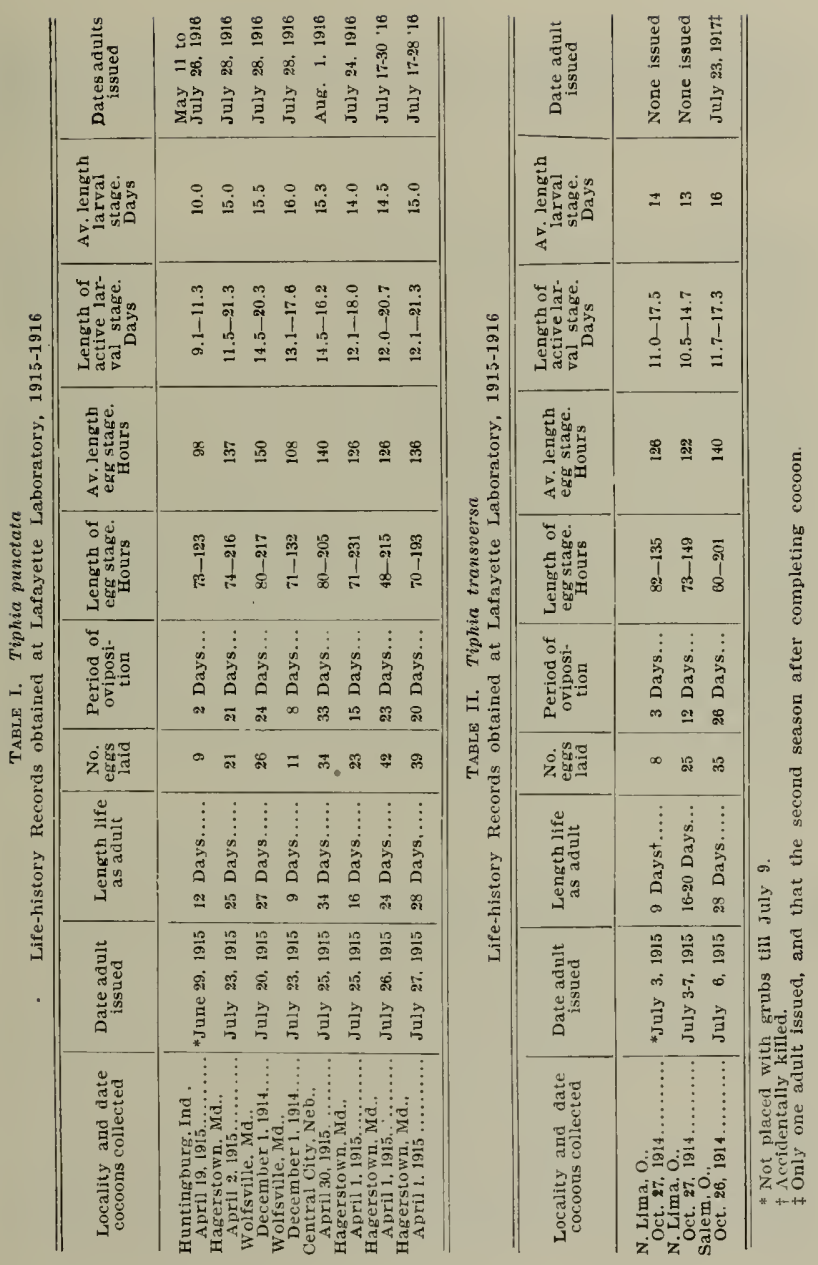


is a month or six weeks in the field. Table I gives the main points in the life history of eight individuals, but owing to the space it would require it seems impracticable to include the tables which we have drawn up showing all the details in the development of each individual larva.

\section{Tiphia transversa Say}

Although seemingly not so abundant as the species just discussed T. transz'ersa (Fig. 1) seems to be fairly general in its distribution in the northern states and is usually to be found in the same surroundings as that species. According to specimens determined by Gahan in the National Museum and in our own collection, it occurs in the states of Vermont, New Hampshire, New York, Connecticut Pennsylvania, Maryland, Virginia, Ohio, Indiana, Wisconsin, and Arkansas.

The habits of oviposition agree with those already described except in the position of the egg on the grub. Of the 90 eggs laid by seven individuals all were placed transversely on the under side of the abdomen in a groove or fold of the skin (Fig. $2, b$ ), usually just to one side of the median line and on segments $3,4,5$, or 6 , usually on 4 or 5 . When laid to one side of the median line the polar region of the egg invariably is nearest the median ventral line. The largest number of eggs laid by a single female was 35 , and as will be seen by the accompanying table (Table II) the date of emergence, length of egg stage, length of larval stage, etc., very closely approximate those of $T$. punctata. Dates of emergence in our breeding cages were from June 30 to August 21, and of those reared from cocoons collected in the field and recorded as to sex, three were males and eight females. Except for the position of the egg on the grub there is no noticeable or constant difference between the habits and life histories of the two species.

\section{Tiphia inornata Say}

This species, the largest of our Tiphias, is found, according to specimens in the National Museum and our own collection, in Canada, New Hampshire, Maryland, Ohio, Indiana, Illinois, and Wisconsin, and would therefore appear to be typically a northern species.

We have obtained eggs from only three individuals of inornata, but every one of the 22 eggs was laid on the under side of the thoracic or first abdominal segments, usually between the second and third thoracic segments and to one side of the median line, not infrequently relatively distant from the median line and between the legs. The egg period extended over a much longer time than for other species, that is, from 11 to 23 days, and this doubtless was due to the fact that the eggs were laid early in spring, when the temperatures were much lower. The adults of this species appear early in spring, as has already been stated, the dates of emergence ranging according to our records from April 8 to May 15, although we have found adults on wild parsnip flowers as 
late as June 26. Aside from the facts that the species appears early in the season, that the eggs are laid on the under side of the thorax and require a longer period for development, and that the stage in which it hibernates is doubtful, the life history of the species agrees with that of T. punctata.

\section{TIPHIA vUlgaris Rob.}

This species is known to occur in the states of New Hampshire, Massachusetts, New York, Virginia, Maryland, Ohio, Indiana, Michigan, Illinois. Wisconsin, South Dakota, Kansas, Mississippi, Louisiana. and Alabama.

We have not yet obtained eggs from vulgaris, but from the fact that it is a common species in Illinois and that we have found grubs bearing eggs on the dorsum of the abdomen conmon in that state, together with the fact that this is the only species known to parasitize the white-grub whose egg-laying habits are unknown, and that, conversely, the species laying eggs on the dorsum of the abdomen is the only one unknown, it is reasonable to believe that this species does lay its eggs on the dorsum of the abdomen near the anal end.

According to our meager records this species issues from May 8 to June 23 in the latitude of Indiana, but further data will probably show it to agree more nearly with punctata in the time of its appearance.

Four other species of Tiphia have been reared at the Lafayette Laboratory but we have no positive evidence of their host relations.

$T$. robcrtsoni Mall. was reared from cocoons collected at Wakenan, O., and Bells Valley, Va., and in the field where the former collections were made white-grubs were very abundant. Our dates of emergence are July 30 and 31 .

$T$. clypcata Rob. has been obtained by. us from Lafayette (Ind.) only, and the dates of collection were widely separated, some in May and others in October.

$T$. reticulata Mall. was reared by us but once, and the adult issued July 3 -from a cocoon collected by Mr. H. E. Smith at Agawam, Mass.

$T$. conformis Mall. was obtained from cocoons collected at Sheldon I11., Frankfort, Ind., and Richland. Mich., and the adults issued from July 24 to August 4 . The fields at Frankfort were well infested with Anomala grubs, while the fields at Sheldon and Richland containe a good infestation of Phyllophaga grubs, but positive evidence of their host relations was not secured.

\section{ENEMIES OF TIPHIA}

Three species of bombyliid flies representing two genera (Exoprosopa and Anthrax) have been reared from Tiphia cocoons. Of these, E. fascipennis Say, which was first recorded as a Tiphia parasite by Dr. S. A. Forbes $(26)$, is the most conmon in our rearings, although it would appear that none of the species are sufficiently abundant to lessen noticeably the value of Tiphia as a white-grub parasite. This 


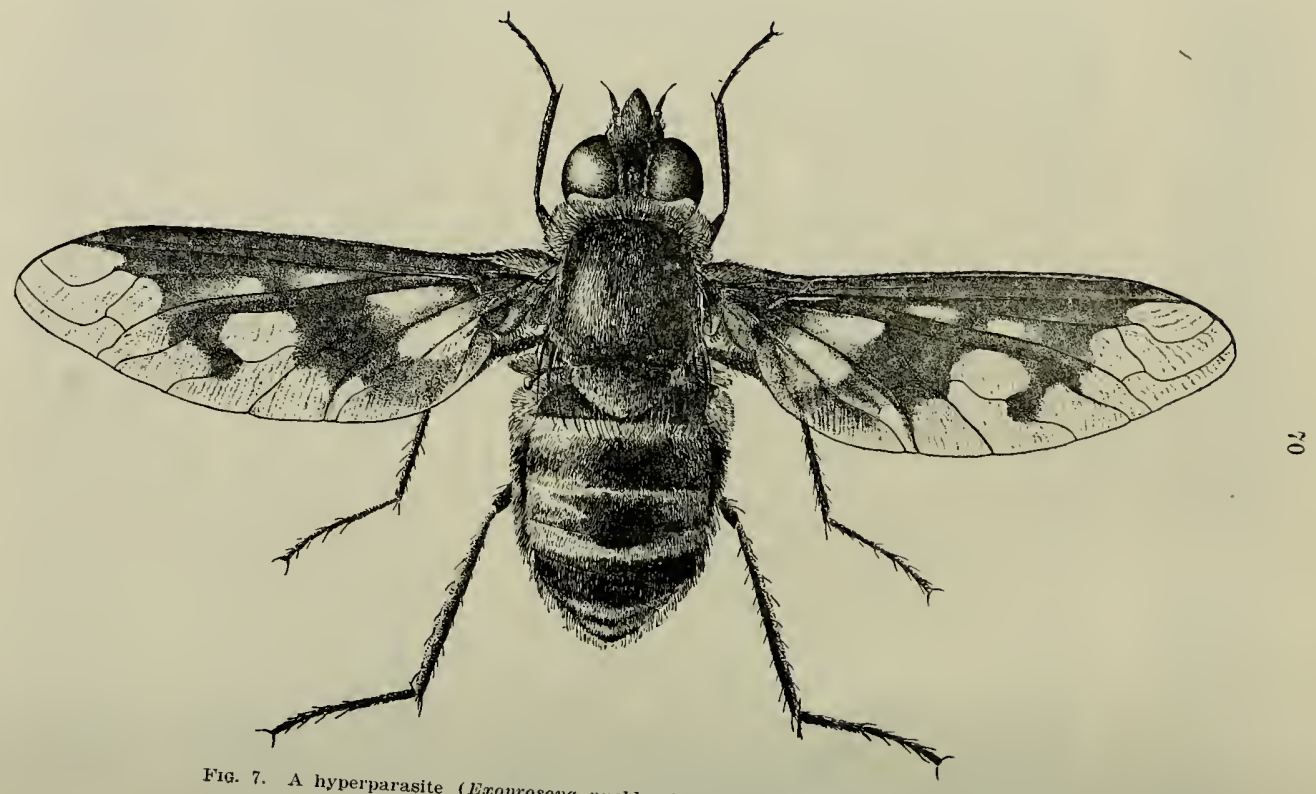

FiG. 7. A hyperparasite (Exoprosopa pueblensis Jaenn.)-a parasite of Tiphia. 
species has been reared at the Lafayette Laboratory from Tiphia cocoons collected in various parts of Illinois and Indiana, the adults issuing during the month of July. Mr. H. E. Smith obtained an adult July 7 , 1913, from Tiphia cocoons collected at Wellington, Kansas, and E. G. Kelly informs me that he has also reared it from the same locality and

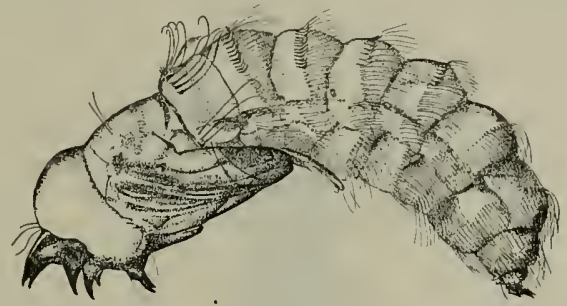

Fig. 8. Exoprosopa pueblensis Jaenn., pupa.

host. From the fact that Tiphia cocoons collected in the fall were infested with these flies (Exoprosopa fascipenis), it is certain that infestation originates in the summer or fall previous to emergence, and since they are incapable of entering the soil, and in view of the further

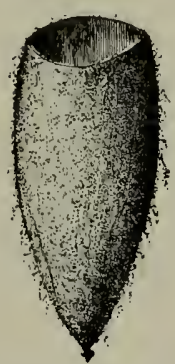

FIG. 9, Tiphia cocoon from which the hyperparasite (Exoprosopa) has issued.

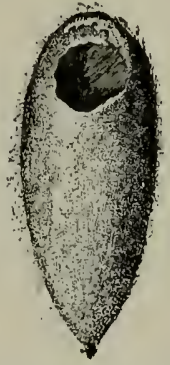

Fug. 10. Tiphia cocoon showing emergence hole made by the adult.

fact that they frequent flowers and feed on honeydew produced by aphids at the same time that the Tiphias are active, it is conceivable that the flies oviposit on the flowers or possibly directly on the Tiphias and that their eggs are carried away by the wasp and depositerl with its own egg on the Phyllophaga grub. 
Exoprosopa pueblensis Jaenn. (Walton and Cole det.), a species remarkably similar to fascipennis, was reared by E. G. Kelly from a Tiphra cocoon obtained at Wellington, Kansas (Fig. 7, 8).

Anthrax parvicornis Coq. was obtained by the writer in 1913 from Tiphia cocoons collected either at Rockford, I11., or Lafayette, Ind., the adult issuing previous to June 30 . The exit hole of this species, as well as that of the two species mentioned above, is made in the Tiphia cocoon

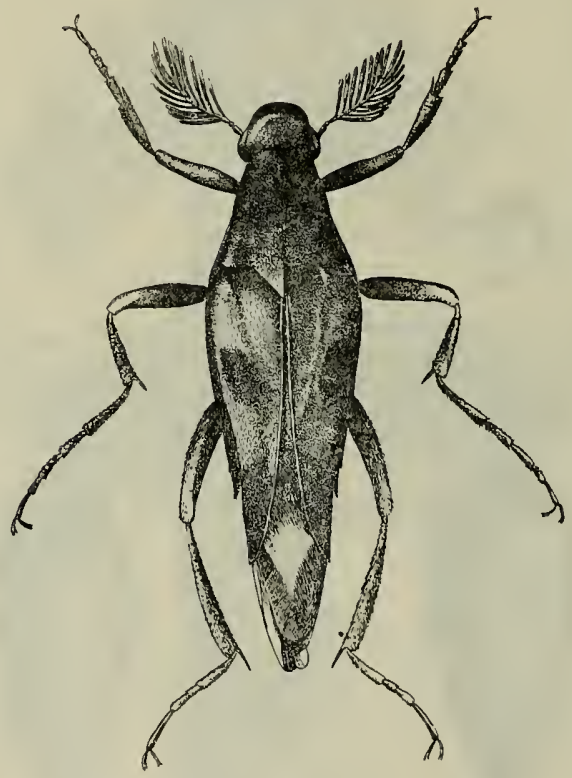

F1G. 11. A hyperparasite (Macrosiagon pectinatus Fabr.) - a parasite of Tiphia.

by cutting out a circular cap at the larger end of the cocoon, the cut heing as clean as though made with a sharp knife (Fig. 9, and Pl. III, Fig. $\tilde{r})$. It differs in this respect from the emergence hole made by the Tiphia adult, which is ragged, and although always made at the large end, is at one side of the tip (Fig. 10).

The interesting rhipiphorid beetle Macrosiagon pectinatus Fabr. (Fig. 11) was first recorded as having been reared from Tiphia cocoons 
by Dr. C. V. Kiley in $18: 4(59)$, and its parasitic habits have since been occasionally referred to in literature. We lave reared it from Tiphia cocoons collected in Illinois and Indiana, once from a cocoon collected by H. E. Smith at Hadley, Mass., and again from cocoons collected by J. A. Hyslop at Hagerstown, Md., and in all cases the beetles issued in July excepting the last collection-which issued May 15-and one from Mt. Vernon, 11l., which issued August 29. We have also reared a species determined by Mr. E. A. Schwarz as Macrosiagon 8-maculatus Gerst. from a mixed lot of Tiphia cocoons collected at Lafayette, Ind., and Rockford, 111., the adult in this case issuing July 1 ; and the same species was reared from the cocoons of a Ligyrus parasite, Campsomeris dorsata Fabr., by W. Nowell (53) in Barbados. Whether or not pectinatus and 8 -maculatus are distinct species is not agreed upon by systematists, the species being distinguished only by the elytral markings.

It is supposed that these rhipiphorid beetles are primary parasites of Tiphia, and it is probable that the egg is laid on or near flowers irequented by Tiphia adults, or possibly on the Tiphia itself, and that the egg or the recently hatched rhipiphorid larva becomes attached to the wasp and is in due course deposited on the Phyllophaga grub at the same time that the Tiphia deposits her own egg.

Lugger (46) speaks of a hymenopteron which is parasitic on Rhipiphorus, and we have occasionally collected cocoons behind the plow which were pierced with small holes resembling emergence holes of a small parasite.

It is interesting to note that the common English sparrow seems fond of Tiphia-at least in the 92 stomachs of this bird examined by Dr. Riley (61), 10 contained the remains of Tiphia adults.

\section{The Banded Digger-wasps (Elis spp.)}

Five species belonging to the genus Elis have been reared from cocoons collected in fields infested by white-grubs. Two of these, however, are doubtfully mentioned as parasites, no proof of their habits other than circumstantial evidence having been obtained. The cocoons are to be found more or less common behind the plow, especially in fields where white-grubs occur in abundance. The life history of only one species (E. 5-cincta) has been studied, but it seems likely that other species of Elis will agree with it in all essential details.

\section{Elis 5-Cincta Fabr.}

This scoliid wasp was first reported as a white-grub parasite in 1912, under the name Myzine sexcincta Fabr., by Flint and Sanders (22), and according to their observations it was found as abundant as Tiphia in certain parts of Illinois. Although the present writer has never found it so abundant it is common in some localities and no doubt is a very important aid in the natural control of white-grubs. Several species oi Elis are supposed to be parasitic on Phyllophaga grubs, but 5 -cincta is undoubtedly the most common where we have studied it, and 
has been collected by us in Wisconsin, Iowa, Illinois, Michigan, and Indiana. It has been reared by E. G. Kelly and H. E. Smith from cocoons collected at Wellington, Kansas; by W. R. McConnell and H. E. Smith from cocoons collected at Greenwood, Miss., by C. N. Ainslie from cocoons collected at Elk Point, S. Dak.; and by J. A. Hyslop from cocoons collected at Hagerstown, Md.

The habits of Elis differ noticeably from those of Tiphia, primarily in the fact that it permanently paralyzes the grub betore laying an egg. Briefly, the life history and habits are as follows: The adults issue in July and feed on the nectar of flowers, more especially sweet clover. At night the males rest on weeds and similar vegetation, the females entering the soil for oviposition. The method used by the wasp in attacking the grub is similar to that of Tiphia, but its sting causes permanent paralysis. After the grub is paralyzed, an egg, which hatches in about two days, is laid loosely on the under side of the abdomen of the grub. At first the larva consumes only the body fluid, as does Tiphia, but when nearly full-grown it eats the grub, leaving only the chitinized parts such as the head; it is therefore an ectoparasite throughout its life. Feeding rapidly, the larva consumes the grub and completes its growth in about 5 days, and requires from 1 to 2 days for the making of its cocoon-a total of only 8 or 9 days from the time the egg is laid until the cocoon is completed. Within the cocoon (P1. IV, Fig. 10, 11) it remains as a larva over winter, pupating in spring, and issuing as an adult wasp in July.

In 1914 notes on the life history of E. 5-cincta were obtained by confining numbers of Elis collected on sweet clover (Melilotus alba) in a 12-inch flower-pot cage containing white-grubs. The wasps were given honey water as well as sweet clover blossoms, and the grubs were examined every few days for eggs. Elis adults were first placed in this cage July $\%$, 1914, but eggs were not found until July 23 . According to our observations this species is not parthenogenetic, but in confinement unfertilized females do frequently sting and paralyze grubs. In this process the wasp wraps its abdomen about the first or second thoracic segment of the grub much as does Tiphia and stings the host on the ventrum of the thorax near the head. After a short struggle the grub becomes motionless and limp, in which condition it remains until devoured by the Elis larva or until it dies. We have kept grubs which have been "stung", but upon which the wasp failed to lay an egg, for over a month in an undecayed condition although to all appearances dead. The egg is white with a faint cream-tint, elliptical and slightly curved, $3 \mathrm{~mm}$. in length by $.8 \mathrm{~mm}$. in width. It is laid medially on the under side of the body (Fig. 12, and P1. V, Fig. 13), usually on the sixth or seventh abdominal segment, and not glued tightly to the body as is the Tiphia egg. Only one egg is laid on a single grub. Upon hatching, the larva immediately begins to feed on the body juices, the grub gradually shriveling from the loss. When almost grown, the parasite devours the grub, leaving only the chitinized parts, such as the head. 
The Elis larva is entirely white, including the head, the body shining and semitransparent. After completing its growth it commences at once to spin its cocoon, within which it remains over winter as such, pupating the following spring. The first egg observed was laid between $2: 00$ p. m., July 23 , and 10:45 a. m., July 25 , the date of oriposition probably being July 24 . The grub bearing this egg was placed in a oneounce tin box, and the egg hatched previous to $3: 00 \mathrm{p}$. m. July ?2, by which time the Elis larva was $6.7 \mathrm{~mm}$. in length and $2.5 \mathrm{~mm}$. in width (Pl. V, Fig. 14); at $10: 00$ a. m. July 28 it was $13.1 \mathrm{~mm}$. long and 5.2 mm. wide (Pl. V, Fig. 15) ; at 6:00 p. m. July 30, $19 \mathrm{~mm}$. long, and at $10: 00$ a. m. July $31,21 \mathrm{~mm}$. long (Pl. V. Fig. 16, 1\%). By this time the larva had nearly consumed the grub, finishing it by $5: 30 \mathrm{p}$. m. July 31 , when it measured $24 \mathrm{~mm}$. in length. At $6: 00 \mathrm{p}$. m. July 31 , it had commenced to spin its cocoon, which it completed by 10:00 a. m. August 2 . The larva died within the cocoon. In another case two paralyzed grubs were found in the cage at 2:30 p. m. July 23, each bearing an Elis larva on the under side of the body, one of which measured $7.6 \mathrm{~mm}$. in length and the other $10.5 \mathrm{~mm}$. The dates of egg-laying and hatching were not obtained. The larger one finished feeding and started its

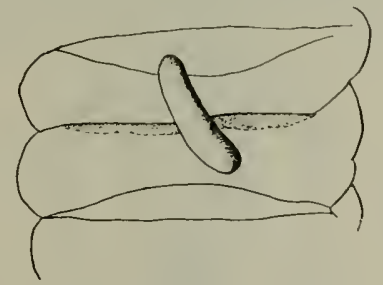

Fig. 12. Elis 5-cincta Fabr., egg on under side of 6 th and 7 th abdominal segments of white-grub.

cocoon by noon July 26 , and completed the cocoon previous to 5:00 p. m. July 28. From this an adult male Elis 5-cincta issued July 17,1915 , almost a year after the egg was laid. The smaller larva had nearly devoured the grub at noon of July 26 , and by 10:00 a. m. July $2 ?$ it had begun the framework of its cocoon, which it completed by 5:00 p. m. July 28. An adult male Elis 5-cincta issued from this cocoon a year later, July 8, 1915.

Our field observations corroborate the results obtained in cages, and they further indicate the months of July and August as the ones during which the adults are actively ovipositing. At Mt. Vernon, Ind., on August 28, 1916, recently made cocoons, larvae in act of spinning cocoons, and recently hatched larvae were obtained in one field. From cocoons collected by R. J. Kewley, D. G. Tower, and the writer, at 
Inglefield, Lafayette, Lewis, and Washington, Ind., and at Battle Creek. Mich., adults issued between June 28 and July 11 ; from cocoons collected by J. A. Hyslop and H. L. Parker at Hagerstown, AId., adults issued June 26 to June 29 ; and Mr. H. E. Smith obtained an adult as early as June is from a cocoon collected at Wellington, Kan.

In addition to the localities already given, E. 5-cincta has been collected by Mr. Ed. Foster at Abita Springs, La., during July and August according to Mr. G. N. Wolcott, and listed from Missouri by Phil. Rau, who observed the "sleeping" habits of the males (58), and from New Jersey.

The adults feed during the day on the nectar of sweet clover flowers almost exclusively. In one exceptional case R. J. Kewley and F. A. Fenton, of the Bureau of Entomology, found several individuals feeding on wild aster flowers. Collections were made on sweet clover flowers during the season of 1914 at Lafayette, Ind., by R. J. Kewley, A. F. Satterthwait, and the writer, and during 1915 by Kewley. The first collections were made July 9 and the last August 31, except in 1915, when one isolated collection was made as late as September 28. It is evident from these recorded observations, made at all hours of the day, that a majority of the females frequent flowers during the morning hours. Ordinarily the female wasps begin to appear about 8:00 a. m., or a little earlier, and until 10:00 a. m. scarcely a male can be found flying. Aiter 10:00 a. m. the males are found in increasing numbers, and the females in decreasing numbers, very few of the latter being found during the afternoon. Ninety-five per cent. were of one species, Elis 5-cincta, but occasionally specimens of E. atrizentris and E. interrupta were taken. At night the males have the habit of resting in "colonies" on the tops of weeds and other vegetation.

All of the species of Elis here considered are similar in general appearance and are well illustrated in Figure 13. The black thorax is more or less distinctly marked with yellow, the abdomen black and conspicuonsly marked with transverse yellow bands, and the wings are transparent and more or less shaded with brown. The sexes are readily distinguished, the male wasps having a more slender body and a prominent curved, hook-like stylus (Fig. 13,a) at the apex of the abdomen, which is absent in the female. The cocoon (PI. IV, Fig. 10, 11) is similar for all species, differing only in size. It is uniformly elongateelliptical, chocolate-brown, rather smooth, the inner lining thin and parchment-like, and these characters readily distinguish it from the ovate, woolly, paler brown Tiphia cocoons. The adult wasp issues by cutting a hole in one side near one end of the cocoon.

We have never reared parasites from Elis, but Mr. Otto Swezey (i2) reared a bombyliid (Chrysanthra.r fulrolivta Wied.; P1. IV, Fig. 12 ) and two mutillids (a male Mutilla castor Blake and a female $M$. fcrrugata Fabr.) from cocoons of E. scxcincta ( $=E$. 5-cincta) collected at Urbana, IIl. 


\section{ELIS ATRIVENTRIS Gahan}

This species (Fig. 13) was described and referred to as a parasite of Phyllophaga by Mr. A. B. Gahan (29), the specimen having been reared by Mr. C. N. Ainslie from cocoons collected at Elk Point, S. Dak., April 19. According to the original notes some of these cocoons bore Phyllophaga remains: but since several species (E. atriventris, E. 5-cincta, and E. illinoisensis) were reared from the lot it was not definitely shown that this species was parasitic. However, the writer has since reared $E$. atriventris from cocoons collected at Lafayette, Ind., which bore unmistakable remains of Phyllophaga grubs, and from

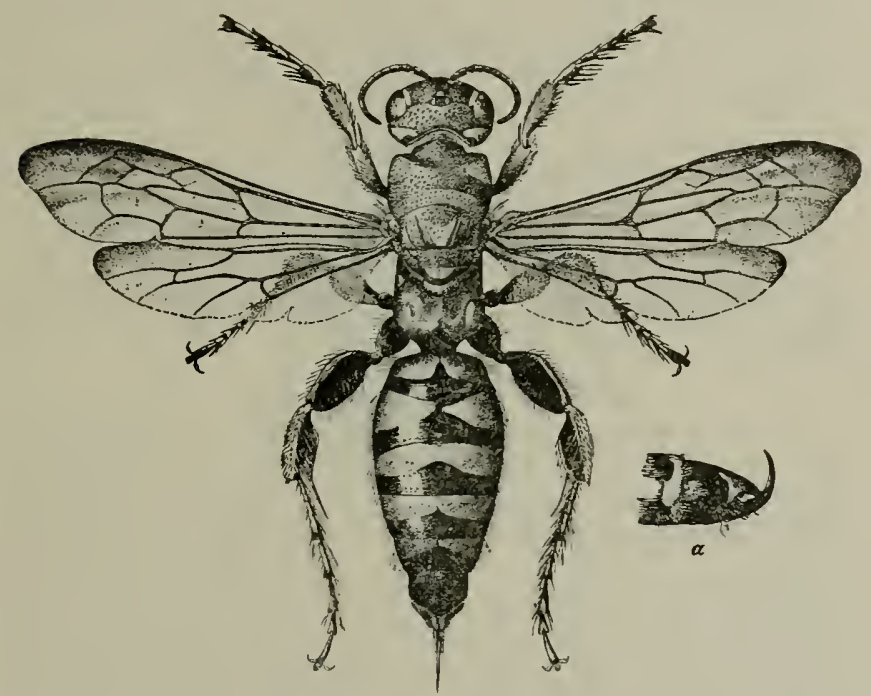

Fig. 13. Elis atriventris Gahan, female: $a$, lateral view of tip of abdomen of male, showing stylus.

cocoons, bearing like evidence, collected at Ashboro, Ind., which facts give us reasonable assurance of the truly parasitic habits of this species, The adults issue during July and are to be found in company with 5 -cincta feeding on such flowers as white sweet clover.

\section{Elis interRupta Say}

We have reared E. interrupta from cocoons collected at Hoopeston, I1l., and Lafayette, Ind., the adults issuing July 30 and September 6 , 
respectively. Inference of their parasitic habits is based on the remains of Phyllophaga grubs found attached to the above-mentioned cocoons collected at Lafayette. This species was also reared from cocoons collected behind the plow at Wellington, Kan., by Mr. H. E. Smith, the adult issuing July 5, 1913. The adults are to be found feeding on flowers of such roadside plants as the white sweet clover.

\section{ELIS OBSCURA Fabr.}

Although there is no direct evidence of the parasitic activities of this or the following species of Elis the fact that their cocoons are to be found in fields infested with white-grubs makes it quite likely that they will prove to have parasitic habits similar to those of the species already discussed. We have reared E. obscura from a cocoon collected by Mr. J. A. Hyslop at Hagerstown, Md., the adult issuing June 29, 1915 ; Mr. W. R. McConnell reared it from cocoons collected at Greenwood, Miss., the adults issuing May 30m 31, 1913; and Mr. Harrison E. Smith obtained several adults between June 3 and 17 from cocoons collected in plow furrows at the same place.

\section{ELIS ILLinoIsensis Dalla Torre}

Our records show this species to have been reared from cocoons collected behind the plow by Mr. C. N. Ainslie at Elk Point, S. Dak., and by Mr. H. E. Smith at Greenwood, Miss., the adults in the latter case issuing June $3-17,1914$. The status of this species in relation to white-grubs is the same as that of E. obscura.

\section{Tachinid and Dexitd Parasites}

Five species, two tachinids and three dexiids, have been reared from white-grubs of the genus Phyllophaga. Two of these species (Microphthalma disjuncta and Ptilodexia harpasa) are of considerable value in certain areas', and it appears that their occurrence in beneficial numbers depends largely on soil conditions which will enable the young larvae to easily penetrate the soil and so come in contact with their hosts. Two others of the five species, Microphthalma pruinosa and Ptilodexia abdominalis, can not be regarded as important enemies because of their rarity; and the remaining species (Myocera cremides?) is more often a parasite of Serica and grubs of similar habitat, than of Phyllophaga. Another dexiid (Prosena lacertosa v.d.W.), briefly treated in a subsequent paragraph, has been reported as a parasite of white-grubs in Mexico.

\section{Microphthalma disjuncta Wied.}

This species, under the name $M$. nigra, was first recorded as a parasite of white-grubs by Dr. S. A. Forbes (24) in 1891, who subsequently reared it from white-grubs (25 and 26), as has also the writer (16). Mr. D. W. Coquillett (13) reports it as reared by the late Theo. Pergande from a puparium found in the skin of a grub August 12, 1891, at Washington, D. C., the adult issuing October 15. 
The species has a wide distribution as shown by its reported occurrence in New Hampshire. Massachusetts, District of Columbia. New Jersey, Pennsylvania, Michigan, Indiana, Illinois, South Dakota. Kansas, California, Texas, Mississippi, and Georgia. We have reared it from grubs collected at Hagerstown, Md., by H. L. Parker; from Hadley, Mass., and Chelsea, Vt., collected by H. E. Smith; from Ercildoun,

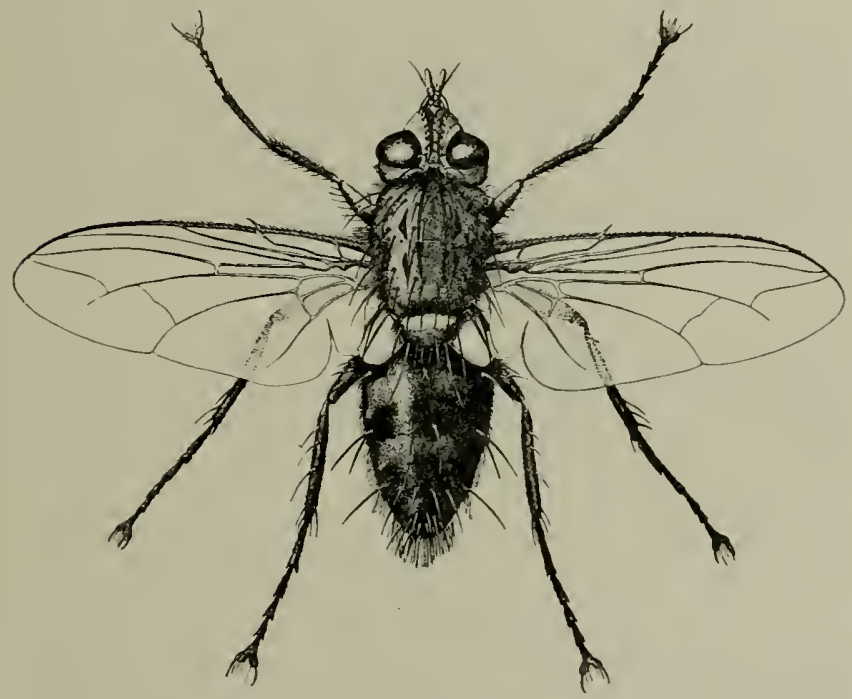

Fig. I4. Microphthalma disjuncta W“ied., male.

Pa., by J. C. Hamilton; from Crooks, S. Dak., by C. N. Ainslie; and from Lafayette and Lewis, Ind., Deford, Farmington, and Holly, Mich., and Swanton, O., by A. F. Satterthwait, D. G. Tower, R. J. Kewley, and the writer. Mr. H. E. Smith reared it from grubs collected at Broad Brook, Coun., in 1915, and from Greenwood, Miss., in 1914. Mr. Norman Criddle writes January 10,1918 , that he has reared $M$. disjuncta from white-grubs collected in Manitoba.

The adult is a rather large fly (Fig. 14, and Pl. VI, Fig. 22. 23), varying in length from 9 to 14 mm. The thorax is grayish above with 
more or less indistinct longitudinal black streaks; the abdomen, black with the anterior margin of each segment banded with grayish bloom, giving the appearance of alternate bands of gray and white; the entire body, including the head, set with conspicuous long hairs or bristles; and the transparent wings tinged with brown at the base and the wing veins faintly margined with brown. The flies are to be found from May till September, most often in June or July, occasionally at lights, and frequently on the ground in fields, especially corn fields. They are exceedingly alert and difficult to capture, although they will remain quiet and apparently unsuspecting until one approaches quite near, and when disturbed they usually light only a few feet ahead. Pairs have been observed in copula on the ground in corn fields in June and July. The female oviposits in the ground, probably in cracks, and the larva enters the grub, but just how this is effected has not been determined. Our observations show that oviposition occurs in fields either cultivated or in grass, probably more frequently in the former although our records are conflicting on this point. The small maggots remain within the grub until mature, passing the winter therein and completing their

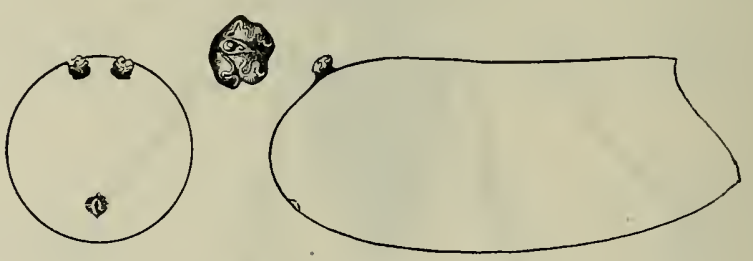

FIG. 15. Microphthalma disjuncta Wied., puparium : anal end, and one posterior spiracle.

growth the following spring. The infested grub feeds and acts normally until within a day or two of its death, which would indicate that the maggots feed entirely on the fatty tissues at first, not attacking the vital organs until nearly full-grown. The first indication of the presence of these parasites is the death of the grub and the coincident appearance of the anal end of the maggot through the skin of the grub, the conspicuous posterior spiracles showing prominently (P1. VI, Fig. 18). About the same time the grub begins to liquefy (P1. VI, Fig. 20), apparently melting away, and frequently the parasitic larva pupates within 24 hours from the time it is first noticed (Pl. VI, Fig. 19, 24).

Maggots were observed, in grubs collected in the field, as early as April 26 and until August 17, and the earliest and latest dates of pupation observed were on the same dates. Flies from caged material issued from May 24 to September 4, the length of the puparium period ranging 
from 15 to 43 days, apparently depending largely on temperature and quite likely also on moisture conditions. Although Phyllophaga grubs are more often attacked than others, we have reared this parasite also from grubs of Cotalpa lanigera, and it seems not unlikely that it may infest other large scarabaeid grubs that occur in cultivated fields. The maggot and puparium are distinguished from the related dexiids by the posterior spiracles, shown in Figure 15. In no case have we found more than two larvae infesting a single grub, the number usually being one to a grub.

As has been shown, $M$. disjuncta bas a wide range of distribution and in certain areas it undoubtedly has a marked influence on the abundance of grubs. In a collection of grubs taken at Farmington, Mich., June 12, 1916, over 25 per cent. showed disjuncta parasitisn. We have found it especially abundant in the eastern part of Michigan near Lake Huron, which would indicate a preference for, and an ability to live and seek its host advantageously in, sandy or sandy loam soils, as night be expected from our knowledge of its mode of life.

\section{Microphthalma pruinosa Coq.}

Eight Phyllophaga grubs were received at the Lafayette Station June 14, 1915, from Framingham, Mass., where they were reported to bc injuring pine and spruce seedlings. They were placed in individual one-ounce tin boxes, and on July 16 one was dead, and in the semiliquid remains the anal ends of two dipterous maggots protruded through the body-wall, exactly as had already been observed for the parasite Microphthalma disjuncta. By ten o'clock the following morning (July 17) one of the maggots had formed a puparium, which, however, was still uncolored. By 2:30 p. m. the puparium had taken on its natural reddish brown color, and between $2: 30$ and $5: 30 \mathrm{p}$. $\mathrm{m}$. the second maggot pupated. One adult, determined by W. R. Walton as $M$. pruinosa, issued August $2 \%$, but the record for the second adult which issued was lost. From the $\gamma$ remaining grubs \pm adults were obtained, all being Phyllophaga antia (=dubia, form insperata), and as the grubs had been carefully examined on receipt and no specific difference found, it is very probable that the species destroyed by this parasite was $P$. antria. This seems to have been the first recorded observation (16) concerning the host relations of this tachinid. We have since reared a single specimen of this species from a grub collected at Chelsea, Vt., Nay 31, 1916, by Mr. H. E. Smith. In this case the grub died July $\%$, which was coincident with the first appearance of the parasitic maggot, the adult fly issuing September 1 of the same year.

$M$. pruinosa seems to be widely, though sparsely, distributed, for it was described from specimens collected in New Mexico and Mexico, and Dr. Aldrich has a specimen which he collected at Brookings, S. Dak., in 1891 or 1892 . Apparently the species is of little economic importance in controlling white-grubs, owing to its scarcity. 
Ptilodexia harpasa Walk. (= = Tibialis Desv. of Coquillett and authors)*

This fly, first recorded as a white-grub parasite by the writer under the name tibialis (16), has a wide distribution, occurring, according to published records, in Nova Scotia and Ontario, Can.; and in New Hamp-

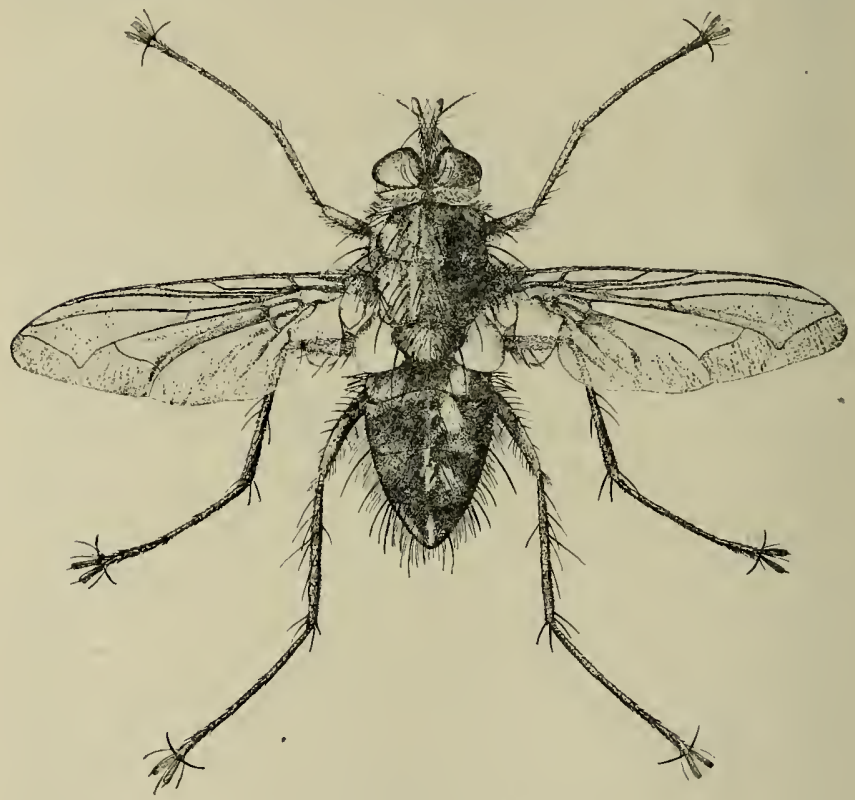

Fig. 16. Ptilodexia harpasa Walk., male.

shire, New Jersey, Minnesota, Texas, and New Mexico. We have reared it from Phyllophaga grubs collected by $\mathrm{H}$. E. Smith at Chelsea, $V^{t}$., and by the writer at Austin, Tex. Smith writes that he has reared

* Concerning the status of this species I quote the following note furnished by Dr. J. M. Aldrich:

"This snecies has been frequently referred to as Ptilodexia tibialis Desvoidy. which is evidently different as its describer placed it in a genus characterized by a petiolate apical cell. Austen, in Annals and Magazine of Natural History. Vol. XIX, y. 34t, reports from an examination of the type of harpasa that it is the same as tibirlis. Since lie evidently used the latter in the accepted but erroneous sense, his statement seems to justify the use of har'pasa for the present species.' 
it from grubs collected at Broad Brook and Orange. Conn.. and at Hadley, Mass., and Mr. N. Criddle writes of it January 10, 1918, as a white-grub parasite in Manitoba, Can. In addition we have reared it from grubs of Aphonus pyriformis collected by D. J. Caffrey at Las Vegas, New Mex., and by Caffrey and G. W. Barber at Maxwell, New Mex. It was also reared by W. E. Pennington from unknown scarabaeid larvae collected February 1\%, 1916, in a decayed stump at Gainesville, Fla., and one adult was reared, which issued March 2\%, 1916.

As with Microphthalma disjuncta, the grub is not seen to be parasitized until the parasitic larvae are practically full-grown. The habits of the larvae and their effect on the grub are like those of disjuncta except that there is not the conspicuous liquefying effect on the grub (Pl. VI, Fig. 21), previously mentioned for that species. Apparently
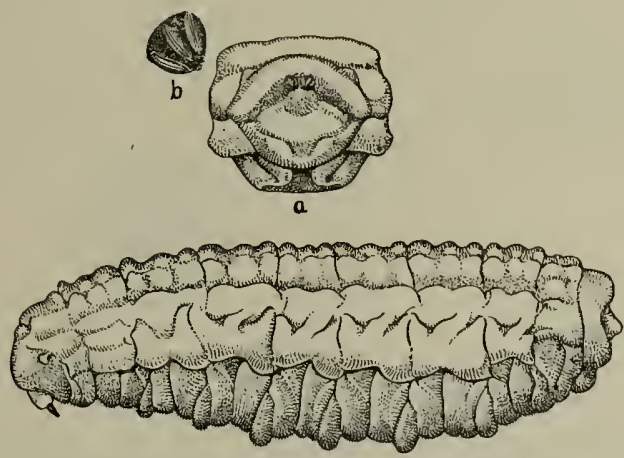

FIG. 17. Ptilodexia harpasa Walk., larva, lateral view: $a$, view of posterior 'end, showing spiracles; $b$, a spiracle much enlarged.

the eggs are laid in early fall and the small maggots enter the grub the same season, remaining within it over winter and completing their life cycle the following spring. From grubs collected at Chelsea, Vermont, May 8, maggots were observed from May 16 to 20 , forming the puparia usually a few days thereafter. From grubs collected at Austin, Texas, April 29, Ptilodexia larvae were first observed from May 18 to June 18. In these cases adult flies issued between June 11 and July 10, the puparium stage varying from 20 to 32 days. Grubs collected in New Mexico May 10 and 24 showed parasitisn from May 20 to July $\%$, while larvae from the same locality collected September $\tau$ and confined in indoor cages showed parasitic larvae from October $\%$ to February 23. The number of larvae infesting a single grub varies from 1 to $\gamma$ and the average from our 50 examples is $2.3+$. 
In all cases known to us where this species has attacked grubs the lercentage of infestation has been marked. For instance, in one lot of grubs collected by Mr. Smith at Chelsea, Vt., over 35 per cent. were infested by it, while more than 10 per cent. of our Austin, Tex., collection showed Ptilodexia parasitism, and over 45 per cent. of the Aphonus grubs collected by Caff rey and Barber at Maxwell, N. Mex., September $i, 1916$, were parasitized by this species. These few examples indicate the importance of this parasite in some sections.

The fly, which has rather remarkably long legs, is well shown in Figure 16, and Plate VII, Figure 25, and the larva and puparium, as well as the characteristic posterior spiracles, are shown in Figures 17 and 18 .

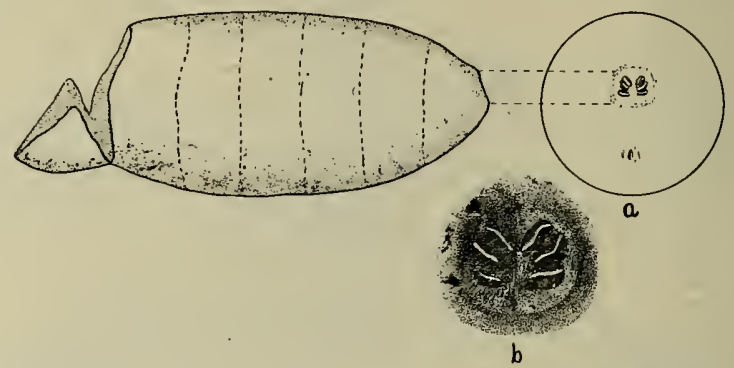

Fig 18. Ptilodexia harpasa Walk, puparium; $a$, posterior end, showing position of posterior spiracles; $b$, the spiracles, much enlarged.

\section{Ptilodexia AbDominalis Desv.}

This species and the following one are here recorded as parasites of Phyllophaga on the authority of Mr. Norman Criddle, whose notes are here given through the courtesy of Dr. C. Gordon Hewitt : P. abdominalis* was reared from larvae of Phyllophaga rugosa collected in Manitoba. The larvae entered the earth to pupate after killing the grubs as does $P$. harpasa, and the two examples reared, issued August 31 and September 1, 1915, respectively.

This dexiid has heretofore been recorded in literature only from Nova Scotia. $\dagger$

\section{Myocera CREMides Walk.? (of authors) $+\frac{+}{+}$}

Mr. Criddle reared a number of individuals of this species, six or more issuing July 7 from a grub of Phyllophaga anxia or P. nitida,

* Determined by J. D. Tothill.

$\dagger$ This species is listed in Aldrich's Catalogue (1) as Dexia abdominalis.

\$ Determined by C. W. Johnson. J. M. Aldrich informs us that this wide-spread species is known in collections under the name cremides, but that it does not agree with Walker's description of that species and is probably undescribed. 
others issuing July 15 and August \pm from grubs of Serica sp., and one August 9, from a grub of $P$. drakii. He writes me Jantary 21, 1918. that "Myocera cremides? appears to prefer Serica larvae and is evidently an inhabitant of semi-wooded areas."

The species is wide-spread, occurring according to published records and specimens in Aldrich's collection, from New Jersey to Oregon, the states and provinces represented including New Jersey (under the name simplex in "New Jersey Insects"), Indiana, Iowa, Minnesota, Manitoba, S. Dakota, Idaho, and Oregon.

Prosena (Mochlosoma) lacertosa v. d. Wulp

This dexiid fly was found by Mr. C. H. T. Townsend during August 1909 , abundant in pastures near Colonia Garcia, Mlexico, principally on flowers of Rudbeckia. The flies, according to Mr. Townsend, were at the time of his visit issuing in great numbers from puparia in the soil, and the pastures in the vicinity were heavily infested with whitegrubs, from which it was concluded that $P$. laccrtosa is parasitic upon white-grubs $(\%)$. This inference is probably correct, and this species is apparently of considerable importance in Mexico as a white-grub enemy.

\section{Hymenopterous Enemies Recorded}

\section{Ophion Bifoveolatum Brullé}

This large, slender-bodied, reddish brown ichneumon-fly (Pl. VII, Fig. 30), which is distributed throughout the United States, has not been reared by us from larvae actually found attacking grubs. The first reference to this insect as an enemy of white-grubs seems to have been made by Dr. C. V. Riley (63), who based his record on observations made by Prof. F. M. Webster at Lafayette, Ind. Professor Webster obtained a number of specimens of this species from a cage containing white-grubs, and this appears to be the only reason for the conclusions published by Riley. Dr. S. A. Forbes (26) records it as a parasite of grubs, basing his conclusions on his office notes-which he kindly permits the writer to publish here. The first note is as follows: "Leroy, Ill., Sept. 1, 1906. E. O. G. Kelly. Ophion cocoon found in a sod field with part of the skin and head of Lachnostcrna grub enwrapped with cocoon. To rear adult. April 2\%, 190\%. Ophion adult [later determined as $O$. bifoveolatum] has emerged, pinned it with cocoon as accessions No. 3.368. Davis." Another note furnished by Dr. Forbes reads- "Ophion sp., Kelly. Mackinaw, Ill., 10/06. Sending to insectary."

The adults issue for the most part during April, and the larva is probably ectoparasitic, as is Tiphia. The larva becomes full-grown and spins its cocoon previous to August, passing the winter within the cocoon, which is dull brownish, frequently darker at the extremities, smooth and uniform in thickness at the ends as is the cocoon of Elis, but mucl shorter, measuring about half an inch in length and a quarter of an inch in thickness. 
Our official records contain the following note which probably refers to this species: Mr. A. F. Satterthwait collected a Lachnosterna bearing a Tiphia-like larva, in a field at Nortonville, Ky., August 6, 1915, and when received at Lafayette the following day the grub was dead and the larva spinning its cocoon. The cocoon proved to be that of an ichneumonid, but was accidentally lost before the adult issued. It is not unlikely that it was an Ophion cocoon.

If this species is a parasite of Phyllophaga only, one would expect to find it common in infested fields, since the adults are said to be common and wide-spread. The above questionable record is the only avaitable Bureau record bearing on this point, notwithstanding the fact that we have collected and reared thousands of grubs from all parts of the United States.

\section{Pelecinus Polyturator Dru.}

Only one record of this species as a white-grub parasite has been published, and this by Dr. S. A. Forbes (25), who in 1892 reared it from a Phyllophaga grub obtained at Champaign, Ill., May 9, the adult issuing August 26 of the same year. There seems to be no question as to the authenticity of the record notwithstanding the fact that this still stands as the only observation on the larval history of Pelecinus.

The female of this parasite is quite remarkable. The entire body is jet-black, and the abdomen an inch and a half long (P1. VII, Fig. 29), differing markedly from the male, which lacks the long, slender-jointed abdomen.

In 1914 and 1915 female specimens of $P$. polyturator were found rather common by $R$. J. Kewley in an isolated area four miles north of Lafayette, Ind., although not a single male was observed. July 31, 1914, he collected nine females; August 3, eight; August 8, fifteen; August 27, three; September 5, one; and September 6, eleven. The following year (1915) he collected two on August 26 ; three August 31 ; and ten September 8 , none being found after this date although weekly searches were made, nor were we able to find the species in any other area. The locality in question is a wooded glen along the Wabash River and mostly shady and cool. The bottom is rather swampy from the overflow of a smali stream of spring water, and is matted with grass, water plants, and other vegetation. The specimens mentioned above were collected in flight or resting on foliage. The females are slow fliers and travel close to the ground, seeming to prefer sunny spots near stagnant water, and never resting long in one spot.

The females collected were placed in cages covering pots containing white-grubs. On two occasions a Pelecinus was seen with the abdomen inserted to the thorax in a crack in the ground. In one case the insect withdrew the abdomen half a minute after being observed, and then spent several minutes in cleaning the body with the feet. In the other case the abdomen was thrust into the soil several times within two or three minutes. Probably the females oviposited in the soil, which was not examined at the time, but no Pelecinus was reared, nor could we 
find traces of Pelecinus parasitism when the contents of the cage were examined the following spring.

\section{The Tawny Bee-fly (Sparixopoluts fulves Wiecl.)}

The larva of this bee-fly was first reported as an enemy of whitegrubs in $190 \%$ by Dr. Forbes (26), his assistant, Mr. E. P. Taylor, having found it attached to the back of a Phyllophaga grul, at Elliott, [11., August 25, 1904. Whether it is ectoparasitic as are the Tiphias or predaceous as are the Asilidae seems not to have been positively determined. Probably it is in a sense parasitic for, owing to its small size, it carr and probably does obtain all the necessary, food from a single grub; lut since the fly can not enter the soil to lay its eggs directly on the grub,

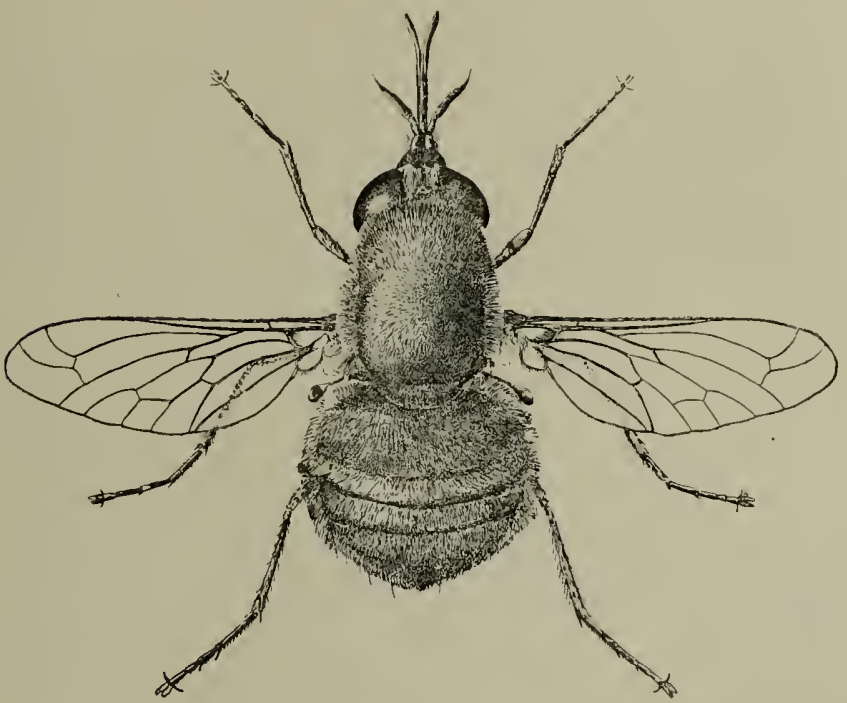

Fig. 19. Sparnopolius fulvus Wied., femalo.

and probably, therefore, oviposits in a crack of the ground, the larva upon hatching from the egg must search through the earth for its host, the grub, and is to this extent predaceous.

This species has been reported from such widely separated localities as New Jersey, New Mexico, and Illinois, an! although a common insect it is probably not of prime importance as an enemy of the white-grubs. 
The adult is to be found on vegetation and on flowers in August and September. It is nearly as large as the common house-fly, but unlike the latter it is covered with erect, yellow, fur-like hair which gives it a look more like that of a bee than of a fly, and hence it has received the common name of bee-fly (Fig. 19). The pupa, which has been described in detail by J. R. Malloch $(4 \%)$, is fully exposed and not enclosed within the last larval skin as are muscoid Diptera such as the louse-fly, and it superficially resembles a small asilid pupa.

At Galena, Ill., September 22, 191\%, this fly was very abundant on the flowers of common roadside Helianthus, and a spider (Phidippus audax Hentz, det. C. R. Shoemaker) was seen to capture one of the flies as the latter alighted on the flowers.

\section{Hairworms (Mermithidae)}

Among the several thousand grubs reared at the Lafayette Laboratory but four have shown parasitism by hairworms. These worms are specifically indeterminable, from our material, but belong to the genus Mermis, and apparently we have two species: one from grubs collected at Pensacola, Fla., by R. N. Wilson, and the other from grubs collected at Oakland, Md., by W. E. Pennington. The Florida grubs, collected March 1, 1915, were received at Lafayette March 3, and placed in individual 1-ounce tin boxes. Harch 16 one grub was dead and found to be infested with Mermis, and ten days later a second dead and blackened grub was noticed, and Mermis infestation was found to be the cause of its death. The worms were comparatively small, measuring about 6 inclies in length, and several occurred in each grub. In the second case mentioned, one grub among a lot collected at Oakland, Md., November 10,1915 , and received at Lafayette a few days later, was found dead November 15 and infested with two worms of the genus Mermis. These were of cream-yellow color and noticeably larger than those infesting the Florida grubs, measuring 11.3 and 12.5 inches in length respectively (PI. XI; Fig. 45). Dr. Henty Fox, of the Bureau of Entomology, also reared a mermithid from a Phyllophaga grub, obtained at Tappahannock, Va., May 1, 1915, the dead grub and worm being noticed July 13 of the same year. More recently (October 1, 191\%), among a collection of white-grubs made by Mr. C. F. Turner at Lexington, Mich., September $26,191 \%$, we found one live grub infested with these worms, which were visible throngh the integument of the dorsum of the last abdominal segment. These were photographed (see P1. XI, Fig. 43, 44) and the live specimens were sent to $\mathrm{Dr}$. N. A. Cobb, who determined the parasite as a mermithid.

According to published observations Mermis has been recorded from a large number of insect hosts, and we have ourselves frequently obtained it from cutworms. The worms, on becoming mature, leave the host, their maturity being usually coincident with the death of the host, and remain in the soil probably for several months in a semi-quiescent condition, during which period the sexual organs are developed. Mois- 
ture is necessary for the growth and development of the worms although it has been assumed that the eggs might bear more or less desiccation. The eggs of the species parasitic on white-grubs are no doubt laid in the soil and it is to be presumed that the worms enter the body of the grub after hatching in the soil, although it is likewise possible that infestation occurs from eggs or young larvae taken into the body with food.

\section{A West Indian Grub-Parasite (Campsomeris dorsata Fabr.)}

Mr. D. L. Van Dine has reported Campsomeris dorsata as a parasite of a white grub in Porto Rico ( $i r$ and $i s$ ), and more recently Mr. Wr. Nowell has given an extensive account of this species (53) as a parasite of Ligyrus tumulosus Burm., which may have been the grub referred to by Van Dine. Whether it may also be a parasite of Phyllophaga or Phytalis grubs is not known, but Van Dine's record seems to justify mention of it as a possibility. Ligyrus tumulosus larvae live in manure and in soil rich in decaying matter, and the wasp in oviposition completely paralyzes the grub and then lays an egg on the under surface of the body, the egg being deposited on end and at right angles to the axis of the body. The green June-beetle [Cotinus (Allorlina) nitida] has similar habits, and according to our observations its common parasite (Scolia dubia Say) attacks the grub and oviposits almost exactly as does $C$. dorsata. The wasps of Campsomeris are like Elis adults in frequenting flowers, and in the sleeping habits of the males.

\section{Predaceous insect-enemies of larva}

\section{RobBer-Flies (ASILIDAE)}

The larvae of several species of robber-flics (Asilidae) are predaceous on Phyllophaga grubs, and doubtless many other species of this group of flies will be found similarly active and nuch more beneficial in destroying underground insects than has been supposed.

The adult robber-flies are more or less beneficial in that they prey upon other insects, and we have seen one species (Proctacanthus milbcrtii) capture and destroy such active and hard-backed beetles as tiger-beetles (Cicindela I2-guttata Dej.). They are often considered harmful and are frequently referred to as "bee-killers" because of their habit of catching honey-bees.

Larvae of Asilidae belonging to six genera (Promachus, Erax, Deromyia, Asilus, Ceraturgus, and Proctacanthus) are treated in the following pages as actual, probable, or possible predaceous enemies of white-grubs, the last two classes being included mainly for the benefit of other workers who may have opportunity for further observation of their habits. 
Promachus vertebratus Say

This important eneny of white-grubs is known to occur in Michigan, Indiana, Wisconsin, Illinois, Iowa, Minnesota, South Dakota, and Washington.

According to our observations the larva of $P$. vertebratus is the most beneficial of the asilids known to attack white-grubs. It is very common in certain parts of Wisconsin and Michigan where the common white-grub is a serious pest. The writer has several times seen the larva of this species attacking grubs in the field, most frequently in the summer or early fall, when the grubs have become more or less inactive and have made cells preparatory to pupation. It makes a small entrancehole into the cell and through this attacks the grub, withdrawing if necessary to escape its mandibles. After it has weakened the grub, or if this is in the inactive prepupal or pupal stage, the predator may enter the cell and leisurely consume its host. In the summer and fall of 1914 we found large numbers of the empty pupal exuviae of this fly protruding half their length or more from the ground in fields at Baraboo

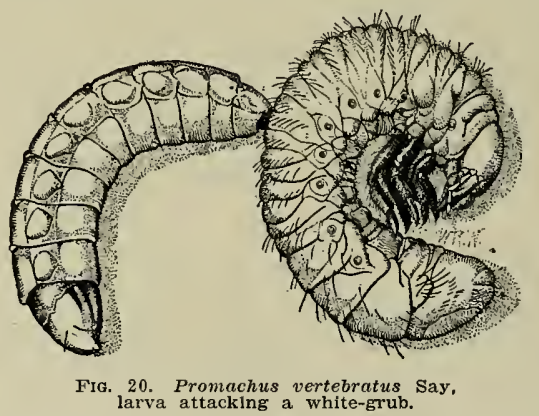

and Madison, Wis., and at Richland, Mich., where grubs had been destructive in 1912 and the adult beetles of that brood had issued in the spring of 1914 .

The life cycle has not been completely worked out, but from the facts that we have kept larvae in confinement for two years and that larvae of one size and pupal exuviae are found common in the same locality only every three years, it is probable that the cycle is three years, as Dr. Felt has found to be the case with $P$. fitchii. The larva is pure creamy-white, smooth, cylindrical, and tapering at the extremities. It very closely resembles the larva of Erax, and is shown in Figure 20. In feeding, it punctures the host with its sharp mandibles and, inserting its head in the small opening, sucks the body fluids. This and the other 
asilid larvae differ noticeably from tabanid larvae in their feeding habits, the latter using their mandibles to tear the skin of the host and being exceedingly quick in their operations, while the asilids are slower in their movements and pierce their host by a puncture rather than by a cut or tear. The pupal form, and especially the brown chitinized spines and the stigmal spots, can be seen beneath the larval skin several hours

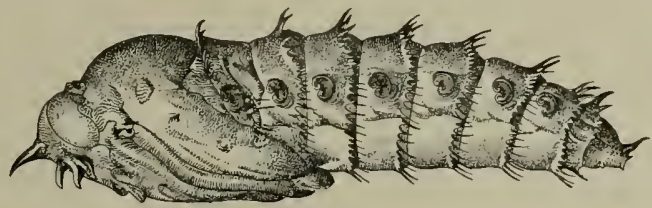

FIG. 21. Promachus vertebratus Say, pupa.

before pupation actually takes place. As the larval skin splits the pupa rapidly emerges, requiring less than a minute and a half to complete its exit. The head and body segments of the pupa are well armed with rigid spines (Fig. 21) which it uses to advantage in pushing itself to the surface of the soil just before the emergence of the imago. Pupation occurs, according to our records, from May 26 to July 18 , and the adults issue from June 15 to August 18, the pupal period varying from 19 days, in rare instances, to 39 days, with an average from 55 examples of $32 .+$

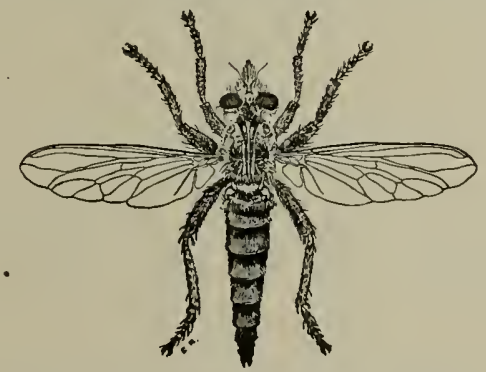

FIG. 22. Promachus vertebratus Say, male.

days. Of the 59 adults reared and recorded as to sex, 29 were males and 30 females. The fly is very characteristically shown in Figure 22 and in Plate VII, Figure 26. The female lays its whitish, elliptical eggs in fall in cracks in the soil or in little earthen cavities which the female makes, usually several eggs being laid together. The larvae upon hatching search the soil for food, probably feeding at first on small 
soft-bodied insects and possibly also on earthworms. We have no record of the number of grubs which a single vertebratus larva may destroy but it is doubtless several, possibly many, and it undoubtedly ranks as one of the most important natural enemies of the conmon white-grub.

\section{Promachus fitchil O. S.}

According to Aldrich's catalogue (1) this species has been recorded as occurring in Missouri, Kansas, Nebraska, Florida, and Connecticut, and we have reared it from larvae collected in the grub-infested areas near Richland, Mich., and Madison, Wis. The larva of $P$. fitchii was first reported as predaceous on grubs by Dr. E. P. Felt (18) who found it very abundant in fields heavily infested with white-grubs in New York, in some cases outnumbering the grubs. According to Dr. Felt's observations the larvae live in the ground at least two years, and it is believed that they have a three-year life cycle-which would correspond exactly with the length of the life cycle of the more injurious species of Phyllophaga in New York-a very important factor where only one destructive brood occurs every three years. There is little doubt from Dr. Felt's notes that this larva is as destructive to grubs in New York as is $P$. vertebratus in the central states.

According to our rearing records pupation occurs usually in June, although occasionally in May, and in every case the pupal period was almost exactly 30 days in length.

We are unable to distinguish the larvae of fitchii from those of vertebratus although the mature larvae of the latter are much the larger. The pupae are likewise very similar, but are separable according to $\mathrm{Mr}$. J. R. Malloch (48). The adult of fitchii (Pl. VII, Fig. 2\%) is smaller than that of zertebratus and quite unlike it in appearance, the body of the former being covered, sparsely in parts, with golden hair.

\section{Promachus bastardi Macq.}

This species, which has not been seen by us, occurs in the Eastern States, and Mr. H. E. Smith states that the larvae are predaceous on Phyllophaga grubs in confinement cages. From this observation and from the known habits of the closely related species already mentioned, there is little doubt that $P$. bastardii attacks grubs under normal fieldconditions.

\section{Erax maculatus Macq.}

(Syn. E. interruptus Macq., and E. latcralis Macq.)

Of the several species of Erax known to attack white-grubs, maculatus is the most common and beneficial. While following the plow near Greenwood, Miss., in March and April, 1914, Mr. H. E. Smith found many asilid larvae, the fields being in all cases infested with white-grubs to a greater or less degree; and in one or two instances the larvae were seen feeding on grubs. In confinement the larvae, which were believed to be of a single species, readily attacked grubs, usually puncturing the host on the dorsum near the head, but sometimes at 
other points. Frequently they partially entered the opening thus made, all the while sucking the body fluids, sometimes feeding until nothing but the shriveled grub-skin remained. Several adults issued, all prior to August 21, 1914, but only one was preserved. This proved to be $E$. maculatus. A larva of this species which we obtained December 11 , 1915, at Louisville, Ky., in sod ground heavily infested with Phyllophaga and Cotinus (Allorhina) grubs, pupated July 29-August 3, 1916, and the adult issued September 2. Mr. George G. Ainslie collected three larvae of this species while following a plow at Fellsmere, Fla., March 25,1914 , and placed them all in one box. When examined a month later only one remained, the others having apparently been killed and eaten by the survivor. This larva, which was received at the Lafayette Laboratory May 1, issued as an adult August 6, 1914." The larva (Fig. 23) of this species has been previously recorded by E. S. G. Titus ( 13 ) as predaceous on Ligyrus grubs in Louisiana. It attacks a grub as does
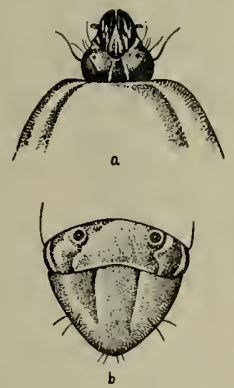

FIg. 23. Head (a) and anal segment $(b)$ of Erax maculatus Macq., larva.

Promachus zertebratus, which is shown in Figure 20 in its typical position when attacking a grub.

From our data the life cycle appears to be one year, the winter always being passed in the larval stage, pupation occurring in July and August, and the adult fly (Fig. 2t) issuing during August and early September.

The species is distributed from Pennsylvania to Central America, but seens to be more typically a species of the southern United States.

According to Titus ( 13$)$, the adults of E. maculatus are predaceous on adult tabanids the larvae of which are, predaceous on white-grubs.

\section{ERAX AEstuANS Linn.}

This species is included as a possible enemy of white-grubs from the fact that it was collected in a field infested with them and does attack Phyllophaga grubs in confinement. A single specimen was reared by 
us from a larva received from Mr. G. G. Becker, obtained at Hot Springs, Ark., August 19, 1916. It pupated September $\hat{\imath}$ and issued as an adult October 22, 1916.

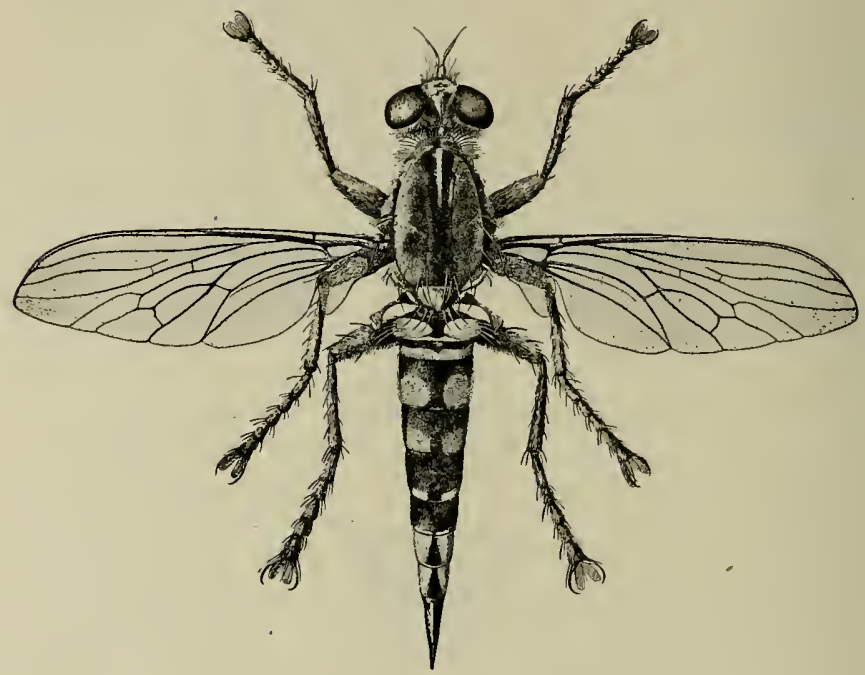

Fig. 24. Erax maculatus Macq., female.

Erax cinerascens Bellardi (Syn. E. albibarbis Macq.)

Mr. E. G. Kelly reared two adults of this species from larvae collected at Wellington, Kan., March 11, 1911, in fields infested by whitegrubs. The larvae pupated between May 6 and 19, 1911, and adults issued about June 11. No evidence of their' predaceous habits was obtained. We have also reared this species from a larva obtained by the writer September 29,1916, in a field heavily infested by grubs at Rockton, Ill. The larva pupated between May 31 and June $\%, 191 \%$, and issued as an adult July \%, $191 \%$.

\section{Deromyia Winthemi Wied.}

June 28, 1915, Dr. Henry Fox, while following a plow in a wheat stubble field at Tappahannock, Va., found a larva of this species "crawling over and apparently feeding on a Lachnosterna pupa." The larva 
and pupa were placed together in a tin-box cage, and July 3 he saw the maggot feeding on the pupa. By July 6 nothing but the shriveled pupal skin of the grub remained and the larva appeared to be noticeably larger. It pupated previous to July 16, and the adult which issued between August 6 and 9 was determined by W. R. Walton as Deromyia zeinthemi (Pl. VIII, Fig. 31). Dr. Fox also reared this asilid from a pupa found in the soil at Tappahannock, Va., June 28, 1915, the adult issuing July 16,1915 .

\section{Deromyta discolor Loew}

Mr. Harrison E. Smith reared this species at Wellington, Kan., July 1, 1913, from a larva picked up behind the plow March 11, 1913, and Mr. J. A. Hyslop collected larvae behind the plow at Wolfsville, Md., May 2, 1913, from which he obtained pupae June 13 and 14 and two adults of D. discolor July 10 and 11, respectively. Aside from the fact that the fields were infested with white-grubs, there is no evidence that they were predaceous.

\section{DEROMYIA UMBRINA Loew}

Although we have no positive proof that this or the preceding species is predaceous on white-grubs, the fact that they are found in fields infested with grubs and the further fact that the very closely related
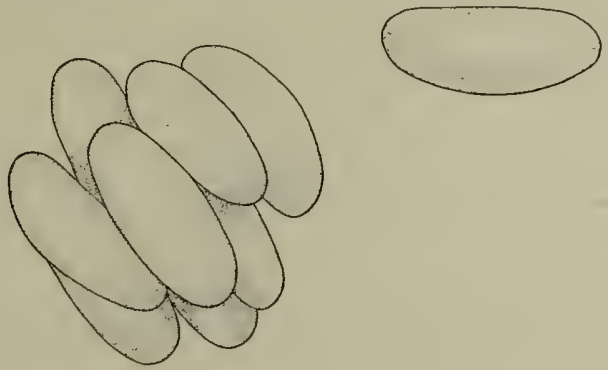

Fic. 25. Deromyia unbrina Loew, eggs, much enlarged.

species $D$. winthemi is known to attack them are indicative of their habits, and the notes herewith given seen pertinent.

A nale and female $D$. umbrina collected at Lafayette, Ind., by Mr. R. J. Kewley, were placed in a chimney cage at $6: 00 \mathrm{p}$. m., August 1, 1914, and by $3: 30$ p. m., August 4, 93 eggs were laid, the female dying the following day. The eggs were laid singly or in groups of 2 to 13 , a few on the surface, but most of them in the soil at various depths up to $3 / 8$ inch, the majority about $1 / 4$ inch deep. Some were placed in cracks in the dirt, and others in little cavities made by the female. The egg 
is cream-colored, elliptical, slightly curved, 1.8 to $1.9 \mathrm{~mm}$. in length by $.8 \mathrm{~mm}$. in width (Fig. 25, and Pl. IX, Fig. 38). The eggs hatched between $1: 00 \mathrm{p}$. m. August 11 and $1: 00 \mathrm{p}$. m. August 12, but none of the larvae were reared to maturity.

Asilus paropus Walk.

We have reared this species from larvae collected by the writer at Montford, Wis, October 3, 1914, in a field heavily infested by whitegrubs, obtaining from the larvae thus collected 3 adults which issued June 9,12 , and $\approx 6,1915$, respectively ; also from a larva taken at Lancaster, Wis., September 27, 1916, which pupated between May 24 and 31, $191 \%$, and issued as an adult June 22, 191\%. Although the reared specimens were not noticed feeding on grubs in the field, another specimen, supposed to be of the same species, was actually seen attacking a grub. This species has also been reared at this station from a larva obtained by Mr. A. F. Satterthwait in a grub-infested field at North Lima, Ohio, October 27, 1914, the adult in this instance issuing June 14, 1915. Mr. H. E. Smith has seen larvae of this species attack grubs in confinement, but, because of their small size, he believes they are more actively predaceous on smaller larvae, such as Anomala and Macrodactylus.

- The life history of $A$. paropus is unknown, although it probably does not vary greatly from that of Promachus. The pupal stage, according to our observations, varies in length from 17 to 28 days, the adult, a small, slender fly, issuing in June.

The species is sparsely but generally distributed in the northern United States east of the Mississippi.

Asilus LeCYThus Walk.

We are not familiar with this species, which resembles $A$. paropus, but Mr. H. E. Smith reports it, in a letter, as predaceous on Phyllophaga grubs in confinement. He believes, however, that like $A$. paropus it is more often predaceous on smaller grubs of the genera Anomala and Macrodactylus.

\section{Ceraturgus cruciatus Say}

Our collection records show that the larva of this species occurs in fields heavily infested with white-grubs. One larva taken by C. F. Turner at Richland, Mich., April 18, 191\%, pupated between May 3 and 10 and issued as an adult June 5, $191 \%$.

\section{Proctacanthus milbertil Macq.}

The larva of this rather common Proctacanthus has not been seen attacking white-grubs but has been taken in fields heavily infested with them at Richland, Mich., by C. F. Turner, and at New Carlisle, Ind., by the writer. At the former place it was found in company with grubs of Promachus vertcbratus. Our rather meager data indicite that it has a two- or three-year cycle, the larva pupating in July (July 13-23 according to our records), and the adults issuing about six weeks later (August 24 to September 6). 


\section{Coexomyia pallidi Say}

According to J. R. Malloch (49) the larva of Coenomyia pallida Say (=ferruginea, American authors) has been seen to feed on whitegrubs in confinement. This larva was taken in a field near Chicago where grubs were common, and another at DuQuoin, Ill., "in company with larvae of Asilidae and probably fed also upon white-grubs."

\section{Horse-Flies (TABaxidae)}

Two species of tabanid larvae (Tabanus atratus Fabr, and $T$. sulcifrons Macq.) are predaceous on Phyllophaga grubs, and further researches will no doubt show the like for other species.

The Autuma Horse-fly (Tabanes sulcifrons Macq.)

$T$. sulcifrons seens to be commoner than $T$. atratus. It has been reared from larvae collected in plow furrows at Greenwood, Miss., by Mr. J. M. Langston in February, March, and April, 1916. Some of these larvae pupated at the Lafayette Laboratory between August $\gamma$ and September 4, adults issuing August 23 to September 27, while others passed the winter in the larval stage. The length of the larval stage was 16 days for those pupating in August to 23 days for those pupating the first of September. The length of the life cycle probably is normally one year, but no doubt scarcity of food or unfavorable soil conditions may prolong this period, as is indicated in our experiments. Larvae apparently belonging to this species but which died before maturing,

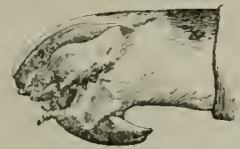

FIG. 26. Tabanus sulcifrons Macr. head of larva, showing sharp mandibles extruded.

were collected in plow furrows by Mr. E. G. Kelly at Wellington, Kan. Others were received from Mr. R. J. Kewley, who collected the' ? while following the plow at College Park, Md.. April 20, 1916. These continued as larvae until fall of the following year, pupating in August, $191 \%$, and issuing as adults nearly a month thereafter. We also reared a single adult from a larva taken by G. G. Ainslie June 2t, 191t, at Caney Springs, Tenn., the larva pupating between Attgust 18 and 24 and the adult issuing September 14, 1914.

In all cases the larvae were collected in fields containing white-grubs, and their predaceous activities in relation to Phyllophaga and Cyclocephala grubs in confinement were conclusively shown. On coming into contact with the soft body of the grub the larva thrusts its mandibles into the skin, and into the opening thus made the head is inserted, and the body fluids are consumed. The action of the mandibles is very 
peculiar and interesting. They are quite sharp, strong, slightly curved, and carried in a groove along the dorsal lateral side of the head when not in use. When in action they are rapidly thrust outwards and downwards (Fig. 26), the two generally working in unison and literally tearing the skin of the prey. Sometimes this operation is repeated several times and at different points on the body of the grub before any attempt at feeding is made. The writer has had his hand so severely punctured by the mandibles that itching or stinging lasted for several hours. In our

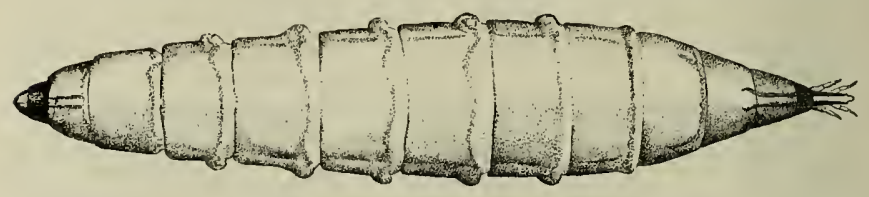

FiG. 27. Tabanus sulcifrons Macq., larva.

tiu boxes the host grub sometimes prepared a cell, and the tabanid larva often made an entrance to the cell just large enough for its head and the fore part of its body, thus enabling it to withdraw, if necessary, to a safe distance from the grub. This strategy is also frequently adopted by asilid larvae. The Tabanus larvae can crawl about and penetrate the earth quite freely. They prefer moist places. They no doubt feed on various soft-bodied underground insects, and probably on earthworms also. This species and $T$. atratus can pass long periods without fooda capacity frequent among predaceous larvae living under similar conditions.

The adult is one of the common horse-flies and is often so. abundant as to be a serious stock pest. It is distributed from New Jersey to Louisiana and Missotri. It is of large size, varying in length from 17 to 20 nnm.; the large compound eyes are typical of the family; the under surface of the thorax is densely covered with a grayish pubescence, the upper surface with alternate black and grayish brown longitudinal mark-

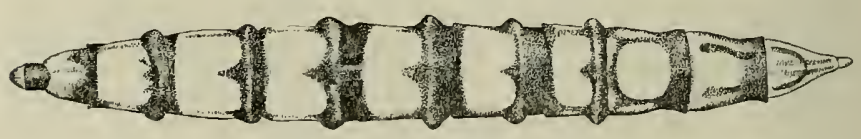

Fig. 28, Tabanus atrutus Fabr., larva.

ings; the dorsum of the abdomen is reddish brown, with yellowish white triangles on segments two to five; the wings are transparent, with certain areas of the veins margined with brown (P1. IX, Fig. 34, 35). The eggs have not been described, but they are probably dull-colored and laid in masses like those of related species. The larva (Fig. 2\%) of this species, which measures about $30 \mathrm{~mm}$. in length when full-grown, is glossy, semitransparent white with delicate, almost microscopic, longi- 
tudinal striae. By these characters alone it is readily distinguished from the larva of $T$. atratus, which is marked with black (Fig. 28), and from the asilid larvae Erax and Promachus, which are waxy white or creamcolor. Likewise the anal end of Tabanus bears a retractile fleshy protuberance or breathing tube (Fig. 29), and each abdominal segment bears six ventrally placed fleshy tubercles, the upper one on each side along the lateral line being the most conspicuous, and those on the last

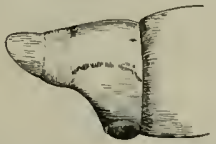

FIG. 29. Tabanus suleifrons Macq. anal end of larva.

two or three segments only faintly indicated. The asilid larvae lack these characters, the anal end being more or less pointed and the body smooth. The chitinous head is elongate and slender, brownish, and freely retractile (Fig. 26). The dull brown pupa (P1. IX, Fig. 36) is slender, rather uniform in thickness throughout its entire length, curved, and is not armed with conspicuous spines as are the asilid pupae. The reader is referred to papers by Hine $(36,37,38)$ and Hart $(34)$ for more complete descriptions of this and the following species, and for particulars concerning their habits.

\section{The Black Horse-fly (Tabanus atratus Fabr.)}

Our observations on the habits and activities of this species are confined to one rearing record made from a larva obtained by Mr. A. F. Satterthwait near Linton, Ind., May 3, 1916. The larva was found along the drainage-ditch edge of a corn field where acute injury by wireworms and cutworms occurred in 1914. The tract in which this larva was found is a reclaimed swamp, covered with water much of the time until a few years ago and only the past season or two sufficiently drained for cultivation. The larva was placed in an ounce tin-box and there freely attacked and ate grubs of Phyllophaga and Cyclocephala. It pupated between August 24 and 29 and the mature fly issued September 11, 1916. Its feeding habits differed in no way from those described for sulcifrons.

The adult (P1. VIII, Fig. 32: PI. IX, Fig. 33) is one of the commoner species of horse-flies, known as the black horse-fly or breeze-fly, and is distributed from southern Canada to Mexico, east of the Rocky Mountains. It is conspicuous because of its very large size, measuring about $24 \mathrm{~mm}$. in length. The large eyes are typical of the familv, the thorax and abdomen are black and covered with a thin whitish bloom, and the wings are black at the base to dusky or brownish transparent at the apex. According to Mr. Chas. A. Hart, who carefully described the various stages (34), the eggs are dark brown, subcylindrical, about 
$2.5 \mathrm{~mm}$. long, with the surface minutely rugose. They are laid in masses (as illustrated in Plate IX, Figure 37, single masses containing as many as 500 eggs) on rushes and the like over water or wet ground. The larva is larger than that of the species just described, and at the connection of each segment is a broad blackish band which widens on the sides to form a broken lateral longitudinal blackish line. Otherwise it resembles $T$. sulcifrons. It is well illustrated by Figure 28. The pupa is similar to that of sulcifrons but is slightly larger (Pl. VIII. Fig. 32).

According to Walsh and other authors this species is semiaquatic and feeds on water-snails, and probably also on various soft-bodied insects and earthworms.

Mr. Hart obtained a hymenopterous parasite (Phanurus tabanivorus Ashm.) from the eggs of T. atratus (Pl. IX, Fig. 3\%, and P1. X, Fig. 39) and the same parasite has been reared from this host in Ohio and Louisiana by Prof. J. S. Hine (38). Another parasite, obtained by Mr. F. C. Bishopp from tabanid eggs collected in Texas, has been recently described by A. A. Girault as Phanurus cmersoni (31). These two species of Phanurus are the only parasites known to attack the tabanids in any stage.

\section{Coleoptera (Carabidae)}

Carabid larvae are always to be found in abundance in fields which are being plowed, and occasionally they have been seen in unusual abundance in those heavily infested with white-grubs. While the evidence

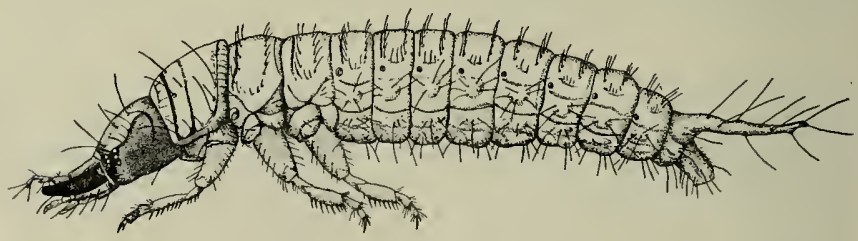

Fig. 29a. Harpalus pennsylvanicus Dej., larva, much enlarged.

in their favor in these cases is largely circumstantial, it is very probable that they are often predaceous on grubs, and much more beneficial than at present supposed.

While following the plow at Victoria, Texas, February 18, 1916, Mr. J. D. Mitchell found carabid larvae abundant in a grub-infested field; in fact they were nearly twice as numerous as the grubs, and the adults which we reared from the larvae sent to us, proved to be our common Harpalus pennsylvanicus Dej. (Schwarz det.). In our underground hreeding-cages larvae and adults of $H$. pennsylvanicus (Pl. VII, Fig. 28) and Amara sp. have been found abundant, with evidence of their predaceous activities, and in the cages it appeared that the adult beetles as well as the larvae (Fig. 29a) attack the grubs. In the field this 
species is the most frequent and doubtless the most beneficial of all the carabids, although we also find the larvae of $H$. caliginosus Fabr, quite common in grub-infested fields.

An interesting observation on the predaceous habits of these larvae was made by Mr. H. E. Smith at Wellington, Kan., April 4, 1913. A carabid larva picked up behind the plow and placed with a Phyllophaga grub immediately attacked it, piercing the skin with its mandibles but not tearing it, making only a small opening through which the body fluids were obtained. The grub thus attacked died in about three hours, after most of the body fluids had been consumed. The carabid died before maturing.

The carabid adults, commonly termed ground-beetles, have been frequently observed feeding on adult May-beetles. Mr. C. M. Packard saw an adult Calosoma calidum Fabr. in the act of attacking a live Maybeetle at Hagerstown, Md., April 21, 1914. The beetle worked its head beneath the elytron of its prey and bit into the soft part of the abdomen. a method usually practiced by these insects. Mr. Packard observed at the same time a Harpalus caliginosus eating the remains of a dead Phyllophaga, there being no proof, however, that it was responsible for the death of the beetle. Mr. W. L. Taliferrio saw at College Park, Md., May 8,1893 , a C . calidum feeding on the viscera of a live Phyllophaga adult through a hole in the abdomen, and the writer has made similar observations at Lafayette, Ind. We have also seen Calosoma scrutator Fabr. eating a live May-beetle beneath an electric light. Dr. Forbes (25) mentions finding a carabid beetle (Chlacnius tomcntosus Say) clinging to a Phyllophaga beetle and feeding upon its viscera, partly drawn out of the wound, and Dr. Riley (60) saw Calosoma lugubre attacking May-beetles beneath street lights.

An interesting parasite of Harpalus pennsylaanicus (?) larvae was found by the writer at Mendon, Mich., September 11, 1916. In the field, which was being plowed, carabid larvae and adult $H$. pennsylvanicus (Schwarz det.) were exceedingly numerous, and two larvae were found parasitized by a hymenopteron. Both were rigid, as though attacked by an Isaria fungus, and to one the naked pupa of the parasite vas attached. The other showed the parasite larva just issuing. The larva when mature, issues from the anal end of the host, and, remaining attached, it pupates as illustrated (Pl. XV, Fig. 61). The adult of this parasite was not obtained.

\section{Miscellaneous Insects sometimes Predatory}

Dr. Forbes (26) records an observation made by E. G. Kelly, who found three yellow coarctate meloid larvae with the remains of whitegrubs attached, the natural supposition being that they had been feeding on the grubs; and this is quite probable since it is a well-known fact that meloid larvae, the inmature stages of the destructive blister-beetles, feed on grasshoppers' eggs and the immature forms of certain other insects. 
Ants can not be considered predaceous enemies of white-grubs, but in our cages it is evident that they have been responsible for the death of grubs and pupae. It is doubtful if healthy grubs are ever attacked by them under normal conditions, but we have seen them attacking grubs alnost immediately after being exposed by removing a piece of infested sod. The ants in the cases mentioned above, were Lasius niger Linn., var. americanus Emery.

According to Mr. E. G. Smyth, Mr. T. H. Jones reared larvae of an elaterid (Pyrophorus luminosus Ill.) upon Phyllophaga larvae in confinement, and adults were taken from soil in a cane field in Porto Rico where the white-grubs had been present in numbers, the latter fact indicating that the predaceous activity observed by $\mathrm{Mr}$. Jones in the cages is a normal habit of the larvae under field conditions. Mr. J. A. Hyslop has found these larvae similarly active toward white-grubs in tin-box cages.

Crickets may also prey upon white-grubs, as was noticed by the writer at Cascade, Iowa, September 24, 191\%. While following the plow in a sod field heavily infested with the 1917 brood of grubs, two species of crickets (Gryllus assimilis Fabr. and Nemobius fasciatus, var. vittatus De G., Caudell det.) were seen to attack the young grubs as these were exposed by the plow. The crickets were quite numerous, the small Nemobius probably the more common, and after attacking the grub they would feed on the fluids issuing from the wounds.

\section{Mites as Enemies of Phyllophaga Larvae}

Mites, determined by Mr. Nathan Banks as Rhizoglyphus phylloxcrac Riley, have frequently been found infesting grubs in the field and are a constant cause of trouble in our breeding cages. They firmly attach themselves to their host, and if not removed will frequently kill the grub. While we have never found then as destructive in the field as in our tinbox cages, nevertheless there is little doubt that they do sometimes weaken or even kill grubs under natural conditions (55). The same species has been collected on white-grubs by Mr. J. A. Hyslop at Hagerstown, Md., and by Dr. Henry Fox at Tappahannock, Va. It is widespread, our records showing its occurrence in the United States from Massachusetts to Texas. Its normal food appears to be decaying vegetable and animal matter.

A pale whitish species, Tyroglyphus armipes Bks. (Banks det.). was found infesting white-grubs collected at Austin, Tex.; and a third species attacking them, which Mr. Banks determined as Parasitus sp., was collected by Mr. C. N. Ainslie at Springville, Utah, and at Elk Point, S. Dak.

The adult May-beetles are also sometimes infested by mites, and specimens referred to $\mathrm{Mr}$. Banks were determined as belonging to the family Parasitidae (Gamasidae) and to the genus Uropoda. All of the mites we have collected on May-beetles are in the nymphal migratory stages, in which they attach themselves to the beetles as a means of car. 
riage, and are probably neither parasitic nor preslaceous. When a suitable breeding ground is reached the mites drop and transform, and begin to feed on bacterial and fungous growths.

\section{Parasites of the beetle}

\section{Ortalid Flies}

(Pyrgota undata Wied. and P. valida Harris)

Our earliest record of $P$. undata as a parasite of Pliyllophaga adults was made by Prof. F. M. Webster, who reared it in the spring of $1 \times 91$ from beetles collected at Lafayette, Ind., and the first published recoril is that of Dr. Forbes in 1907 (26). P. valida was first reared and recorded by the writer in 1913 (15), and we have since reared it many times.

The life histories of the two species are substantially alike. The beetles are attacked only at night while they are feeding, or in flight, the Pyrgota fly alighting on the back of the beetle, which if feeding is

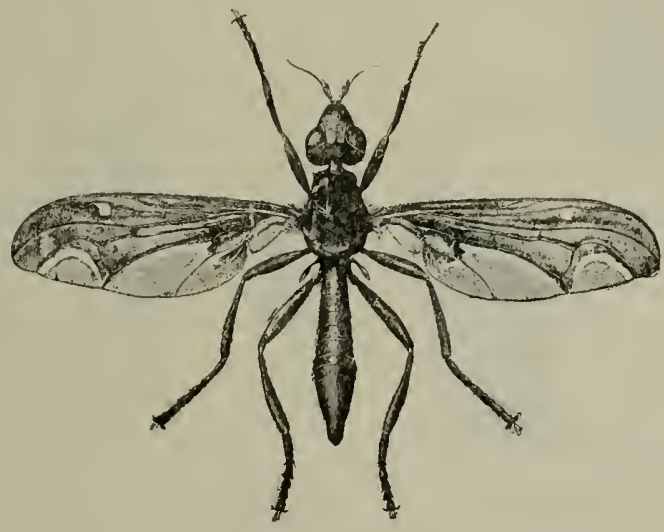

Fic. 30. Pyrgota undata Wied., female.

usually sufficiently disturbed to cause it to drop, at the same time spreading its wings to break the fall. The fly immediately takes advantage of this act to thrust its ovipositor through the exposed thin abdoninal wall beneath the wing covers and to lay an egg in the abdomen. The abdomen and ovipositor of Pyrgota are admirably adapted to this act, the former being curved, with the tip hard and conical, and the ovipositor being a fleshy nuscular organ of medium length with a sharp-pointed chitinous tip (Fig. 31). 
The eggs are elliptical, measuring $.05 \mathrm{~mm}$. by $1.2 \mathrm{~mm}$., and pure white (Fig. 32). Counts of eggs in the bodies of two specimens of $P$. undata, made May 29, 191:, gave 54 and 98 respectively. The length of the egg stage has never been determined by us, but it is probably only five or six days, since the beetles are killed by the maggots within ten days or two weeks after being attacked, and the average length of the egg and larval stages combined is about three weeks. Before succumbing to the attack of the parasitic larva the beetle enters the earth to a depth of two to six inches, and within the abdominal cavity of the host the larva pupates and remains as a puparium until the following spring. Occasionally some of the tachinid parasites issue in the summer of the same year in which they pupate, but this never occurs with Pyrgota, and we have never found more than one Pyrgota developing within the same host. Rarely the Pyrgota remains in the puparium stage over two winters. In one case a male $P$. futilis caged June 12,1916 , was found to contain a parasitic larva June $2 \%$, this larva forming the puparium

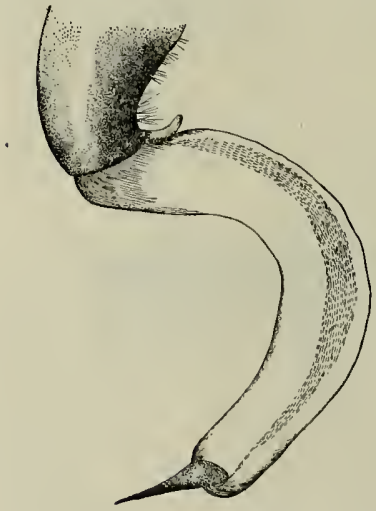

FIG. 31. Pyrgota undata Wied., ovipositor extruded.

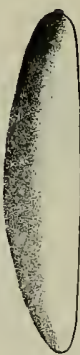

Fig. 32, Pyrgota undata Wied., egg, much enlarged.

shortly thereafter, and although other parasites of the same species and from the same lot issued in the spring of $191 \%$, one remained over the second winter and issued as an adult female P. undata May 11, 1918, about two years after it was first observed in the host. The larva (Fig. 33 ) is white and very robust, and in this respect might be likened to some of the larger nut-weevils. The puparia of the two species (Fig. 34 , and P1. X, Fig. 41) are quite distinct and readily recognized. They are alike in shape, being broadly ovate, noticeably thicker and broader at the rounded anal end, the anterior end being pointed, hut differ in size, texture, and posterior spiracles. The puparium of $P$ ttndata is the 
larger of the two, averaging about $4.8 \mathrm{~mm}$. at its widest point and 9.0 mm. in length, nearly smooth, and black with a slight silky luster. The posterior pair of spiracles are set a little above the median lateral line, one on each side of a small but prominent cavity which is encircled by a rugose ridge. $P$. valida is a smaller species, the puparium (P1. X, Fig. 41) of which measures about $4.0 \mathrm{~mm}$. at its widest point, and. .5 mm. in length. It is dull black, coarsely punctate, being covered throughout with closely placed deep punctures. The spiracles are distant from the median lateral line and there is no trace of a cavity as described for undata. The adult flies are rather grotesque in appearance, being about as large as a medium-sized wasp, the head pointed at the apex and subtriangular or conical, with prominent eyes, the thorax of the usual size. and the abdomen slender at the base but broadening apically, and narrow-

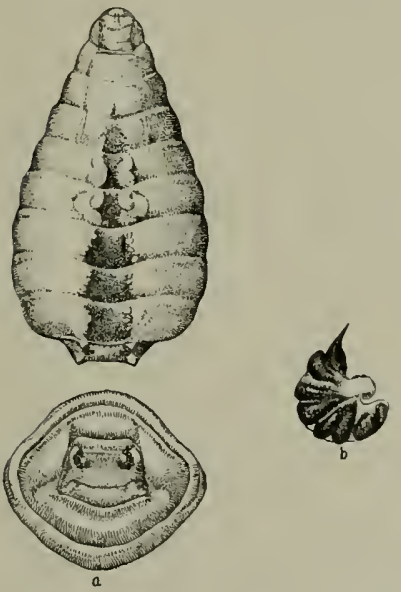

FIG. 33. Pyrgota undata Wied, larva; $a$, posterior end, showing posterior spiracles: $b$, one of the spiracles much enlarged.
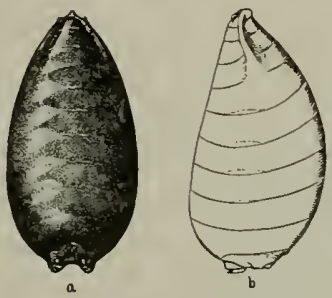

FIg. 34. Pyrgote undata Wied., puparium, (a) ventral and (b) lateral view.

ing again in the female to a conical tip. The body and legs of undata are brownish, and the wings, excepting the posterior nargins, are of the same color (Fig. 30), while in zalida the body and legs are blackish and the wings mottled with black (Pl. XI, Fig. 42).

Pyrgota undata appears to be the more common of the two species and has been recorded from such widely separated localities as Quebec. (Canada), New Jersey, and Kansas. We have reared it from nime species of Phyllophaga, namely, $P$. bipartita, ferida (=arcuata), fra- 
terna, fusca, futilis (=gibbosa), hirticula, ilicis, implicita, and rchemens, collected from Illinois, Indiana, Missouri, Wisccnsin, and Virginia, as follows: St. Louis, Mo. (Phil. Rau) ; Charlotiesville, Va., (H. Fox and W. J. Phillips) ; and from Milford and Sheldon, Ill., Lafayette, Orleans, Princeton, and Vincennes, Ind., and Lancaster, Wis. (members of the Lafayette Station staff, including R. J. Kewley, D. G. Tower, A. F. Satterthwait, H. J. Hart, F. A. Fenton, S. L. Mason, and the writer). In addition we have found puparia of this species in the bodies of $P$. hirtiventris and $P$. calceata collected in 1914 at Pauls Valley and Shawnee, Okla., respectively, by $\mathrm{Mr}$. W. E. Pennington, the parasitized beetles being among a lot which had previously been caged for eggs and later sent in for deternination. An empty undata puparium was found in the body of a dead female $P$. hirticula picked up behind the plow by Mr. C. M. Pacliard at Hagerstown, Md. Other distribution records of $P$. undata in our files include Tempe, Ariz. (V. L. Wildermuth), Ithaca, N. Y.. and Indianapolis, Ind. (H. Morrison), and New Haven, Conn., and Linglestown, Pa. (Champlain). The dates of emergence according to our 166 rearing records are May 8 to May 30, and in the field we find the species most common about May 20-24. Female beetles are much more frequently parasitized than males, and there appears to be some evidence that male flies are more frequently produced in the smaller species of beetles; in other words, the supply of food appears to have an influence in determining sex.

Pyrgota valida was bred from thirteen species of May-beetles, namely, $P$. anxia (=dubia), balia, calccata, crassissinia, crenulata, feriida (=arcuata), fusca, futilis, (=gibbosa), hirticula, implicita, inz'cra, rugosa, and tristis collected as follows: Strathroy and Wilton Grove, Ontario, Can. (collected by H. G. Crawford), Manhattan, Kan. (J. W. McColloch), Wakeman, O. (W. B. Hall), and Sheldon, Ill., Lafayette and Orleans, Ind., Battle Creek, Farmington, Holland, Imlay City, and Port Huron, Mich., and College Station, Tex. (members of Lafayette Station staff, including D. G. Tower, H. J. Hart, A. F. Satterthwait, R. J. Kewley, F. A. Fenton, S. L. Mason, and the writer). In addition a puparium of this species was found in the body of a female $P$. calceata obtained at Shawnee, Okla., in 1914 by W. E. Pennington. In literature it has been recorded from New York to Illinois, and $\mathrm{Mr}$. E. G. Kelly has collected the adult at Wellington, Kansas. The adult of valida emerged, according to our 95 cage records, much earlier than undata, that is from April 23 to June 5, and out-of-doors it is found most often early in May, although we have taken it at Lafayette, Ind., as late as May 25, while collecting beetles from trees at night. $P$. r'alida, as in the case of undata, has a one-year life cycle, only one larva develops in a beetle, and females seem to be more readily subject to attack than males, although this tendency is more marked in our undata records.

Both species frequent trees at night where the beetles are feeding, and both sexes are often attracted to electric lights, sometimes in very conspicuous numbers. 
These species are not as abundant nor apparently as wide-spread as our common tachinid (Cryptoneigcnia theutis), but in some sections where they occur in sufficient numbers they are undoubtedly beneficial to a marked degree, especially as they most frequently attack the female beetles. Although these may lay a few eggs after being parasitized, our studies up to the present time indicate this to be the exception rather than the rule.

We have never reared a parasite of Pyrgota, but Mr. E. G. Smyth has done so and has sent us two examples of the parasite, which were determined by Mr. S. A. Rohwer as a new genus and new species in Bethylidae. Mr. Smyth reared these from a Pyrgota undata puparium found in Illinois in 1914 by Mr. G. N. Wolcott, and writes that a number of the parasites issued from a single puparium.

\section{Tachixid Flies}

In our studies three species of tachinid flies (Cryptomeigenia theutis, Eutrixa exile, and Bionyia lachnosternac) have been reared from Naybeetles, and of these $C$. theutis is much the most common and wide-spread and seems to be the most beneficial of the parasites attacking the Phyllophaga adult. The three species can be readily distinguished in the adult and pupal stages by characters shown in the accompanying illustrations of the flies and the posterior spiracles of the larvae or puparia (Fig. 35, 36, and 41-43). Two other species (C. aurifacies and Eutrixoides jonesii), which occur in Porto Rico, are briefly treated.

\section{Cryptomeigenia theutis Walk.}

The first published record of the parasitic habits of this species is that of Coquillett (13), who reports it as having been reared by Theo. Pergande from an adult Phyllophaga inversa taken at Washington, D. C., May, 1892, the fly issuing Mar. 23, 1893. The species occurs generally throughout the northern states east of the Rocky Mlountains, and its distribution, according to published records and our own studies, includes Toronto and Montreal, Canada; New Hampshire. Massachusetts. New York, New Jersey, District of Columbia, Ohio, Indiana, Michigan, Wisconsin, Illinois, Kansas, Mississippi, Virginia, and Tennessee; and Mr. Norman Criddle writes Jan. 10, 1918, that he has reared it from May-beetles collected in Manitoba, Canada.

We have reared theutis only from Phyllophaga, including the species drakii (=grandis), fcrvida (=arcuata), fratcrna, fusca, futilis (=gibbasa), hirticula, ilicis, implicita, ine'cra, micans, rugosa, tristis, and vehemens, but the writer once observed it in the act of laying an egg on an adult Diplotaxis, and it is not unlikely that further study will show it to be parasitic on certain of the larger Diplotaxis and beetles of related genera which feed on tree foliage at night. The fly (Fig. 35), which is about the size of the common house-fly and superficially resembles it, is frequently seen resting on tree foliage at night. At Lafayette, Ind., we find it throughout the month of Mlay, sometimes earlier, 


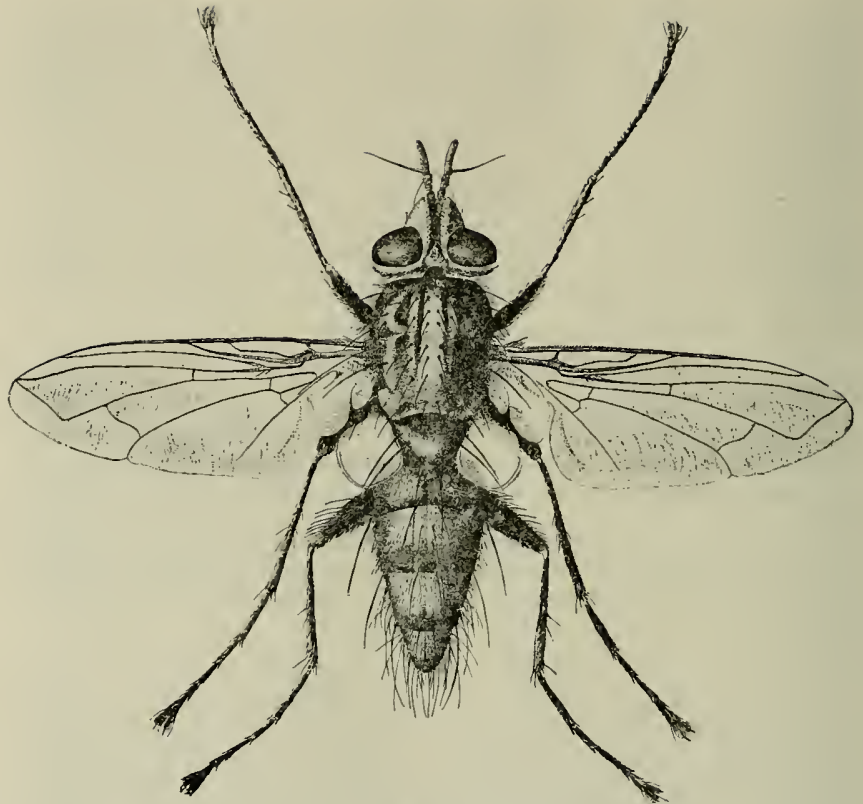

Fig. 35. Cryptomeigenia theutis Walk., male.

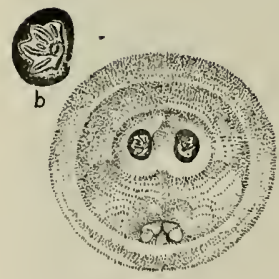

a

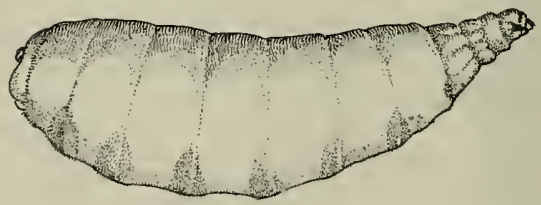

FIG. 36. Cryptomeigenia theutis Walk., larva; $a$, anal end, showing posterior spiracles; $b$, posterior spiracles much enlarged. 
and frequently during the month of June. In the act of oviposition the fly stealthily crawls onto the beetle while the latter is feeding or copulating at night and proceeds to lay one or more eggs, which it fastens to the body of the beetle by means of a glutinous secretion. The eggs (Fig. 37) are light brown, oval, measuring $.36 \mathrm{~mm}$. by $.66 \mathrm{~mm}$. They are frequently laid on the abdomen, tstually at the side and near the edge of the elytron (Pl. X, Fig. 40) or they may even be slipped beneath the iving cover. They are sometimes laid on the hard parts of the body, such as the elytra and thorax, but it is questionable whether larvae hatching from eggs thus deposited are able to enter the body of the host. The larvae (Fig. 36) enter the abdominal cavity of the beetle and devour the fatty tissues, funally attacking the vital organs and thus killing the host. Before succumbing to the attacks of the parasitic larvae, in fact several days before death, the beetle almost invariably enters the soil to a depth of several inches, sometimes 6 or 8 , the larvae pupating within the body cavity and remaining there as a rule until spring of the following year.

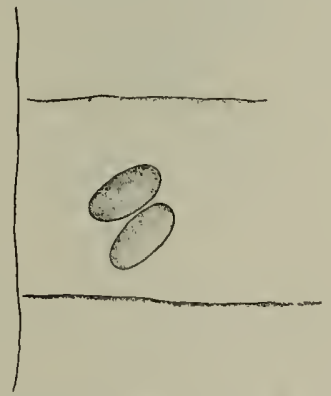

FIG. 37. Cryptomeigenia theutis Walk,, eggs, much enlarger.

This species is the most frequent beetle parasite according to our observations, which include over 850 rearing records from the following localities: Manhattan, Kan. (J. W. McColloch and W. P. Hayes), Greenwood, Miss. (J. M. Langston), Wakeman, O. (W. B. Hall), Clarksville, Temn. (H. Fox and P. Wyatt), Richmond, Va. (T. S. Herbert), Tappahannock, Va. (H. Fox), Milford and Sheldon, Ill., Akron, Huntingburg, Lafayette, Orleans, Princeton, and Vincennes, Ind., Battle Creek, East Leroy, Farmington, Imlay City, Mendon, Port Huron, and Richland, Mich., Napoleon and Swanton, O., and Trout Iake, Wis. (members of Lafayette Station staff, including R. J. Kewley, D. G. Tower, A. F. Satterthwait, S. I. Mason, F. A. Fenton, H. J. Hart, C. F. Turner, and the writer). The names in parenthesis indicate the collectors, who greatly helped the investigation by sending in specimens of 
live May-beetles. In some cases the flies issued the year they killed the beetles, but most of those forming puparia in the spring of one year did not issue until the spring of the following year. From this and other data it is certain that under natural conditions the flies normally have a one-year life-cycle. In our cage experiments flies began to issue soon after the cages were removed from their winter quarters, that is about April 20, and continued to issue until early in May. These dates are somewhat earlier than is normal out-of-doors, the first emergence of flies usually being coincident with or shortly after beetle emergence, which in the latitude of Lafayette is, as a rule, the last few days in April. It would appear that both sexes of beetles are attacked indifferently, since the number of male and female beetles from which the flies are reared is almost exactly the same. From one to seven larvae may develop in a single host, although we have never reared to the adult more than five from one beetle, and the average of the 134 examples observed in 1916 is 2.8 larvae to each beetle.

$C$. theutis seems to be parasitized by a very interesting hymenopterous parasite (Lepidopria aberrons Brues). At Hagerstown, Md., August 15, 1913, Mr. J. A. Hyslop, of the Bureau of Entomology, found a dead female Phyllophaga inversa containing two dipterous puparia, which agreed with those of $C$. theutis. Each puparium showed two minute holes, and when opened one contained the shriveled remains of a fly and the other the fragments of an apterous hymenopteron which was determined and described by $\mathrm{Mr}$. C. T. Brues as the abovementioned species (10). We have occasionally found puparia showing minute holes, but have never found the parasite which was presumed to have made them.

\section{CRYPTOMEIgenia aurifacies Walton}

This and the following species have been reported as parasites of Phyllophaga adults in Porto Rico but are not known to occur in the United States. C. aurifacies (Fig. 38, 39) was described and first recorded as a parasite in 1912 by Mr. W. R. Walton (80), and was later reported by Mr. D. L. Van Dine (78) as bred from beetles collected in several localities in Porto Rico. It is closely related to our common $C$. theutis, but may be distinguished from that species by the dorsal vittae of the thorax, which are distinctly velvety black, these markings being indistinct brownish in theutis; likewise the sides of the face of aurifacies are distinctly golden yellow pollinose, the face of theutis being gray.

\section{EUTRIXOIDES JONESII Walton}

A second tachinid parasite, not known to occur in the United States, was bred from Phyllophaga adults in Porto Rico by Mr. T. H. Jones in 1912, and the species described by Mr. Walton in 1913 (81). Although closely related to our American May-beetle parasite, Eutrixa exile, it is distinguished, according to Mr. Walton, by the remarkable development of the ovipositor (Fig. 40), and in the male by its much narrower front and face. 


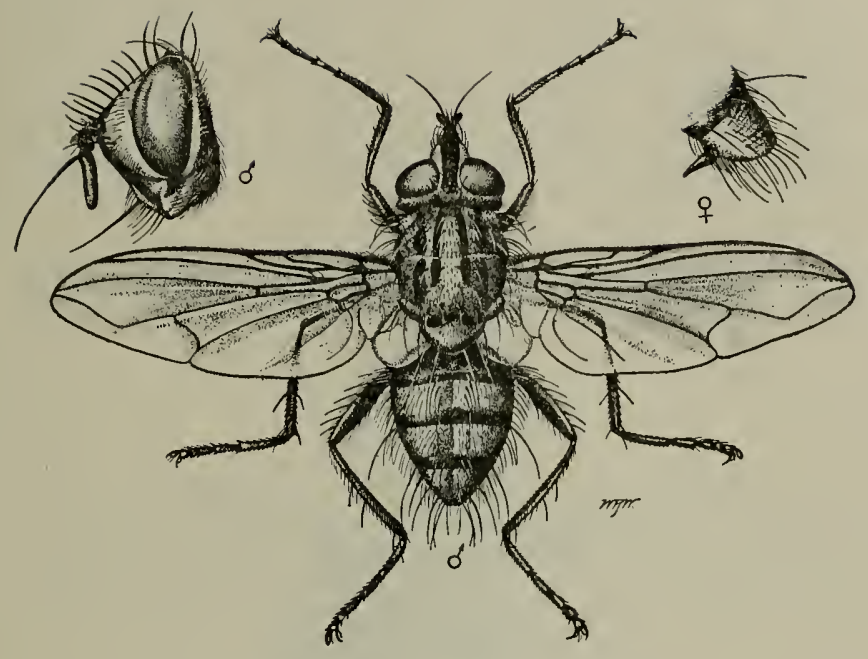

F1G. 38. Cryptomeigenit aurifucies Walt, (After Walton.)
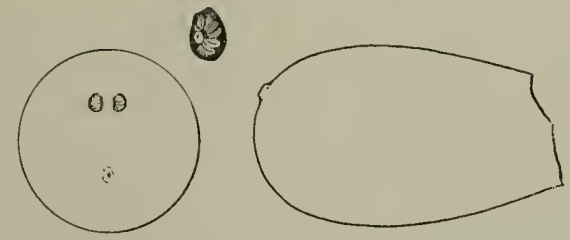

Fig. 39. Cryjtomfigentia arifacies Walt, puparium (anterior end missing), anal end, showing position of spiracles, and one of the spiracles more enlarged. 
Eutrixa exile Coq.

This species (Fig. 41) was first reported as a May-beetle parasite in 1897 by D. W. Coquillett under the name Eutrixa masuria Walk. (13). The flies issued March 12, 16, and 23, 1895, from a $P$. arcuata adult obtained at Washington, D. C. It is almost as wide-spread as Cryptameigenia theutis, the published records giving its distribution as Ontario, Canada; New Hampshire, New York, Maryland, District of Columbia, Virginia, Ohio, Indiana, Michigan, and Wisconsin. Our records show it to occur also in Mississippi, Missouri, and South Carolina. Although the species occurs more commonly in the Northern States, it seems to be less typically northern than $C$. theutis.

We have reared the species from fifteen species of Phyllophaga, namely, $P$. antia (=dubia), drakii (=grandis), fervida (=arcuata), fraterna, fusca, futilis (=gibbasa), listicula, ilicis, implicita, prafunda

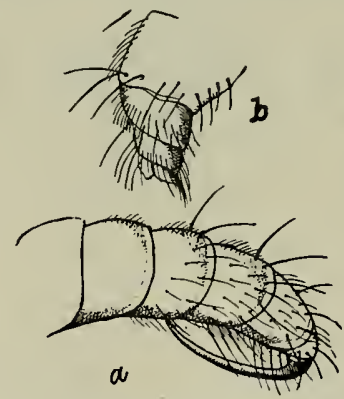

Fig. 40. Tip of abdomen (a) of E'utrixoides jonessi Walt., and (b) of Eutrixa exile Coq.

rugasa, tristis, vehcmens, vilifrans, and new species $b, *$ and from beetles representing 200 records and collected in twenty-four localities as follows: Strathroy and Wilton Grove, Ontario, Canada (beetles collected by H. G. Crawford) ; Starkville, Miss. (G. F. Arnold); Mt. Grove, Mo. (M. P. Somes) ; East Greenbush, N. Y. (E. P. Felt) ; Winfield Junction, L. I., N. Y. (Jay Sedgwick) ; Wakeman, O. (W. B. Hall) ; Charlottesville, Va. (W. J. Phillips and H. Fox) ; Richmond, Va. (T. S. Herbert); Sharps and Tappahannock, Va. (H. Fox); and from Akron, Lafayette, Orleans, Princeton, and Vincennes, Ind.; Adrian, Battle Creek, East Leroy, Farmington, Imlay City, and Port Huron, Mich.; Swanton, Ohio; and Platteville and Trout Lake, Wis. (members of the Lafayette Station staff). In addition, Mr. Philip Luginbill, of the Bureau of Entomology, reared it in 1913 from an adult $P$. tristis taken

* An undescribed species in author's collection. 
at Columbia, S. C., and Mr. Rees Philpott reared two of the flies May 3, 1915, from a single Phyllophaga beetle found two days before in the soil at Delaware, Ohio.

We have not studied all the details of the general habits and life history of this species, but as far as known they agree with those of $C$. theutis, the fly being nocturnal and laying its eggs on the beetles while they are feeding or resting on tree foliage at night. Some of the flies issue the same season they parasitize the beetle, that is during July, about one month after puparia are observed, but this is probably due to the conditions referred to in the discussion of $C$. theutis, and in a natural

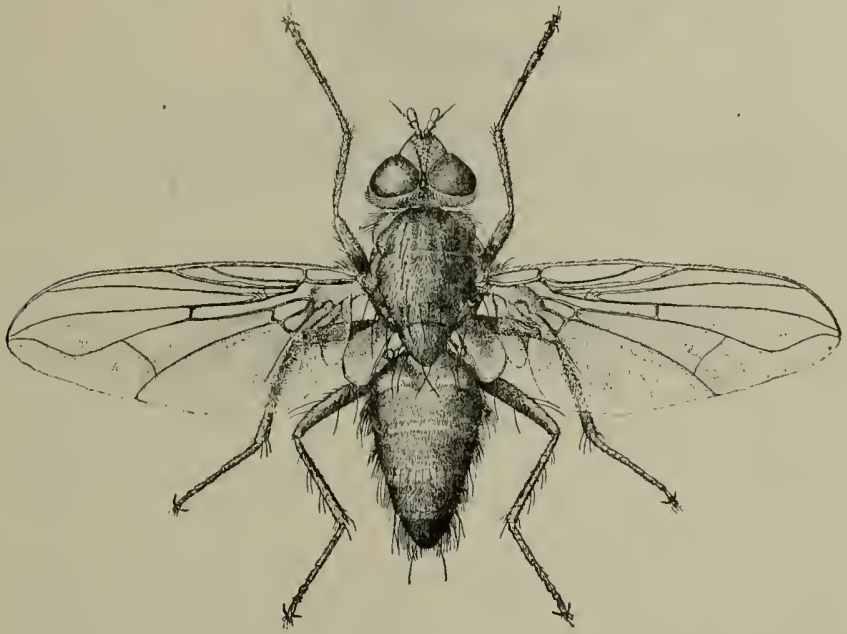

Fig. 41. Eutrixa exile Coq., male.

enviromment the life cycle is probably normally one year. In cages the flies begin to appear soon after they have been removed from the conpost heap where they are kept during the winter months, but under normal out-of-door conditions emergence is coincident with the appearance of May-beetles or a little later, their first appearance usually being a few days or a week after that of $C$. theutis. Our records show that the male and female beetles are about equally attacked and that from one to eight larvae develop in a single host, the average for 183 examples being two to a beetle. 
E. crite may be distinguished in the larval and pupal stages from other parasites of May-beetles by the characteristic posterior spiracles, illustrated in Figure 42

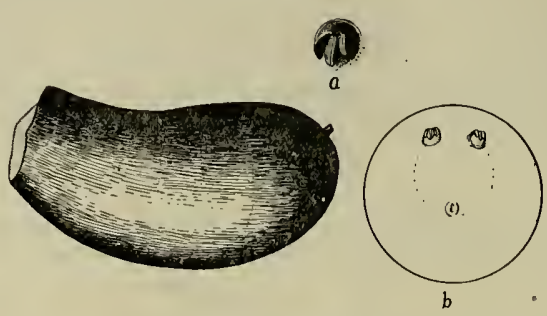

FIG. 42. Eutrixa exile Coq., puparium from which adult has issued: $a$, posterior spiracles, much enlarged; $b$, anal end, showing posterior position or posterior spiracles.

Bromyta lachinosternae Towns.

Biomyia lachnostirnae was first reared by the writer in 1905 from an adult Phyllophaga crenulata taken at Urbana, Ill., and was recorded by Dr. S. A. Forbes (26) as a species of Viviana. This was later described by Mr. C. H. T. Townsend as a new species under the name $V$. lachnosternae ( 75$)$. The beetle referred to above was obtained July 15 , laid three eggs after being placed in a flower-pot cage, and died about July 29, the fly (Fig. 43) issuing August 5, after the beetle had been pinned. We have also reared it from beetles collected in Mississippi, South Carolina, and Virginia, and it is apparently typically a member of the southern fauna.

In our rearing experiments we have bred this parasite from 89 beetles representing nine species of Phyllophaga, namely, $P$. calceata, ephilda (=burmeisteri), forbesi, forsteri (二nova), luctuosa, prununculina, quercus, v'chemens, and new species $b$. The beetles from which they were reared were collected at Agricultural College, Miss. (collected by students through the courtesy of Professor R. W. Harned). Greenwood, Miss. (collected by J. M. Langston); Gulfport, Miss. (C. C. Greer); Columbia, S. C. (Philip Luginbill); and Charlottesville and Tappahannock, Va. (H. Fox). It differs from the two preceding in that not more than one maggot normally develops in a single beetle, only one case having been observed in which as many as two flies came from the same host, and according to all our records the adults invariably issue within 45 days of the time when they were collected and caged. We have not studied the species under conditions occurring in the Southern States, its normal habitat, but the evidence at hand 
indicates a second seasonal generation, and this is possible since adult Phyllophaga of one species or another are active in the Southern States from the latter part of March until the middle of August.

The species may prove to be an appreciable aid in the control of Phyllophaga in the Southern States.

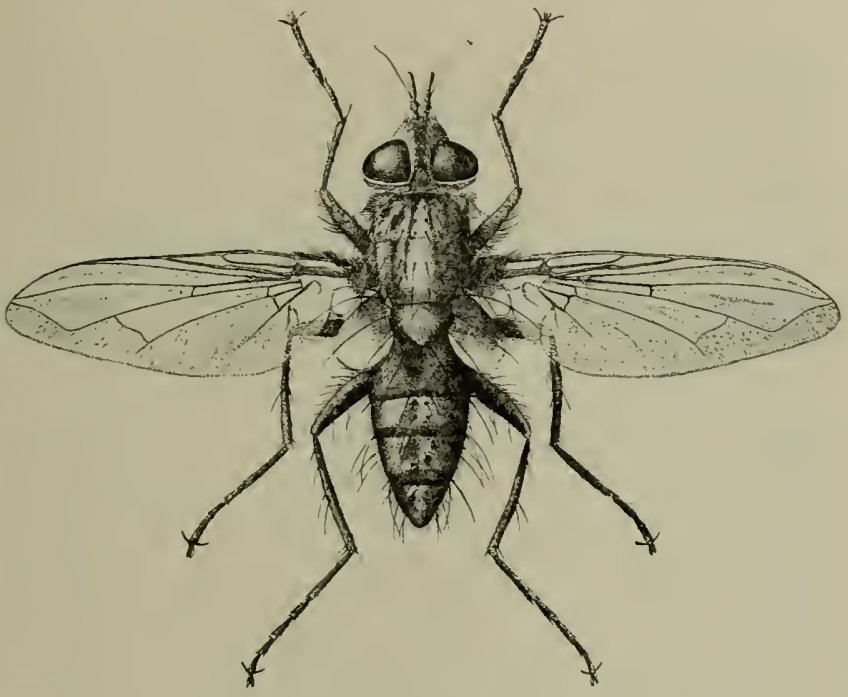

FIg. 43. Biomyia lachnosternat Towns., nule.

Sarcophagids, includixg Docbtfit Records

Several sarcophagids have been recorded in literature as parasitic on Phyllophaga adults, and we have occasionally reared them-and once an anthomyiid-in cages containing May-beetles, but in most cases it was plainly evident that the flies had hatched from maggots which fed only on the dead beetles. In all cases where these flies have been reared at the Lafayette Laboratory, the cages were covered with wire-screen, pernitting larvae or eggs to be thrust into the cage through the meshes. Furthermore, all such rearing records were from cages containing large numbers of beetles confined for parasites, and the dead beetles and abundant excrement were no doubt attractive to the scavenger flies. It might be noted that the sarcophagid larvae invariably left the dead 
beetles to pupate, which is never the case with the beetle parasites already treated. Of the eight sarcophagids bricfly treated in this connection only the first four ( $S$. prohibita $S$. tubcrosa, var. sarraccnioides, $S$. cimbicis, and $S$. new species) are probably true parasites of May-beetles. Like other sarcophagids they are active during the daytime, and each of the four was reared froni a diurnal May-beetle.

\section{Sarcophaga prohibita Ald.}

We have only one rearing record of this species. In a lot of Pliyllophaga lanccolata received at Lafayette, Ind., July 4,1916 , from J. IV. McColloch and W. P. Hayes, and collected at Manhattan, Kan., three days previous, one male and one female beetle were dead July 6 , each containing a dipterous larva. One fly issued July 25, 1916, but was destroyed in the mail before being determined. The other fly issued June 5, 191\%, and was determined by Dr. Aldrich as his prohibita. From the facts that both beetle and fly are diurnal, that the beetles were alive when received at Lafayette, and that prohibita is not known to occur in. Indiana but is more or less common in Kansas, it seems reasonably certain that this fly is a parasite of Phyllophaga.

Sarcophaga tuberosa Pand, var. Sarracenioides Ald.

We have never observed this species, but Dr. J. M. Aldrich (‡) records it on the authority of Mr. E. G. Kelly as having been reared from adult Phyllophaga. Mr. E. L. Barrett, of the U. S. Entomological Laboratory at Wellington, Kan., obtained a number of this species July 13, 1916, from a screen-covered cage containing adult Phyllophaga lanceolata collected June 9, 1916. The cage had been sifted July 10, at which time the puparia of this fly were found in the dirt. It is probable that this sarcophagid is a true parasite of the diurnal lanceolata, but it is evident from our present knowledge of the Sarcophagidae that it is possible for the flies to deposit their larvae through the wire screen, and this is especially likely when the cages contain large numbers of beetles, many of which die on the surface, the dead bodies together with the abundant excreta being attractive to female sarcophagids. This fly has been recorded as parasitic on several insects and has also been reared from human excrement, dead fish, etc. Its range is from Virginia to Washington and British Columbia on the west, and south to Texas and Arizona.

\section{Sarcophaga cImbicis Towns.}

This species was obtained from a screen cage containing Phyllophaga lanccolata by Mr. E. L. Barrett at Wellington, Kan., and was reared along with $S$. tuberosa var. sarracenioides, notes for which have just been given under that species heading. It is probably a true parasite of this diurnal May-beetle, but further exact experiments will be necessary to prove this beyond doubt. The species was originally reared from the willow sawfly (Cimbex americana), and no further records of its parasitic habits have been published to my knowledge, although it ap- 
pears to be a rather common species with a range alnost as extensive as that of sarracenioides.

Sarcophaga, n. sp. (Aldrich det.)

May 6,1918 , we received two pinned male Phyllophaga farcta from F. B. Paddock, which bore the label "Lometa, Texas, April 30, 1918". On receipt the abdomen of one beetle was found loose in the box, together with two sarcophagid larvae, one of which was inmature and did not issue, the other issuing as an adult fly May 20. It was determined by Dr. Aldrich as a new species belonging, according to genital characters, to the group known to be parasites.

SARCOPHAGA HELICIS Towns.

$S$. helicis has been repeatedly reared from larvae and puparia from cages containing numbers of May-beetles caged for parasites, and the dying beetles were no doubt responsible for the attraction of helicis adults and their subsequent oriposition in the cage through the wire screen. Repeated unsuccessful attempts have been made to induce the flies to infest live beetles, and it might be mentioned in this connection that Mr. A. F. Satterthwait conducted at Lafayette, Ind., a number of experiments to ascertain whether the flies of this species would infest live army-worms (Cirphis unipuncta), all these experiments resulting negatively.

In $1893 \mathrm{Mr}$. C. H. T. Townsend ( $i t)$ listed this species among a lot reared from Phyllophaga by Dr. Forbes, but there is no evidence that they were reared from live beetles. Dr. J. M. Aldrich (?) also records it as having been reared from Phyllophaga adults at Washington. D. C., in 1893. but he questioned this record and considered it as probably a scavenger. The writer believes there is no basis for regarding $S$. helicis as a parasite of Phyllopliaga, but there is sufficient evidence to prove its scavenger habits.

\section{SARCOPHAGA UTILIS Ald.}

We have reared $S$. utilis from a dead Pelidnota punctato adult, from loose puparia in the soil of Phyllophaga cages, and in one instance from a larra found in the body of a dead female $P$. implicita. , The beetles in the cage in the last-mentioned case were collected at Lafayette, Ind. June 21,1915 , and the dead implicita beetle containing the nearly fullgrown larva of $S$. utilis was found July 2. The larva left the beetle and pupated in the soil several days after, and the adult fly issued August 12. We have also reared it from dead Cotinus mitida adults, in which case it was almost certainly a scavenger, and Mr. MT. R. Walton reared it from a dead Geotrupes splcndidus (2).

The possibility of this species being parasitic on Phyllophaga is very mnch to be doubted in the face of the evidence at hand.

\section{Sarcophaga Falculata Pand.}

This fly was obtained by E. G. Kelly and J. S. Wade from a cage containing May-beetles collected at Charleston. Mlo., by Vernon King, 
but there is no evidence that they were reared from live beetles, and it is hardly possible that they were. This species has been reared, according to Aldrich (2), from decaying meat.

Fannia canicularis Linn.

This interesting little fly, frequently found in houses and therefore termed the little house-fly, was reared from a female Phyllophaga velemens obtained by J. M. Langston at Greenwood, Miss. The live beetles were collected April 24, 1915, and received at the Lafayette Laboratory April 28. The cage was examined May 4, at which time the dead beetles were discarded, and when again examined, May 28, one beetle was found to contain a dipterous puparium, the adult fly, determined by Dr. Aldrich as F. canicularis, issuing July 20 of the same year. This species is only known to breed in decaying vegetable matter, dead insects, or animal excreta, and there is reasonable doubt as to whether it is sometimes a true parasite, or purely a scavenger as we have assumed.

\section{Spiders as Enemies of May-beetles}

Although not generally active enemies, several species of spiders have been seen attacking live May-beetles at night. Most frequently the grubs are caught in the webs and are there taken by the spider, but the writer has seen one case of a truly predaceous attack. While col-' lecting beetles from trees at Lafayette, Ind., May 20, 1912, an adult Plyyllophaga implicita was seen to alight on a peach tree about dusk $(\tau: 15$ p. m.), and several minutes later, after it had begun to feed, it was seized by a spider, determined by Dr. Nathan Banks as Lycosa helluo Wakeman.

Another spider, Xysticus gulosus Keys (Banks det.), with a captured $P$. futilis, was taken at Lafayette, Ind., May 12, 1915, by Mr. A. F. Satterthwait, of the Bureau of Entomology.

At Princeton, Ind., June 29, 1916, while collecting May-beetles from trees, a number of spiders, all of the same species and determined by Nathan Banks as Plectana stellata Hentz (Pl. XI, Fig. 46, 47), were observed attacking May-beetles ( $P$. implicita) which had been caught in the webs, and the same spider was seen attacking May-beetles in a similar manner at Lafayette, Ind. Mr. G. G. Ainslie found an adult of $P$. fusca in the web of this spider at Knoxville, Tenn., and the writer saw an adult $P$. congrua attacked and killed by the same species at New Orleans, La.

\section{Diseases of the larva}

\section{A Nematode Disease}

A new white-grub disease, caused by nematodes, appeared in beneficial abundance in the vicinity of Lancaster, Wis., during the late summer and fall of 1915 , but although many other localities where grubs were abundant were visited and a special search was made, the new 
disease was not found elsewhere. August 19, 1915, the writer was informed by Mr. Frank S. Turner, a farmer living a mile east of Lancaster, that the grubs seemed to be dying in one of his fields where they had destroyed most of the corn that summer. An examination showed that a third or n1ore of them were dead and yellow or decayed, and by October 5 at least 90 per cent. of the grubs had died. The disease was also prevalent in neighboring fields to a distance of three-fourths of a mile to a mile. With one exception, every field in which the dying grubs were found had been in timothy the year before, that is, the year the beetles were abundant, but whether this had any significance other than that such land is usually the worst infested with grubs, can not be told at this time. The one exception was a corn field which was in oats the previous year and adjoined a field which contained diseased grubs. According to Mr. Turner's observations the disease made its appearance in a very wet spell about the first of July, and five or six weeks later, when the writer visited the field, a third of the grubs had been killed. Towards the end of August and following a period of wet weather newly affected grubs again became numerous, but shortly after this a dry spell seemed to retard the spread of the disease. From these
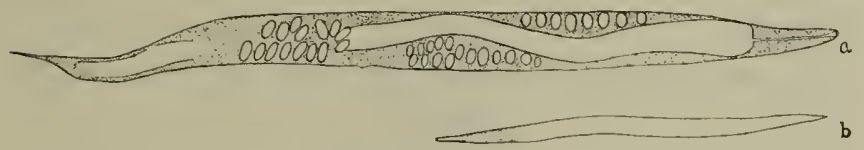

F19. 44. Nematodes found infesting white-grubs: $a$, mature indivdiual:

b, immature worm.

observations it seems likely that moisture plays an inportant rôle in the occurrence, abundance, and spread of this nematode infestation. Affected grubs were usually within six inches of the surface. They have a characteristic appearance (P1. XII, Fig. 49), recently killed grubs being of a peculiar lemon-yellow color and the body fluids yellowish green. A few days or a week later they begin to take on a brownish color, due apparently to decay, and several weeks after the death of the grub decay and disintegration is complete. The bodies of the dead grubs are filled with thousands of small nematodes, and frequently, with the aid of a magnifier, the active parasites are plainly visible through the skin of the host. The appearance of the nematode as it occurs in the grub, is shown in Figure 44. Individuals which appeared mature measured $2.17 \mathrm{~mm}$., the smaller ones measuring .39 to $1.00 \mathrm{~mm}$., and the average being approximately $.80 \mathrm{~mm}$.

Grubs were sent to Dr. N. A. Cobb, who found two species present, one being Diplogaster acrivora Cobb, and the other immature Cephalobus (?) sp., the primary affection being considered by Dr. Cobb as due to the Diplogaster, although this point was not positively determined. An account of the life history and habits of $D$. aerivora has heen pub- 
lished by J. H. Merrill and A. L. Ford ( 21 ), who found it attacking Lcucotermes lucifugus and grasshoppers' eggs in Kansas. The nematodes were found parasitic 11 the heads, and in no case were they found in the abdomen of L. lucifugus, although after the death of the host they might feed within or on any part of the body.

\section{A Protozonan Disease}

While investigating reported white-grub injury on the farm of Robert Evans, seven miles northwest of Hoopeston, Ill., September 25, 1912, Mr. W. P. Flint and the writer observed live and dead grubs lying on the surface, and upon close examination also found sickly or dead grubs just below the surface, their presence being indicated by a slight cracking of the surface crust (16). Specimens were sent to Dr. R. D. Glasgow, who was at that time employed by Dr. S. A. Forbes to investigate white-grub diseases, and he pronounced the affection due to a protozoan parasite. The field containing the diseased grubs was a 60-acre corn field, 15 acres of which had been ruined by grubs of the 1911 brood of May-beetles. The soil in the field was a rich black loam and the field had been in oats the preceding year. A month later (October 2y) the field was again visited and dead grubs were found quite abundant in the soil in the worst-infested parts of the field. Most of those on the surface were dry and readily blown about by the wind. Many other diseased grubs, and some dead, were found in the soil at a depth of $1 / 8$ to $11 / 2$ inches, their presence usually indicated by the cracking of the soil, as noted above. Grubs which were apparently free from the disease occurred 1 to $11 / 2$ feet below the surface, and although it was impossible to make an exact estimate it was evident that more than 50 per cent. of the grub population had been destroyed by the disease. It is interesting to note that although skunks had been active in searching for the grubs in this field, they had apparently not eaten any of the diseased grubs, neither those lying on the ground nor those just beneath the surface. The following season (September 30, 1913) the writer again visited the field and followed the plow in the infested area for a distance of 360 rods; but only $;$ adult beetles and 11 grubs were found, and most of these were along the edge of the infested area where the disease was least prevalent in 1912. Patches in the field were dug to a deptl of $1 / 2$ and 2 feet with similar results. The evidence showed rather plainly that the disease had destroyed most of the grubs.

A second outbreak of this protozoan disease was found October 6,1915 , on the farm of Mr. Ira E. Bryan, one mile north of Belvidere, Ill. Dead and sickly grubs were on and just beneath the surface as in the case at Hoopeston, above mentioned, and Mr. Bryan had noticed diseased grubs several weeks before our visit. An approximate estimate showed that at least 50 , or possibly 75 , per cent. of the grubs in this field were affected. It had been in sod the previous year and the grubs were from the 1914 brood of beetles. Neighboring fields heavily infested with grubs showed the same disease to be prevalent. 
These are the only localities where the disease has been found, and in both cases it has proved a very effective check. Our facilities have not provided for a study of Protozoa, and nothing is known of the propagation of this species, either artificially or under natural conditions. whether it is a direct or indirect parasite, or whether it can be utilized artificially for the control of white-grubs.

The affected grubs are characterized by their habit of coming to the surface of the ground, or near to it, and at a season when, according to our observations, the natural migration would be dowmward, but they present no unusual appearance except that they look sickly and entaciated and gradually dry up-as one might expect any grub to do if exposed to the sun and wind on the surface of the ground where it could not re-enter. (Pl. XII, Fig. 48.)

\section{Bacterial Diseases}

To our knowledge. but one bacterial disease affecting white-grubs has been recorded as occurring in this country, although at least two are known to attack related species in Europe. Our American disease, due to Micrococcus nigrofaciens Northrup, has been studied and described by Miss Zae Northrup (52). She concludes that the organism causing
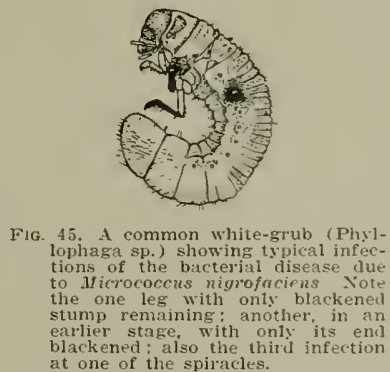

the disease is present in soils in widely separated localities in the United States and probably through most of the states. The diseased grubs are characterized by a blackening of the affected parts (Fig. 45 ). and an excessive wetness of the soil favors the progress of the disease. It has been encountered wherever we have collected grubs, and XIiss Northrup is undoubtedly right in concluding that it is generally distributed throughout the United States. According to our observations, grubs become infected only through wounds, and the infection is usually limited unless certain favorable conditions are present. Grubs are, in fact, often reared to maturity which have shown the infection in one or more of their legs. We can only conchude from this and other observations, together with 
our knowledge of the constant occurrence of the Micrococcus in soils everywhere, that it is of minor importance in the control of Phyllophaga, except possibly under exceptionably favorable conditions, and that it can not be used for this purpose artificially. This disease has been studied in Porto Rico by Mr. R. H. Van Zwaluwenburg, and his conclusions ( $\because 9)$, which agree with our own, are as follows: "The organism is present in our soils but its efficiency can not be increased by any practical means, for infection takes place usually only through a bruise or cut in the integument of the larva."

\section{Fungous Diseases}

Of the several species of fungus parasites of white-grubs, the socalled green muscardine fungus (Metarrhizium anisopliae Metsch. and its variety americana Pettit)* is the conmonest and most wide-spread (P1. XIII, Fig. 51-5\%). M. anisopliae was discovered by Metschnikoff, in $18 \% \mathrm{~s}$, attacking larvae of Anisoplia austriaca, a white grub of considerable importance in Europe. It has since been frequently referred to in literature and is now known to attack nearly all torms of insect life, being apparently cosmopolitan in its distribution. The first indication of the disease is a rigidity of the body, and this is followed shortly by the appearance of white mycelial threads, first at the joints, and later completely covering the body with a white velvety coat. Within a day or two the characteristic green spores develop-dark in the case of anisopliae and light green in the variety americana. This fungus has probably never been artificially employed with effective results on whitegrubs although it has recently proven somewhat effective in Trinidad $(6+, \pi 6)$ in the control of the sugar-cane froghopper (Tomaspis raria Fabr.). In 1913 the writer applied this fungus in several fields badly infested with white-grubs in Wisconsin and Indiana, using corn-meal cultures, some of which were grown at the Lafayette Station, but most of them furnished by Dr. S. A. Forbes. No results whatever were obtained in any case, although the grubs were abundant and the weather conditions were favorable to fungus growth. The green muscardine has also been used for the control of white-grubs in Porto Rico, and the results obtained there, which agree with our own, may be summarized from the report of the pathologist, John A. Stevenson (68). "At the south coast laboratory at Ensenada the fungus is present to such an extent as to seriously interfere at times with the progress of studies on the life history of the various beetles attacking cane. On the other hand no such success has attended the field trials which have been conducted in the neighborhood of Yauca. *** The fact that it [the green muscardine fungus] does exist here and has not become epidemic would seem to militate against the success of present experiments, especially in the light of results obtained to date." While following the plow we have found isolated cases of Metarrhizium infection in grubs of the

* Variations in color and size of spores are thought by John R. Johnston (40) to depend upon the host or the media, not being of varietal rank, but merely indications of different physiological races. 
genus Phyllophaga in various parts of Wisconsin, Illinois, Indiana, and Michigan, but have found it nowhere common. Scarabaeid grubs, and more especially grubs of the genus Ligyrus, are quite susceptible to this fungus in our breeding cages, and indeed it has occasionally interfered with our life-history studies, but the unusually favorable conditions in the cages can not be duplicated in the field, and, judging from our experience, the green muscardine can not be employed artificially as a means of controlling white-grubs in the northers half of the United States.

The white muscardine, Isaria densa Link (=Botrytis tenclla), has been experimented with against the white-grubs in Europe, and a few investigators have claimed success, but the opinions of European investigators are conflicting on the subject and the actual value of its artificial use as a measure against white-grubs is yet to be demonstrated. On the other hand there is little doubt that its wide-spread natural occurrence among grubs in the field would prove an effective check upon their injuries, as is clearly indicated by the following record. In December, 1911, Mr. W. P. Flint, of the office of the State Entomologist of Illinois, found Dhyllophaga grubs killed by $I$. densa very common, and in some places abundant, on the surface of the soil in many parts of southern Illinois, including the counties of Randolph, Marion, Jackson, Perry, Bond, Madison, and Fayette. The grubs collected by Mr. Flint and kindly sent to us by Dr. S. A. Forbes, were thoroughly mummified, as shown in the accompanying photograph (P1. XIV, Fig. 59). The fieids where these diseased grubs were found were in corn, wheat, oats, and cow-peas. Although most of the sick grubs came to the surface of the ground before dying, it was noticed by Mr. Flint that the birds apparently did not pick them up.

A fungus similar to $I$. densa (Isaria farinosa Dicks; P1. XIII, Fig. 50)has likewise been tried by European investigators with nuth the same results as those reported for 1 . densa. I. farinosa is supposed to be the "Isaria stage" of a species of Cordyceps, possibly C. militaris Linn.

Pettit (56) also records Cordyceps melolonthae ? (Tul.) Sacc., and Isaria re.rans Pettit as attacking Phyllophaga grubs.

The peculiar and characteristic Cordyceps growths on white-grubs have been occasionally mentioned in literature and most of them referred to the species $C$. melolonthae, $C$. militaris, and $C$. ravenelii. The first reference to Cordyceps on grubs in this country seems to have been made by Jacob Cist in 1824 (12). In our studies we have obtained but one true Cordyceps attacking Phyllophaga grubs, and this specimen, found in the forest tract at Trout Lake, Vilas Co., Wis., has been kindly identified for us by Dr. E. B. Mains as probably $C$. ravenclii Berk. and Curt., but it could not be determined with certainty without the fertile tip, which was broken off. We have also obtained from Mr. D. E. Walker, through the kindness of Mr. Harry F. Dietz, grubs attacked by Cordyceps herculea (Schw.) Sacc. (=melolonthac) (Mains det.). These 
diseased grubs, which are undoubtedly Xyloryctes satyrus, were collected in a forest area at Little York, Ind., July 2, 1915.

The Isaria fungi are in most cases supposed to be one stage of the Cordyceps fungi, but our knowledge of the subject is meager and views are conflicting.

Our own studies with Isaria farinosa and $I$. densa indicate rather conclusively their ineffectiveness against the white-grub in the field under normal conditions. Indeed they are even less prolific and virulent than is the green muscardine fungus, and the conditions found necessary for their active growth are seldom if ever duplicated in cultivated fields, the perfect Cordyceps stage having been found by us only in forests or partly cut-over forest-land where the proper moisture and light conditions are to be found.

\section{Pitcher-Plants and Phyllophaga}

Although probably of little economic importance, mention may be made of an interesting observation made in southwestern Georgia in a swamp near Coolidge by Dr. W. Dwight Pierce (5\%) on the insectcatching habits of pitcher-plants. In practically every, pitcher of Sarracenia catesbaei Ell., a common species in southwestern Georgia, Phyllophaga remains were found.

\section{Miscellaneous predaceous enemies}

\section{BiRDS}

Birds are among the most efficient, if not the most active, natural agencies in the control of white-grubs throughout the United States, more especially in the newer regions where they are still to be found in large numbers. Of the 52 different kinds of birds presently to be mentioned as benefiting the farmer by destroying May-beetles and their progeny, probably the crow (Corvus brachyrhynchos) and the crow blackbird (Quiscalus quiscula) are the most valuable. They are the constant companions of the plowman and diligently pick up the grubs and beetles as they are exposed. According to the records of the Biological Survey (4) both May-beetles and grubs have been found in the stomachs of crows every month of the year except January. An instance of the capacity of blackbirds for grubs was given the writer by $\mathrm{Mr}$. Henry Holzinger, of Lancaster, Wis. While a timothy sod was being plowed in 1912 a single blackbird was seen by him to eat as many grubs as possible and then, with its mouth full of them, to fly away. By actual count this bird destroyed twenty grubs in from one to two minutes. This habit of the blackbird of eating a large quantity of grubs and then flying away with the bill full, is a common one according to our observations.

In addition to the crow and the crow blackbird the Bureau of Biological Survey has listed the following birds as feeding on Maybeetles or white-grubs. They are here given in the order of their probable 
value as enemies of Phyllophaga: robin (Planesticus migratorius), * Franklin's gull (Larus franklini)*, red-winged blackbird (Agclaius phocniceus)*, killdeer (O.ryechus a'ocifcrus)*, horned lark (Otocoris alpestris)*, ruffed grouse (Bonosa umbcllus)*, upland plover (Burtramia longicauda)*, meadow-lark (Sturnclla magna* and probably $S$. ncglecta), brown thrasher (Toxostoma rufum), phoebe (Sayomis phoebc), cuckoo (Coccyaus erythrophthalmus), screech owl (Otus asio), barred owl (Strix varia)*, great horned owl (Bubo virginianus), Eastern bluebird (Sialia sialis), house wren (Troglodytes acdon)*, prairie chicken (Tympanuchus americanus), quail, or bob-white (Colinus rirginianus), sparrow hawk (Falco sparzerius)*, broad-winged hawk (Buteo platyptcrus)*, red-shouldered hawk (Butco lineatus), red-tailed hawk (Butco borealis), scissor-tailed tly-catcher (Muscizora forficata), crested flycatcher (Myiarchus crinitus), and the English sparrow (Passer domesticus)*. $(4,5,6,7,8,9,19,20,21,35,41,42,50,61$, 66.)

Mr. Norman Criddle (14) mentions the robin, flicker, grackle or crow blackbird, cowbird, and gull as enemies of grubs, but the crow is said to rank highest according to observations made in Manitoba, Canada. The cowbird (Molothrus ater), although having a bad reputation, is said to be an excellent destroyer of white-grubs, usually eating the smaller ones, but when these are not available killing the larger ones by biting their heads and eating only parts of the grubs. Mr. A. C. Burrill mentions (11) the herring gull (Larus argontatus) as feeding on Maybeetles, but its actual usefulness in this connection is not known.

The European starling (Sturnus zulgaris), which was introduced into this country within comparatively recent years, was reported to us in 1915 as an active destroyer of Cyclocephala grubs occurring in lawns at Staten Island, N. Y., and according to Mr. E. H. Forbush (27) it likewise feeds on May-beetles and white-grubs. Whether its appearance in this country will eventually prove a menace to fruit crops or to the more beneficial native birds, can not as yet be foreseen.

In his study of the food habits of the English sparrow (Passer domesticus), Dr. C. V. Riley (61) found that $\tau$ out of 92 stomachs examined contained grubs or May-beetles, while 40 contained the remains of either Tiphia or Myzine sex-cincta (=Elis 5-cincta), both of which are now known to be very important white-grub parasites. This particular study certainly shows this sparrow as noxious in its relation to the white-grub, but it has been seen to follow the plow more or less and to destroy grubs. At Elk Point, S. Dak., Mr. C. N. Ainslie, of the Bureau of Entomology, saw both English and field sparrows feeding on grubs exposed by a corn lister. At Lancaster, Wis., an observing farmer, Mr. Holzinger, told us of the inestimable value of birds in destroying grubs, mentioning especially the blackbirds and English sparrows. When plowing a sod field in 1912 he saw a sparrow following the plow. It pecked at five grubs without eating one and then ate the sixth, and upon

* Those starred eat both beetles and grubs; others, only beetles 
examination it was found that it had killed the first five, the head having been completely pulled off in one case. While following a plow in a badly infested field May 11, 1916, at Rockton, I1l., the writer saw many grubs with crushed heads, and three or four sparrows were noticed to be actively engaged pecking at the grubs as soon as they were turned out by the plow, seldom eating one but seeming to delight in pecking into their heads. At Lafayette, Ind., May 14, 1891, Prof. F. M. Webster saw an English sparrow feeding on Phyllophaga beetles which had fallen to the ground beneath an electric light the night before, and this observation has been made by others also.

A gull, supposedly Franklin's gull (Larus franklini), has been reported from various places in Nebraska, Iowa, and South Dakota as very fond of grubs. Mr. C. N. Ainslie saw flocks of gulls following the plow in infested fields at Elk Point, S. Dak., in May, 1913. They appeared to feed exclusively when on the wing, swooping close to the ground and capturing the grub without alighting. In 1912 white-grubs were very destructive near Tabor, S. Dak., and the owner of a badly infested farm told the writer of the great value of the gulls and blackbirds in destroying the grubs behind a plow or cultivator. His observations on the habits of the gulls agreed with those of Mr. Ainslie, and the blackbirds in flying to the furrows and back to a near-by grove formed a black unbroken ellipse.

In a letter to the Bureau of Entomology dated June 18, 1910, Mr. C. H. Loomis, of Platteville. Wis., refers to pigeons, as well as to crows and blackbirds, as actively feeding on grubs turned up by the plow.

Other birds which have been reported to feed on white-grubs or May-beetles are the red-bellied woodpecker (Ccnturus carolinus) and the red-headed woodpecker (Melanerpes erythrocephalus), according to the observations of Townend Glover (32); the blue jay (Cyanocitta cristata), "golden woodpecker" (Colaptes auratus?), according to Hargitt (38); chuck-wills widow (Antrostomus carolinensis), according to Dr. C. V. Riley (62); the catbird (Dumatella carolinensis), wood thrush (Hylocichla mustelina), and hermit thrush ( $H$. guttata), according to Dr. S. A. Forbes (23, 25) ; and several grackles (Quiscalus macrourus, $Q$. quiscula aeneus, $Q$. quiscula aglaeus, $Q$. major, the common ani ( $C_{r}$ tophaga $a n i$ ), and the grooved-bill ani ( $\widetilde{C}$ sulcirostris), the laughing gull (Larus atricilla,) the Virginia rail (Rallus virginianus,) meadow-lark (Sturnella magna argutula), sora (Porzana carolina), and the rice bird (Dolichony.x orvzivorus), according to observations made in Louisiana by Prof. G. E. Beyer (7\%). Crotophaga ani and Holoquiscalus brachypterus) feed on white-grubs in Porto Rico, according to Van Dine ( $i \mathrm{i})$.

While many of the above-mentioned birds are active grub-destroyers in the field, probably no one of them compares with the robin in its ability to detect and unearth grubs in lawns, a fact which makes them doubly valuable since grubs are much more difficult to control in grass lands than in cultivated fields. Evidently robins detect the grub by their keen sense of hearing, and having once ascertained its location they 
vigorously dig into the sod until it is unearthed. Mr. E. H. Forbush (28) reported an unusual abundance of white-grubs in a cranberry bog at Wareham, Mass., nearly every plant being killed; but the following season robins appeared in large numbers, and by digging into the soil and pulling out the grubs they practically cleared the field of the pests. The crow is often similarly active in destroying white-grubs in sod land, especially when they are abundant. In 1912 the writer saw a badly infested pasture at Galena, I1l., in which the sod had been literally overturned by the crows in their search for grubs.

\section{Wild Mammals and Amphibians}

Of the mammals known to destroy white-grubs and the parent May-beetles the common skunk (Mephitis mephitis-P1. XV, Fig. 60) is undoubtedly the most important, and it has been repeatedly mentioned, since the early records by Harris, as a very efficient destroyer of whitegrubs. In spealing of the remarkable capacity and fondness of skunks for grubs Dr. Lintner remarks (45): "I have often watched them, and, incredible as it may seem, I could not say that they ate less than half a bushel daily." Mr. D. E. Lantz, in his discussion (14) of the "Economic Value of North American Skunks", speaks of the common skunk (Mephitis mcphitis), the white-backed skunk (Conepatus sp.), and the little spotted skunk (Spilogale intermpta) as very important destroyers of white-grubs and May-beetles, basing his conclusions on extensive field observations as well as on studies of stomach contents; and other workers of the U. S. Biological Survey (21) write similarly. Mr. Frank C. Pellett (5t) concludes from five years' observation of this mammal in the field and in confinement that it is a valuable friend in destroying insect and rodent pests, and that "the poultry-killing habit is accidental and unusual and confined to a small percentage of the individuals". Because of its nocturnal habits the skunk is seldom seen at work, but Mr. Norman Criddle (14) tells of watching a skunk catching Mayheetles at night, and later in the season, after the beetles had disappeared, of observing the activities of slinnks in search of grubs. In an 8 -acre field infested with white-grubs, near Aweme, Manitoba, the work of two or more sliunks was quite apparent, and he estimated that they had destroyed 116,160 grubs in this one field.

In connection with our own studies we have frequently observed the work of the skunk. In 1912 Mr. Henry Gesle, of McGregor, Iowa, told us of observing an old skunk roll up grub-infested sod, thus exposing the grubs, which she and her young ate eagerly. More often the animal detects the presence of a gruh by a keen sense of smell and secures it by digging a small hole at the spot where she knows it to be. The writer was called to Lagro, Ind., November 3, 1911, to investigate a reported white-grub injury to fall wheat. A week previous the grubs were common near the wheat plants, cutting off the roots, but on the day when we visited the field scarcely a gruh could be found, most of them having been destroyed by skunks; at nearly every stalk of wheat 
showing grub injury the typical skunk excavation was to be found but no trace of living grubs. A similar observation was made in an infested wheat field October 9, 1914, near Battle Creek, Mich. The farmers in the infested districts of Illinois, Michigan, Wisconsin, and Iowa are realizing the economic importance of the skunk, and are in many cases prohibiting hunters from killing it, and in other ways giving it their protection.

The common mole (Scalopus aquaticus) is probably next in importance. Mr. Theo. H. Scheffer (65), after examining the stomach contents of 200 moles taken in all months of the year, concludes that white-grubs and earthworms constitute the bulk of their food; and $\mathrm{Mr}$. J. A. West ( 82$)$ finds from a study of the stomach contents of moles collected under varying conditions in various parts of Illinois, that a good per cent. of the food of moles consists of white-grubs and Maybeetles.

Mr. George G. Ainslie, of the Bureau of Entomology, made some interesting observations on the feeding habits of the common mole in confinement. The mole, which was taken in a field at Nashville, Tenn., June 28, 1911, was fed ten large Phyllophaga grubs, two wireworms, and one web-worm in succession, all of which it ate with relish. The mole would eagerly take a grub, quickly crush its head between its teeth, and leisurely eat the remainder of the grub.

At Farmington, Mich., October 23, 1914, A. F. Satterthwait saw an abundance of mole tunnels in an old timothy sod badly infested with grubs, the untstal amount of mole work in this field indicating that they, as well as skunks, were attracted there to feed on the grubs. A similar observation was made by Joe S. Wade, of the Bureau of Entomology, at Shawnee, Okla., the mole tunnels being conspicuous, especially in the worst-infested parts of the field. At Ashboro, Indiana, we found a quantity of May-beetle remains at the end of a mole tunnel, and on several occasions have traced the mole-runs in corn fields infested with grubs and found them leading directly to hills where grub injury had occurred. All our field observations indicate that the moles play a significant rôle in the natural control of white-grubs.

Other animals which have been seen to feed on white-grubs or May-beetles are the raccoon (Procyon lotor), the coyote (Canis latrans), the fox, the opossum (Didelphys virginiana), and the gopher. (21, 45, 55.) The first three are comparatively rare in most regions where whitegrubs are important pests, and the ultimate value of the gopher is questionable because of its injury to farm crops. Mr. J. S. Wade received a letter from a farmer of Shawnee, Okla., dated July 3, 1913, who reports killing a small striped gopher, or ground-squirrel-supposedly Citellus tridecemlineatus-in the immediate vicinity of grub-infested hay land and of examining its stomach, which contained about a dozen partly disintegrated grubs. Franklin's spermophile (Citellus franklini) feeds on white-grubs, according to an examination of the stomach con- 
tents made by Mr. Vernon Bailey (3); and such animals as the weasel, martin, wolf, and hedgehog are said to feed on white-grubs $(1 \%, 59)$.

The shrew is also well known for its fondness for May-beetles and white-grubs, and A. F. Shull $(67)$ estimates that a single short-tailed shrew (Blarina brevicauda) during one month might kill and use for food 450 May-beetles; and Mr. F. E. Wood (83) writes: "Probably no other mammal [referring to the above species], unless it be the skunk when on its good behavior, is so uniformly beneficial to the farmer."

The badger (Taxidea taxus) is very fond of white-grubs, and in some regions its beneficial activities have been noticeable. At Deford, Mich., July 25, 1913, Mr. A. F. Satterthwait, of the Bureau of Entomology, saw a white-grub-infested June-grass sod of about three acres dug up in a way that suggested the work of swine in rooting for grubs, and, on inquiry, Mr. Earl Lockwood, the owner, stated that badgers which lived in the adjacent woods were responsible for this work.

The common toad (Bufo americanus) is very fond of May-beetles and has been seen at night beneath electric lights, feeding on the beetles as they drop, and during the evening in pastures, capturing May-beetles as they issue from the soil. At Wellington, Kan., May 23, 1911, E. G. Kelly saw toads eating beetles beneath lights and as they emerged from the grass in the evening, and in one case he noticed that a single toad ate more than nineteen beetles in succession. Mr. A. H. Kirkland (43) concludes from an examination of the stomach contents of many specimens that May-beetles constitute about 6 per cent. of the food of the common toad, and similar conclusions have been reached by other observers.

Frogs are also known to feed on May-beetles. In one frog's stomach examined by Mr. C. W. Hargitt six May-beetles were found (33); in another, that of a medium-sized frog, as many as ten beetles were found, according to G. H. Perkins (55) ; and P. R. Hoy (3!) speaks of having found 8 May-beetles in a large spotted frog.

The slimy salamander (Plethodon glutinosus) may eat May-beetles, according to observations by Prof. H. A. Surface $(71)$, who found the remains of a Phyllophaga adult among the stomach contents of this animal.

Field mice also evidently feed to some extent on May-beetles. At Deford, Mich., June 25, 1914, A. F. Satterthwait found quantities of May-beetle fragments under trash in mice runways at the base of a partially defoliated Carolina poplar; and G. H. Perkins (55) reports mice (probably referring to field mice) as feeding on Phyllophaga.

\section{Domestic Animals}

None of the enemies of Phyllophaga that have been mentioned rank as high in this rôle as do some of our domestic animals, and of these pigs are by far the most important. Their fondness for May-beetles and white-grubs, more especially for the latter, has been commonly observed, and their use for controlling white-grubs has been recommend- 
ed for years. (P1. XIV, Fig. 58.) If pastured in infested ground, pigs will literally plow up the land in their search for grubs, and in a short time will practically eradicate the pests. Dr. Forbes (26) made an experiment to determine accurately the value of the pig in destroying grubs. One hundred pigs and 8 sows were turned into an enclosed $10-$ acre field September 23 , and within 20 days 86 per cent. of the grubs were destroyed, and in 27 days less than 1 per cent. of the original infestation remained-a benefit of over 99 per cent. If we estimate 34.6 grubs per hill-the count made at the beginning of the experimentand 3556 hills to the acre (hills $31 / 3$ feet apart each way) it will be seen that the pigs destroyed something like $1,218,067$ grubs in 27 days, that is, 11,278 grubs per animal. It was further noted that the pigs apparently suffered no ill effects from the continuous grub-ration.

An interesting and illustrative account of the probable important rôle played by swine in the control of white-grubs in Texas twenty or more years ago was given us by $\mathrm{Mr}$. N. Mowinkle, a resident of Texas for over sixty years, and of Travis county, where the grubs have recently caused immense losses, for most of this time. Until comparatively recent years it was the custom of the Indians to burn over the mesquite meadows every fall, and hogs were always given free range. Previous to the year $187 \%$ no fencing of any kind was used, but about that time barbed wire came into use. Burning over the land was discontinued fifteen or twenty years ago and laws requiring that hogs should be fenced were enacted. About ten, or possibly twelve, years ago the white-grubs began to destroy the pastures; in other words, they first appeared in injurious numbers five to seven years after the burning over of the land was discontinued and fencing for hogs was required. No doubt these two changes in the situation were in a large measure responsible for the increase of the white-grubs in certain parts of Texas.

That the eating of white-grubs under certain conditions may be harmful to pigs, occasioning infestation with intestinal parasites, has been shown by Dr. C. W. Stiles (69), who says that the giant thornheaded worm (Gigantorhynchus hirudinaceus $=$ Echinorhynchus gigas), an injurious intestinal parasite of swine (Fig. 46), passes one stage of its life in the bodies of white-grubs of the genus Phyllophaga,* the pigs obtaining them by eating infested grubs, which themselves become infested by way of the excrement of parasitized pigs. Especial care should be taken to pasture brood sows in fields on which pigs have not been pastured for two or more years.

Turkeys are extremely fond of grubs and we have seen the sod of pastures overturned by these birds in their search for the pests.

Chickens are not so active as turkeys in their search for grubs in unplowed ground, but it is wise to encourage them to follow the plow and cultivator whenever possible, and they will eagerly pick up every grub or May-beetle exposed. In one case which has come to our at-

* Other authors have shown a similar relation to exist between this worm and two common European grubs (Aielolontha vulgaris and Cetonin rurata). 
tention a heavily infested 15 -acre field was cleaned of grubs by giving poultry the run of the field during cultivation. Another instance of the value of chickens in this connection was called to our attention by Mr. Frank Acker, of Middleton, Wis., whose potato crop was practically destroyed by grubs in 1912 excepting the part near the farm buildings, where the clickens had the run of the field. When sod is loose because its roots are cut off by grubs, chickens will scratch it away in their search for the insects much as do turkeys. When the beetles are abundant, on nearly every farm the chickens may be seen searching for Nay-beetles beneath the trees.

Portable poultry houses, which can be transferred to any particular field or part of a field as it is being plowed or cultivated, were used in

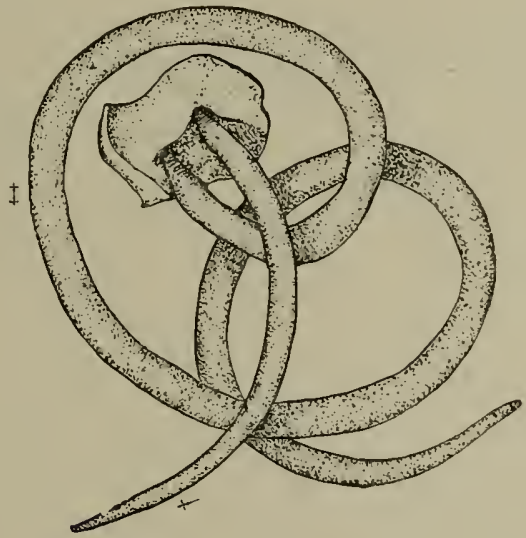

Fig. 46. Thorn-headed worms /Gigantorhynchus hirundinaceus) attached to piece of pig's intestine: $\downarrow$, male: $\ddagger$, female. Enlarged. (Redrawn from Ransom, Yearbook U. S. Dept. Agr., 1905.)

Europe over fifty years ago. Such houses, according to M. Maurice Girard (30), should have a capacity for 100 to 200 chickens, and should contain perches, numerous egg-laying compartments, and a receptacle to catch the manure. The clickens forage about the house during the day, returning at night, and a continuous ration of grubs has no perceptible effect on the taste ot the eggs as does a continuous ration of certain lepidopterous larvae.

Rarely dogs have been trained to follow the plow and pick up beetles and grubs (1\%). At Washington, Ind., April 16, 1915, Mr. D. G. Tower, 
of the Bureau of Entomology, observed a black and tan terrier following a plow and eating the grubs as they were exposed. The dog seemed to find the grubs by scent as well as by sight, for frequently it would dig for those which were completely covered. Most of those eaten, according to Mr. Tower's observation, were Cotinus (Allorhina), but undoubtedly the dog would have eaten Phyllophaga grubs with relish had they been as abundant.

It is well known that many cats are fond of May-beetles. Prof. $\mathrm{H}$. A. Surface $(70)$ reports that a cat in his possession would catch Maybeetles as they came out of the ground in the evening, and that it once ate so many that it was made sick and vomited nearly a pint of Maybeetle remains. 


\section{ERrita}

Page 97, line 17, for first larval in the line, read pupal.

Page 112, in legend, for jonessi read jonesii.

Page 114, in legend, for or read of.

Page 131, in legend, for hirundinaceus read hirudinaceus.

Page 138, last line, for coccoon read cocoon.

Plate XII, explanation page, next to last line, for acrivora read aerivora.

Plate XIII, explanation page, next to last line, for White-grubs read White-grub. 


\section{LITERATURE CITED}

Aldrich, J. M.

(1) 1905. A catalogue of North American Diptera. Smiths'n Misc. Coll. No. 1444 (Vol. 46). 680 p.

(2) 1916. Sarcophaga and allies in North America. The Thomas Say Foundation of Ent. Soc. Amer. 302 p., 16 pl.

Bailey, Vernon

(3) 1894. The prairie ground squirrels or spermophiles of the Mississippi Valley. U. S. Dept. Agr. Div. Ornith. and Mamm. Bul. 4. 5i p.

Beal, F. E. L.

(4) 1895. The crow blackbirds and their food. Yearbook U. S. Dept. Agr. 1894 : 233-248, 1 fig.

(5) 1912. Food of our more important flycatchers. U. S. Dept. Agr. Bur. Biol. Surv. Bul. $44.6 \imath$ p., 5 pl.

(6) 1913. Our meadow larks in relation to agriculture. Yearbook U. S. Dept. Agr. 1912 : 2\%9-284.

(7) 1915. Food of the robins and bluebirds of the United States. U. S. Dept. Agr. Bul. 1i1. 31 p., 尺 fig.

(8) 1915. Some common birds useful to the farmer. U. S. Dept. Agr. Farmers' Bul. 630. 27 p., 23 fig.

Beal, F. E. L., and McAtee, IV. L.

(9) 1912. Food of some well-known birds of forest, farm, and garden. U. S. Dept. Agr. Farmers' Bul. 506. 35 p.. 16 fig.

Brues, C. T.

(10) 1916. A new species of Lepidopria from North America. Psyche, $23: 126-12 \%$, 1 fig.

Burrill, A. C.

(11) 1914. The "Fisherman's Friend" is also the farmer's friend. IVis. Horticulture, 4 (No. 5) : $3-4.1$ fig.

Cist, Jacob

(12) 1824. Notice of the Melolontha, or May bug. Sill. Am. Jour. Sci. and Arts, $8: 269-2 \approx 1,1 \mathrm{pl}$.

Coquillett, D. W.

(13) 1897. Revision of the Tachinidae of America north of Mexico. U. S. Dept. Agr. Div. Ent. Tech. Ser. No. \%. 156 p. 
Criddle, Norman

(14) 1914. The value of some mammals and birds as destroyers of noxious insects. Ottawa Naturalist, 28 (No. 9) : 119124.

Davis, John J.

(15) 1913. Common white grubs. U. S. Dept. Agr. Farmers' Bul. 543. 20 p., 12 fig.

(16) 1916. A progiess report on white grub investigations. Jour. Econ. Ent. 9 (No. 2) : 261-281, 2 pl.

Devereaux, W. L.

(1i) 1890. The May beetle and the white grub. Insect Life [U.S. Felt, E. P. Dept. Agr.] 2 (No.11-12) : 3テ2-374.

(18) 1915. White grubs and June beetles. Twenty-ninth (1913) Rep. State Ent. N. Y., (Bul. 175 N. Y. State Mus.) p. Fisher, A. K. 24-26.

(19) 1893. The hawks and owls of the United States in their relation to agriculture. U. S. Dept. Agr. Div. Ornith. and Mamm. Bul. 3. 210 p., 26 pl.

(20) 1895. Hawks and owls as related to the farmer. Yearbook U. S. Dept. Agr. 1894 : 215-232, 4 fig., 3 pl.

(21) 1909. The economic value of predaceous birds and mammals. Yearbook U. S. Dept. Agr. 1908 : 187-194. 3 pl.

Flint, W. P., and Sanders, G. E.

(22) 1912. Note on a parasite of white-grubs. Jour. Econ. Ent 5 (No. 6) : 490 .

Forbes, S. A.

(23) 1880. The food of birds. Bul. Ill. State Lab. Nat. Hist. 1 (No. 3, 2d ed.) : 86-161.

(24) 1891. On the common white grubs. Seventeenth Rep. State Ent. Ill. (1889-90), p. 30-53, 1 pl.

(25) 1894. The white grubs. Eighteenth Rep. State Ent. I1l. (1891$92)$, p. $109-144,10$ fig.

(26) $190 \%$ On the life history, habits, and economic relations of the white-grubs and May-beetles (Lachnosterna). Ill. Agr. Exper. Sta. Bul. 116:147-180; also (1908) 24th Rep. State Ent. I1l, p. 135-168, 3 col. pl.

Forbush, Edward Howe

(27) 1915. The starling. Mass. State Bd. Agr. Cir. 45. 23 p., 1 fig., 1 pl.

(28) 1916. Eighth annual report of the state ornithologist. Sixtythird Ann. Rep. Mass. State Bd. Agr. 1915:79-108, 5 fig., $9 \mathrm{pl}$., and frontispiece. Also issued as a separate.

Gahan, A. B.

(29) 1913. New Hymenoptera from North America. Proc. U. S. Nat, Mus. 46 (No. 2035) : 431-443, 1 pl. 
Girard, Maurice

(30) 1866. Sur l'emploi des poulaillers roulant pour combattre les ravages des larves de hannetons. Ann. Soc. Ent. France,

Girault, A. A. ser. $4,6: 571-5: 6$.

(31) 1916. A new Phanurus from the United States, with notes on allied species. Can. Ent. 48 (No. 5) : 149-150.

Glover, Townend

(32) 1866. Report of the entomologist. Rep. U. S. Comm. Agr. Hargitt, C. IV. $1865: 33-45$.

(33) 1889. [Vertebrate enemies of the white grub.] Abstract, Hart, C. A. Insect Life [U. S. Dept. Agr.] 2 (No. 6) : 195.

(34) 1895. On the entomology of the Illinois River and adjacent waters. Bul. Ill. State Lab. Nat. Hist. 4 : 149-273; $278-$ 284. $15 \mathrm{pl}$.

Henshaw, Henry $W^{\text {. }}$, et al.

(35) 1913. Fifty conmon birds of farm and orchard. U. S. Dept. Hine, James S. Agr. Farmers' Bul. 513. 31 p., 50 fig.

(36) 1906. Habits and life histories of some flies of the family Tabanidae. U. S. Dept. Agr. Bur. Ent. Tech. Ser. No. 12, Pt. 2: 19-38, 12 fig.

(37) 1906. A preliminary report on the horseflies of Louisiana, with a discussion of remedies and natural enemies. State Crop Pest Comm. La. Cir. 6. 43 p., 20 fig.

Hoy, P. R.

(38) 190\%. Second report upon the horseflies of Louisiana. La. Agr. Exper. Sta. Bul. 93. 59 p., 37 fig.

(39) 1881. [Frogs as enemies of May-beetles.] Trans. Wis. State Agr. Soc. $1880-81,19: 29 \%$.

Johnston, John R.

(40) 1915. The entomogenous fungi of Porto Rico. Bd. Comm.

Judd, Sylvester D. Agr. Porto Rico Bul. 10. 33 p., 9 pl.

(41) 1901. The food of nestling birds. Yearbook U. S. Dept. Agr. $1900: 411-436$.

(42) 1904. The economic value of the bobwhite. Yearbook U. S.

Kirkland, A. H. Dept. Agr. 1903 : 193-204.

(43) 1904. Usefulness of the American toad. U. S. Dept. Agr.

Lantz, D. E. Farmers' Bul. 196. 16 p.

(44) 1904. Economic value of North American skunks. U. S. Dept. Agr. Farmers' Bul. 587 : 10-12. 
Lintner, J. A.

(45) 1888. The white grub of the May beetle. N. Y. State Mus. Nat. Hist. Bul. 5. 31 p., 5 fig. Also (1889) in Trans. Lugger, O.

N. Y. State Agr. Soc. for $1883-86$, Vol. 34.

(46) 1884. [Parasite of Tiphia, etc.] Psyche, 4: 211.

Malloch, John R.

(4i) 1915. Some additional records of Chironomidae for Illinois and notes on other Illinois Diptera. Bul. III. State Lab. Nat. Hist. 11 (Art. 4) : 306-363, 5 pl.

(48) 1916. A comparison of the pupae of Promachus vertebratus and $P$. fitchii (Diptera). Bul. Brooklyn Ent. Soc. 11 (No. 3) :66-68.

(48a)1916. The generic status of Chrysanthrax fulvohirta Wied. Proc. Biol. Soc. Wash. 29:6\%.

(49) 191\%. A preliminary classification of Diptera, exclusive of Pupipara, based upon larval and pupal characters, with keys to imagines in certain families. Part I. Bull. Ill. State Lab. Nat. Hist. 12 (Art. 3). 249 pp., 30 pl.

(49a)1918. The North American species of the genus Tiphia (Hymenoptera, Aculeata) in the collection of the Illinois State Natural History Survey. Bul. Nat. Hist. Surv. $13: 1-24,1$ pl.

McAtee, W. L., and Beal, F. E. L.

(50) 1912. Some common game, aquatic, and rapacious birds in relation to man. U. S. Dept. Agr. Farmers' Bul. 49\%, 30 p., 14 fig.

Merrill, J. H., and Ford, A. L.

(51) 1916. Life history and habits of two new nematodes parasitic on insects. Jour. Agr. Research [U. S. Dept. Agr.] 6 (No.3) : 115-127, 3 fig.

Northrup, Zae

(52) 1914. A bacterial disease of June beetle larvae, Lachnosterna Nowell, W. spp. Mich. Agr. Exper. Sta. Tech. Bul. 18. 37 p., 22 fig.

(53) 1915. Two scoliid parasites on scarabaeid larvae in Barbados. Ann. Applied Biol. 2 (No. 1) : 46-5\%, 1 pl.

Pellet, Frank C.

(54) 1913. Food habits of the skunk. Proc. Ia. Acad. Sci. 1913,

Perkins, G. $\mathrm{H}$. $20: 307-309,1 \mathrm{pl}$.

(55) 1892. Report of the entomologist. Fifth Ann. Rep. Vt. Agr. Exper. Sta. (1891), p. 144-159.

Pettit, R. H.

(56) 1895. Studies in artificial cultures of entomogenous fungi. Cornell Agr. Exper. Sta: Bul. 97 : 339-378, 11 pl. 
Pierce, IV. Dwight

(5\%) 191\%. Notes on a southern trip. Proc. Ent. Soc. Wash. 18 (No. 4) :206-20\%.

Rau, Pbil., and Rau, Nellie

(58) 1916. The sleep of insects; an ecological study. Ann. Ent. Riley, C. V. Soc. Amer. 9 (No. 3) : 227-274.

(59) 18\%4. The unadorned Tiphia, or white grub parasite-Tiphia inornata Say. Sixth Ann. Rep. Ins. Mo., p. 123-126, 2 fig.

(60) 1884. [Criticism of statements in (46) of this list.] Proc. Ent. Soc. Wash. 1:15.

(61) 1889. The insectivorous habits of the English sparrow (Passcr domesticus). U. S. Dept. Agr. Div. Econ. Ornith. and Mamm. Bul. 1 : 111-133.

(6?) 1889. Beetles from stomach of a "chuck-wills-widow." Insect Life [U. S. Dept. Agr.] $2($ No. 6) : 189.

(63) 1891. On the time of transformation in the genus Lachnosterna. Proc. Ent. Soc. Wash. 2 : 132-131.

Rorer, James Birch

(6t) 1913. The green muscardine fungus and its use in cane fields. Scheffer, Theo $\mathrm{H}$. Bd. Agr. Trinidad and Tobago (ir. 8.212 p., 2 fig., 2 pl.

(6.j) 1914. The common mole of the eastern United States. U. S. Schwarz, E. A. Dept. Agr. Famers' Bul. 583. 10 p., 4 fig.

(66) 1895. Report on the insect food of the crow. U. S. Dept. Shull, A. Franklin Agr. Div. Ornith. and Mamm. Bul. $6: 5 \imath-6 \tau$.

(6i) $190 \%$. Habits of the short-tailed shrew, Blarina brcicauda Stevenson, John $\AA$. (Say). Am. Nat. $41: 495-522,5$ fig.

(68) 1916. Report of the pathologist. Fourth Ann. Rep. Bd. Comm. Agr. Porto Rico, p. 33-44.

Stiles, C. W.

(69) 1892. On the American intermediate host of Echinorhynchus gigas. Zool. Anz. $15: 52-54$.

Surface, H. A.

(io) 1911. Saving animal life, or zoological conservation. Bimonthly Zool. Bul. Div. Zool. Pa. Dept. Agr. 1 (No. 6) : $2+5-2+6$.

(71) 1913. First report on the economic features of the amphibians of Pennsylvania. Bi-monthly Zool. Bul. Div. Zool. I'a. Dept. Agr. 3 (No. 3-t) : 67-152, 25 fig., $11 \mathrm{pl}$.

Sivezey, Otto $\mathrm{H}$.

(i⿱) 1915 . Some hyperparasites of white grubs. Proc. Hawaiian Ent. Soc. 3 (No.2) : $: 1-\hat{\imath} 2$. 
Titus, E. S. G.

(i2) 1905. The sugar-cane beetle (Ligyrus rugicsps Lec.), with notes on associated species. U. S. Dept. Agr. Bur. Ent. Bul. $54:$ i-18, 6 fig.

Townsend, C. H. T.

(it) 1893. Hosts of North American Tachinidae, etc. I. Psyche, $6: 466-468$.

(i5) 1908. The taxonomy of the muscoidean flies, including descriptions of new genera and species. Smiths'n Misc. Coll. No. 1803 (Vol. 51), p. 106.

Urich, F. IV.

(6) 1913. The sugar-cane froghopper (Tomaspis varia Fabr.). Van Dine, D. L. Bd. Agr. Trinidad and Tobago Cir. $9:--2 \%, 3$ fig., 9 pl.

(\%) 1912. Progress report on introductions of beneficial parasites into Porto Rico. First Rep. Bd. Comn. Agr. Porto Rico, p. $31-4 \%$.

(i8) 1913. The introduction of parasites of May-beetles into Porto Rico. Sec. Rep. Bd. Conm. Agr. Porto Rico, p. 36-18.

Van Zwaluwenburg, R. H.

(i9) 1915. Report of the entomologist. Rep. Porto Rico Agr. Exper. Sta. 191t: 31-35.

Walton, IV. R.

(80) 1912. A new species of Tachinidae from Porto Rico. Proc. Ent. Soc. Wash. $14: 198-200,1$ pl.

(81) 1913. New North American Tachinidae (Dipt.). Ent. News Viest, James A. 24 (No.2) : 49-52, $1 \mathrm{pl}$.

(82) 1910. A study of the food of moles in Illinois. Bul. Ill. State Lab. Nat. Hist. 9 (Art. 2) : 14-22.

Wrood, Frank Elmer

(83) 1910. A study of the mammals of Champaign county, Illinois. Bul Ill. State Lab. Nat. Hist. 8 (Art. 5) : 501-613, 12 fig. $3 \mathrm{pl}$.

\section{Plate III}

Fig. 1, 2. Mature Tiphia larvae eating the last remains of a white-grub. Natural size.

Fig. 3. Same larva, a few hours later, beginning foundation of cocoon. Natural size.

Fig. 4. Completed cocoon in a tin-box cage.

Fig. 5, 6. Tiphia punctata larvae in their characteristic position on grub; front and rear views. Natural size.

Fig. 7. Tiphia cocoon from which a parasite (Anthrar parvicornis) has issued, characterized by the squarely cut-off tip of coccoon. 
Plate III
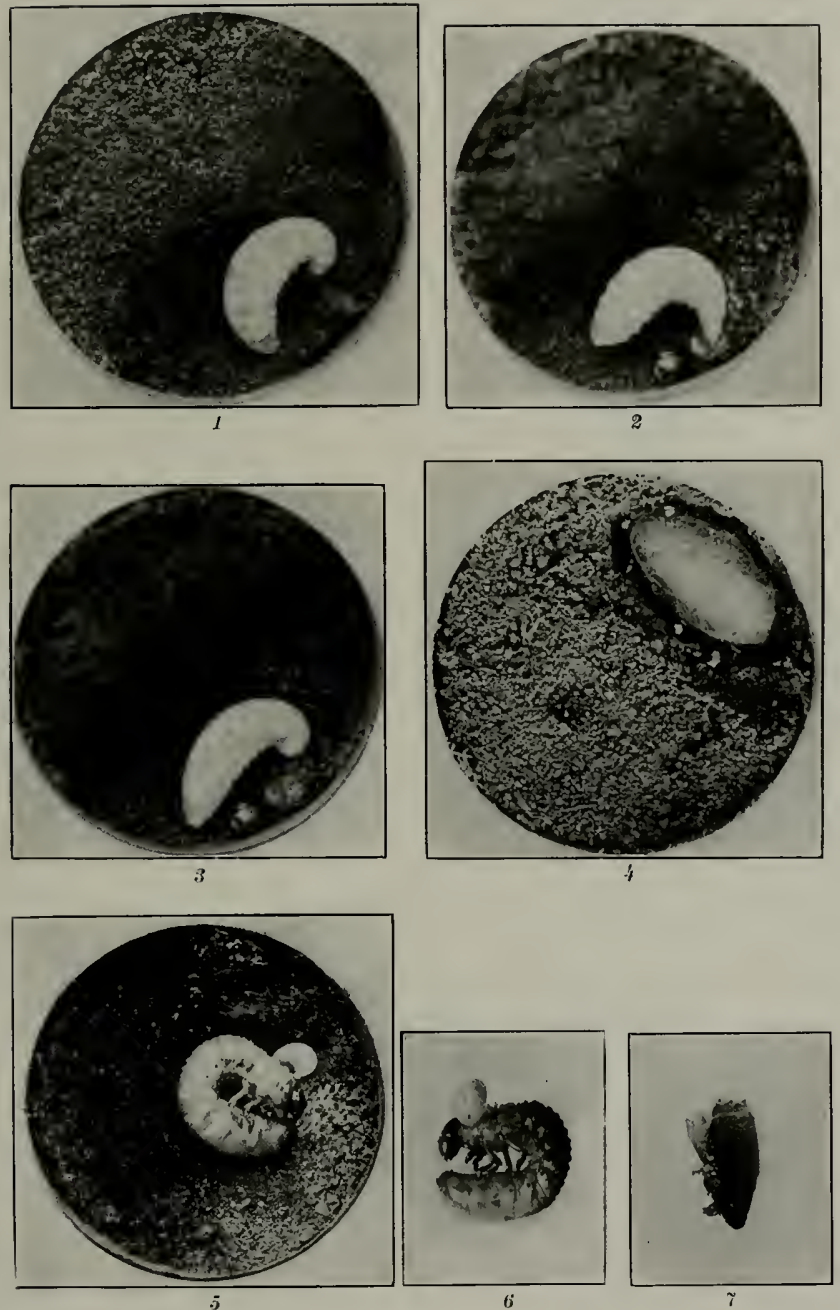
Plate IV

Fig. 8, 9. Tiphia cocoons, enlarged and natural size.

Fig. 10, 11. Elis cocoons, enlarged and natural size.

Fig. 12. Chrysanthrax fulvohirta Wied., a parasite of Elis. Enlarged. 
Plate IV
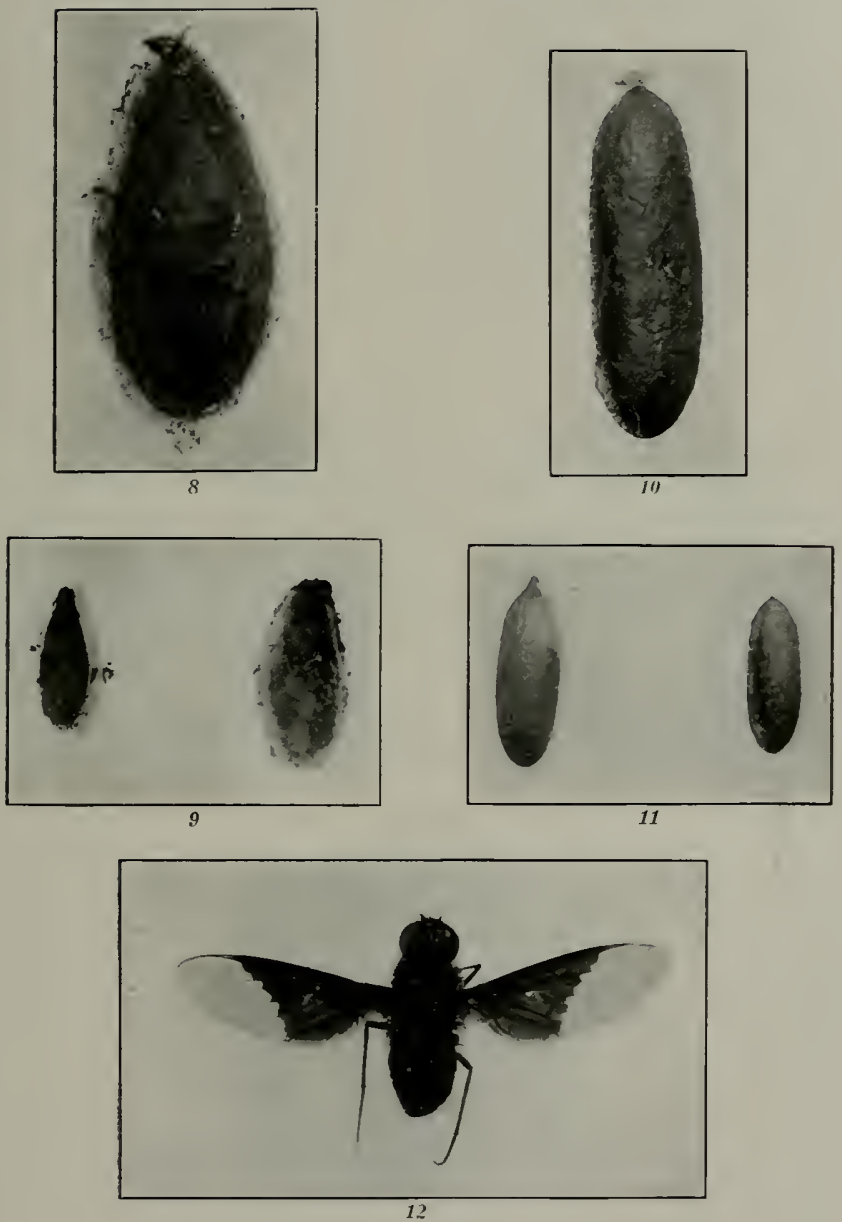


\section{Plate V}

Fig. 13. Elis 5-cincta egg on under side of paralyzed white-grub, July 25, 1914. Natural size.

Fig. 14-16. Same grub as shown in Fig. 13, the Elis larva in Fig. 14 not over two days old, that in 15 not over four days, and that in 16 about five days. Natural size.

Fig. 17. Oblique view of Elis larva feeding on white-grub. 
Plate V
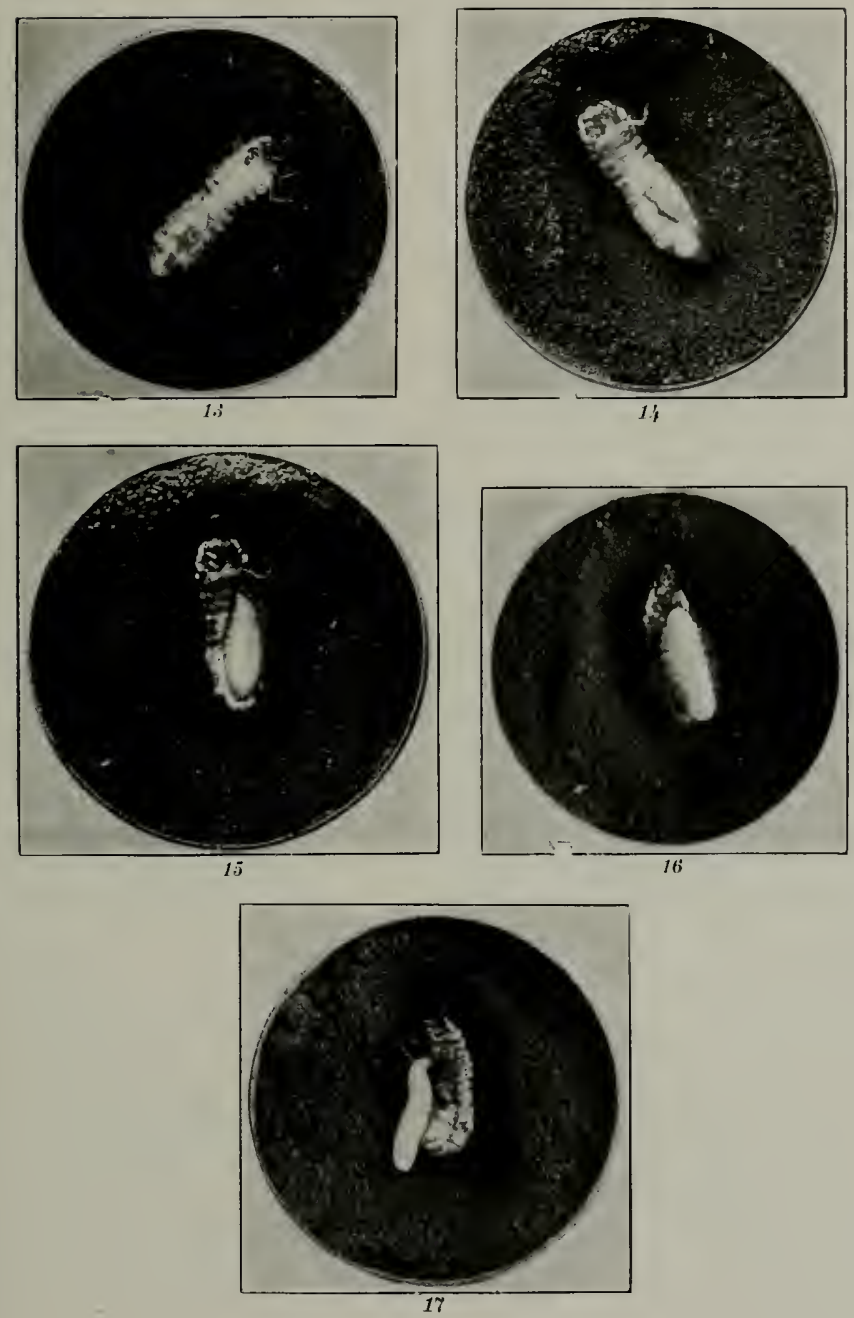


\section{Plate VI}

Fig. 18. Phyllophaga grub parasitized by Microphthalma disjuncta; the anal end of larva with the two posterior spiracles showing through body wall. Natural size.

Fig. 19. Same gruh, a day later, with Microphthalma puparium. Nothing remains of the grub but its dried and shriveled skin. Natural size.

Fig. 20. Grub parasitized by Microphthalma aisjuncta, beginning to liquefy. Natural size.

Fig. 21. A grub (Aphonus pyriformis) parasitized by several Ptilodexia harpasa maggots. No liquefaction of grub as in Fig. 20. Natural size.

Fig. 22. Microphthalma disjuncta, male, side view. Enlarged.

Fig. 23. The same, dorsal view. Enlarged.

Fig. 24. Microphthalma disjuncta puparium in dried gruh-skin as collected in the field. Natural size. 
Piate VI
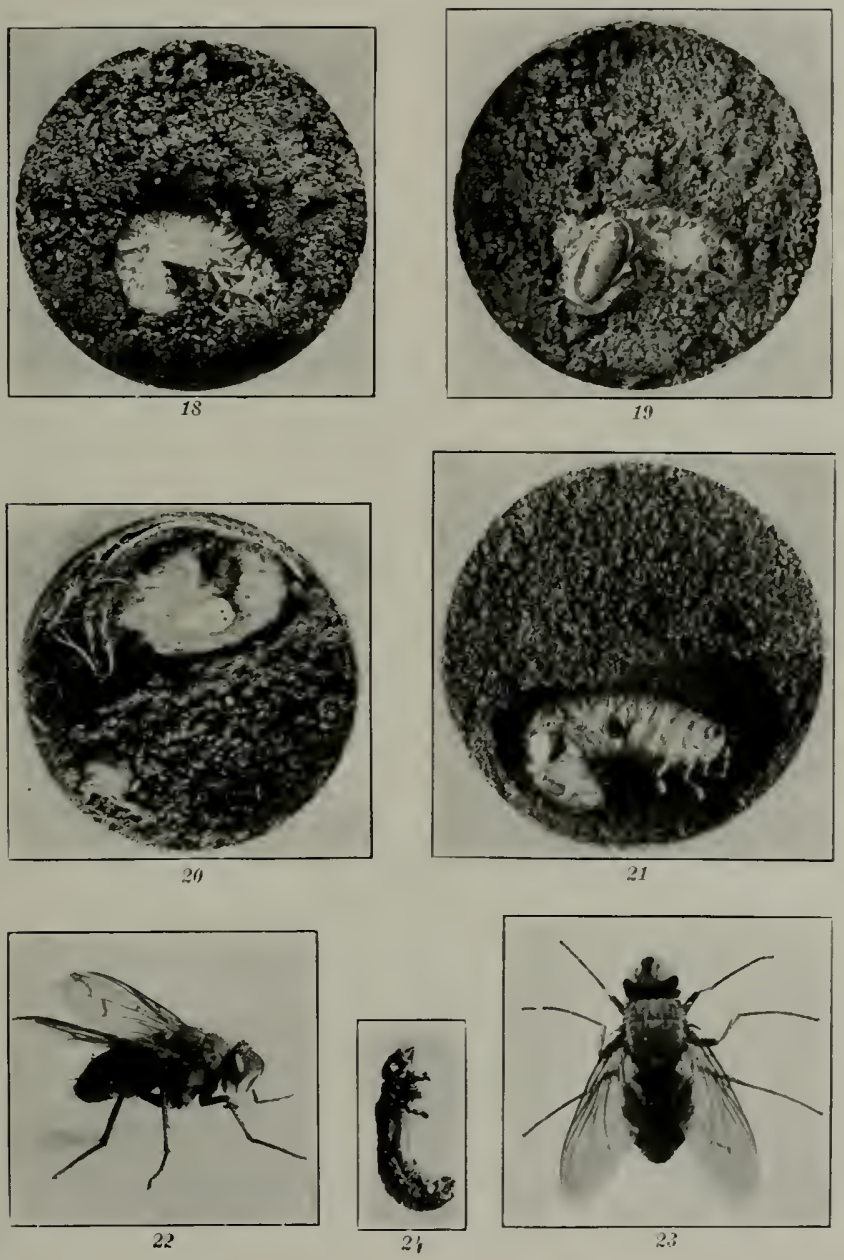


\section{Piate VII}

Fig. 25. Ptilodexia harpasa Walk., a parasite of white-grubs. Enlarged. Fig. 26. Promachus vertebratus Say. About natural size.

Fig. 27. Promachus fitchii O. S., female. About natural size.

Fig. 28. Harpalus pennsylvanicus Dej. Slightly enlarged.

Fig. 29. Pelecinus polyturator Dru., female. Natural size.

Fig. 30. Ophion bifoveolatum Brullé, female. About twice natural size. 
Plate VII
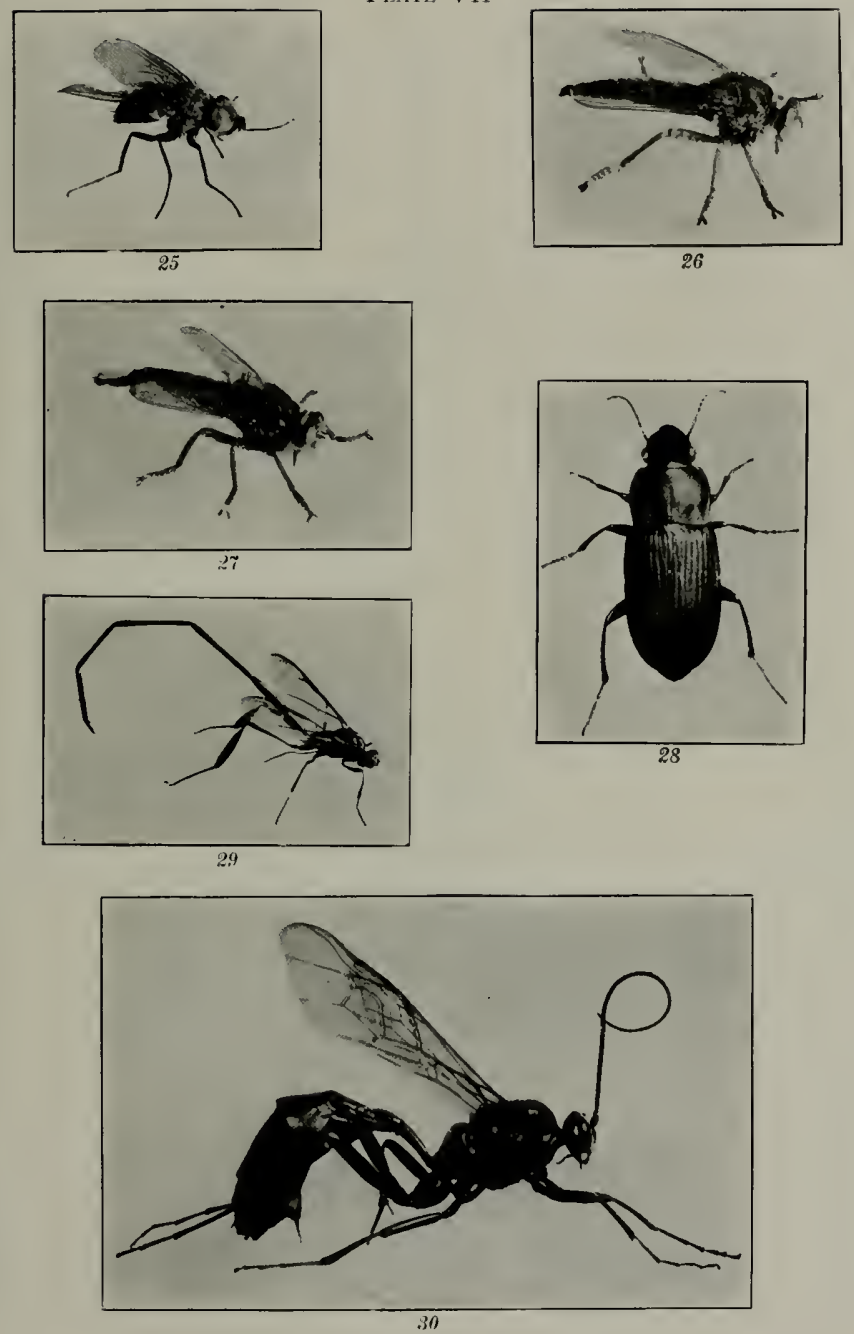


\section{Plate ViII}

Fig. 31. Deromyia winthemi Wied., male. About twice natural size.

Fig. 32. Tabanus atratus Fabr., male and empty pupal exuvia. Both enlarged to same magnification. 
Plate VIII
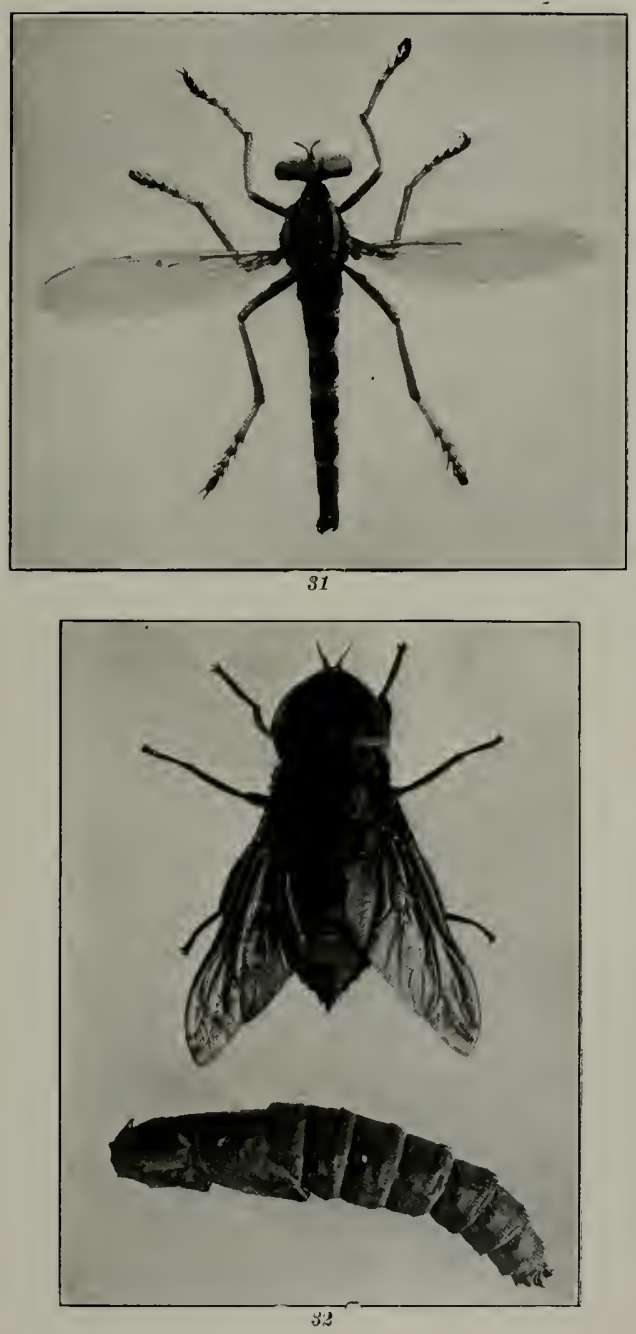


\section{Plate IX}

Fig. 33. Tabanus atratus Fabr., male. Natural size.

Fig. 34. Tabanus sulcifrons Macq., female. Natural size.

Fig. 35. Tabanus sulcifrons Macq., femals. Enlarged.

Fig. 36. The same, empty pupal exuvia. Enlarged to same magnification as Fig. 35.

Fig. 37. Tabanus atratus Fabr., egg mass and individual egg parasitized by Phanurus tabanivorus. (After Hart.)

Fig. 38. Deromyia umbrina Loew, eggs. About twice natural size. 


\section{Plate IX}

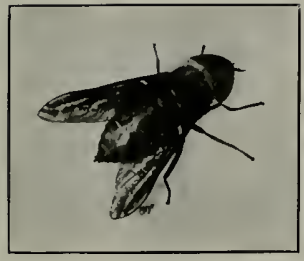

3.3

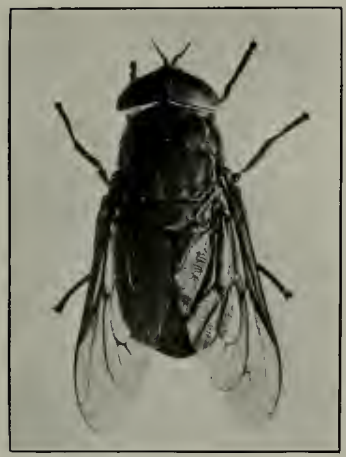

3.5

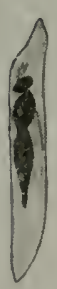

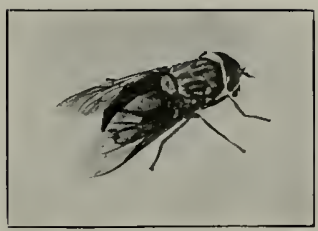

34
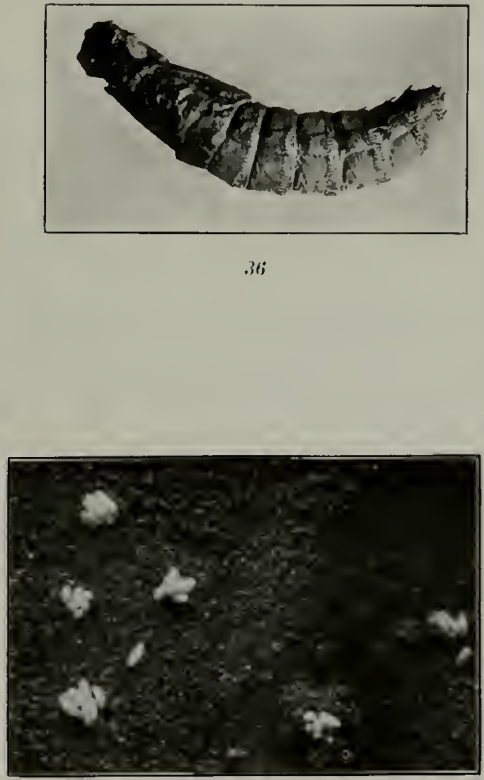

3.5 


\section{Plate X}

Fig. 39. Phanurus tabanivorus, female, an egg parasite of Tabanus atratus. (After Hart.)

Fig. 40. Phyllophaga adult bearing two eggs of Cryptomeigenia theutis on side of abdomen. Slightly enlarged.

Fig. 41. Pyrgota undata Wied. (left) and P. valida Harr. (right) puparia. Much enlarged. 
Plate X

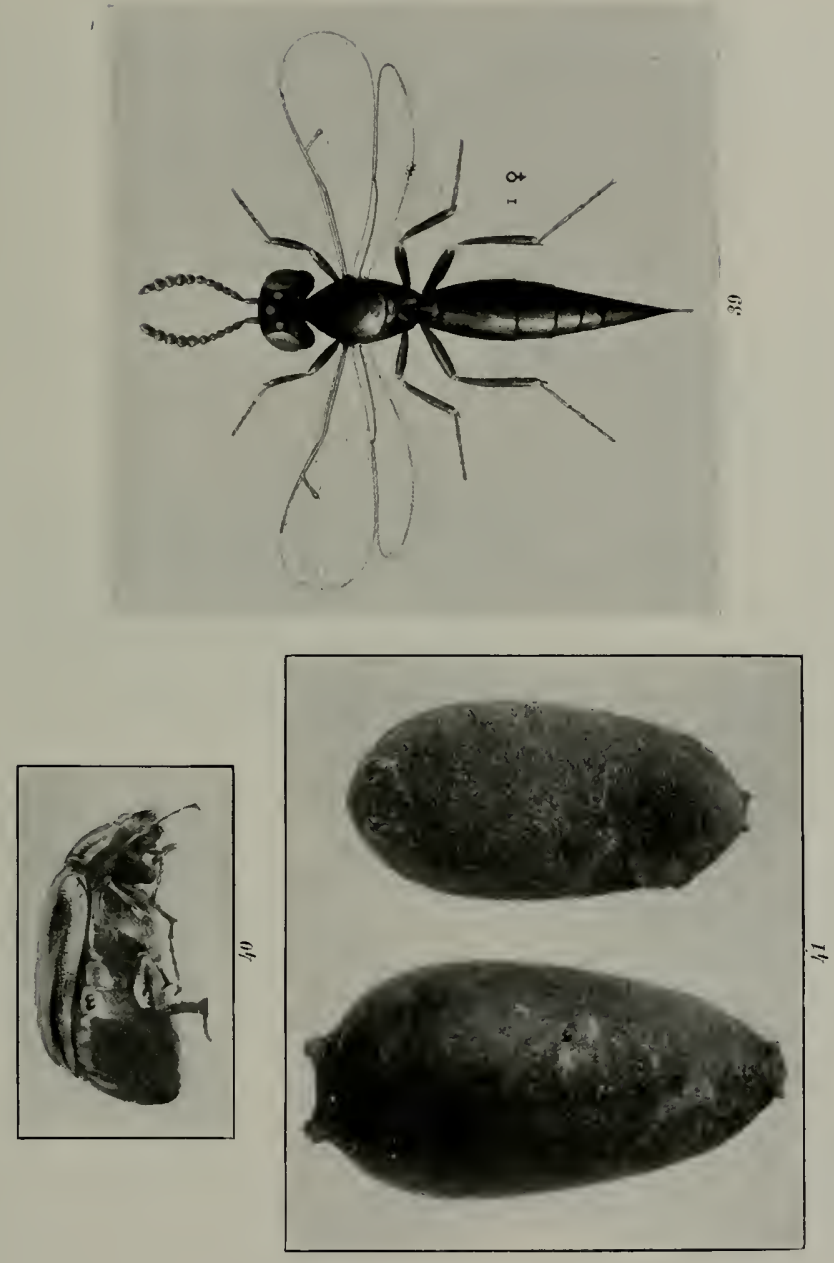




\section{Plate XI}

Fig. 42. Pyrgota valida Harr., female. Enlarged.

Fig. 43, 44. Grubs showing Mermis parasites within body. Natural size.

Fig. 45. Mermis, or hairworms, obtained from white-grubs. Natural size

Fig. 46, 47. Plectana stellata Hentz, male and female. (After McCook.) 
Plate XI
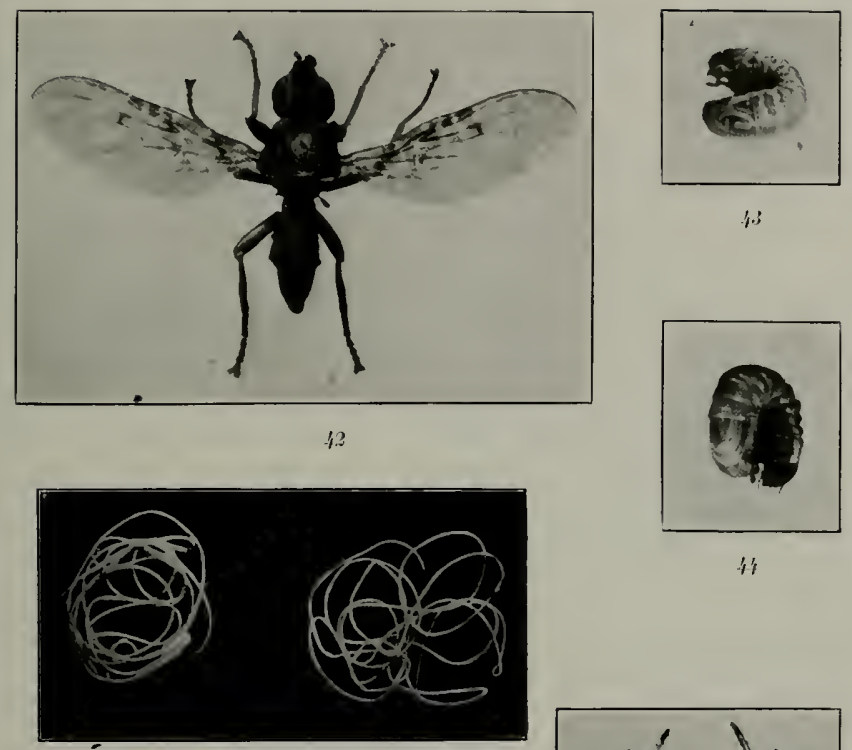

4.5

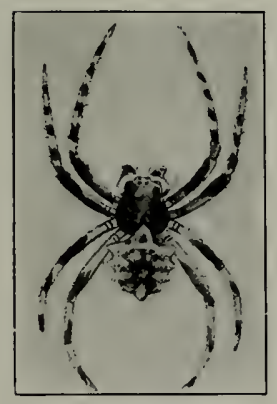

46

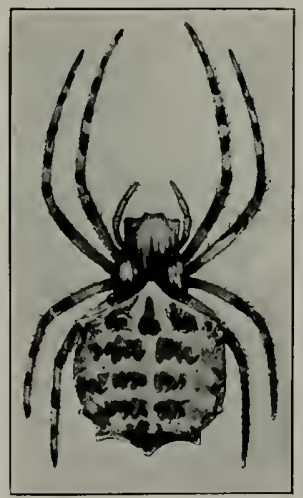

47 
PlATE XII

Fig. 48. Emaciated grubs affected by a protozoan disease. Natural size.

Fig. 49. White-grubs killed by nematodes (? Diplogaster acrivora). About natural size. 


\section{Plate XII}
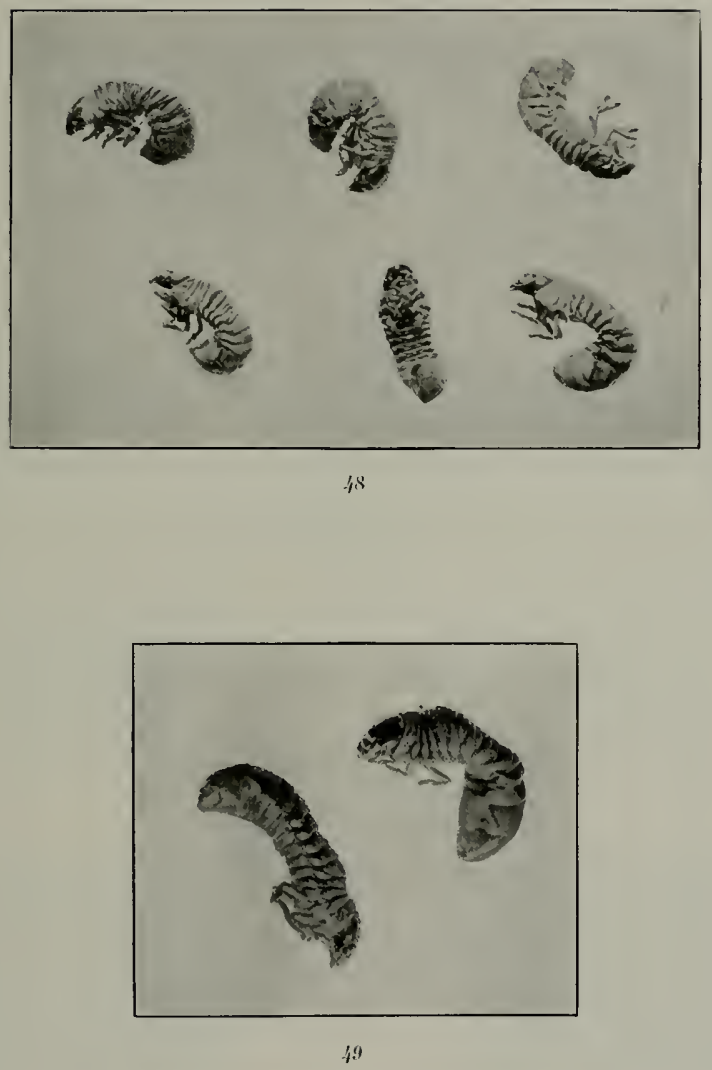


\section{PIATy XIII}

Fig. 50. Phyllophaga adults attacked by a fungous disease (due to Isaria farinosa). Natural size.

Fig. 51,52. Early stages of Metarrhizium anisopliae infection, the white mycelial threads appearing at joints of body.

Fig. 53. A later stage of Metarrhlzium, the green spores beginning to appear. Natural size.

Fig. 54. Matured green Metarrhizium spores covering body of beetle.

Fig. 55. The same covering body of a Cotalpa lanigera grub. Note characteristic beads of liquid accumulating just back of the head. Natural size.

Fig. 56, 57. White-grubs and Promachus larva covered with white mycelial threads of Metarrhizium. Natural size. 
Plate xili

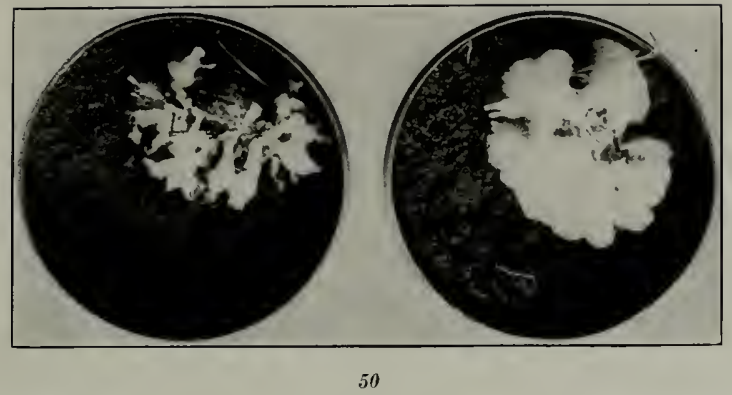

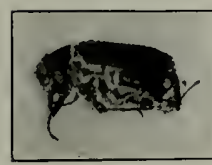

51

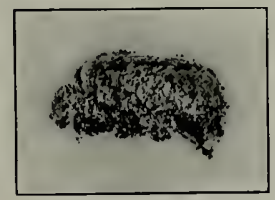

5.8

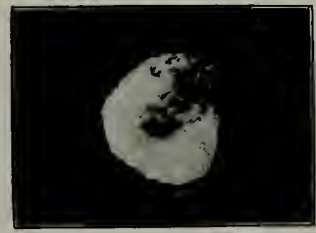

56
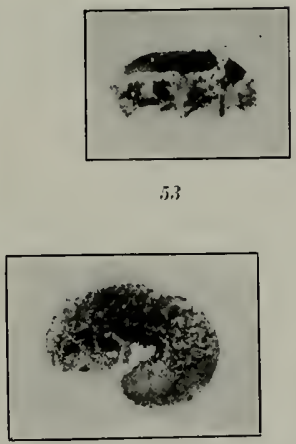

5.3

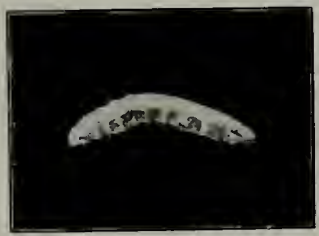

57 


\section{Plate XIV}

Fig. 58. White-grub-infested corn-field uprooted by hogs in their search for the larvae.

Fig. 59. Mummified white-grubs which have been attacked by a fungus (Isaria densa). Natural size. 
Plate XIV
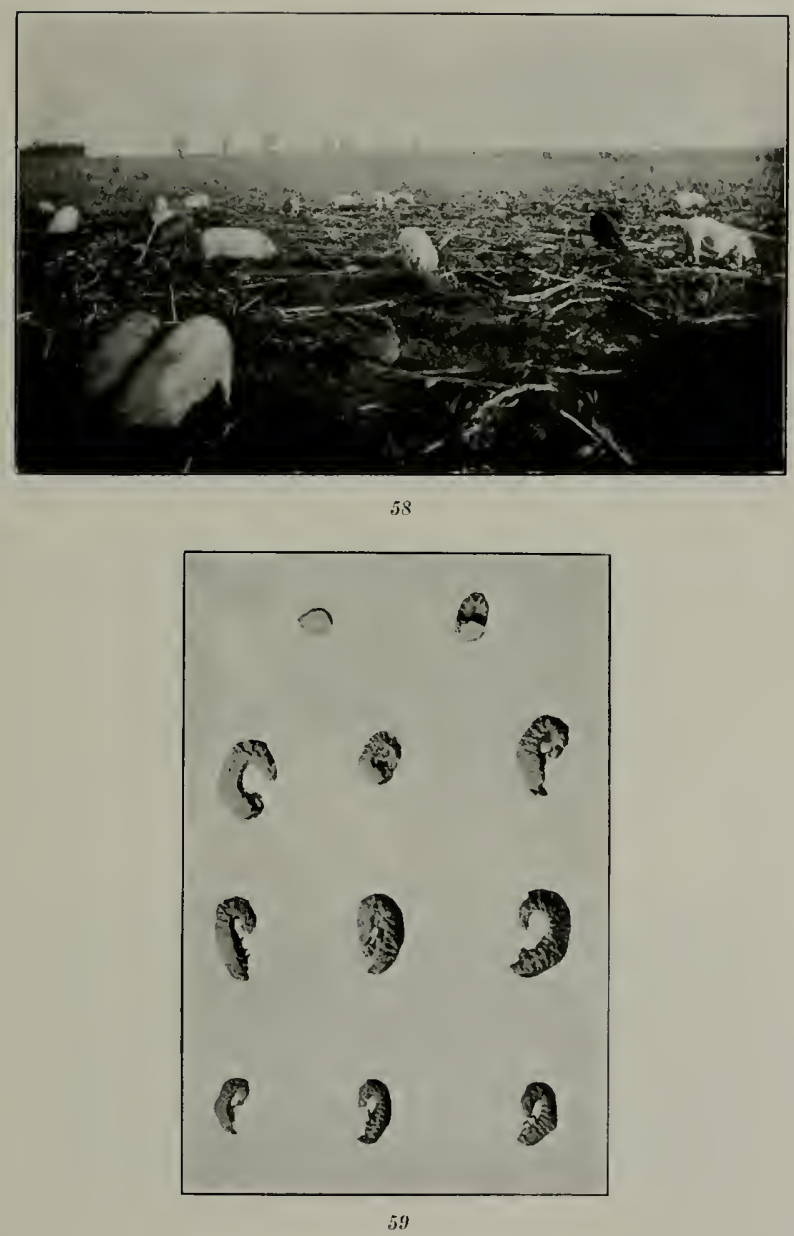


\section{Plate XV}

Fig. 60. The common skunk, Mephitis mephitis.

Fig. 61. Parasite of carabid larva, the parasite pupa attached to its host in characteristic position. Twice natural size. 
Plate XV
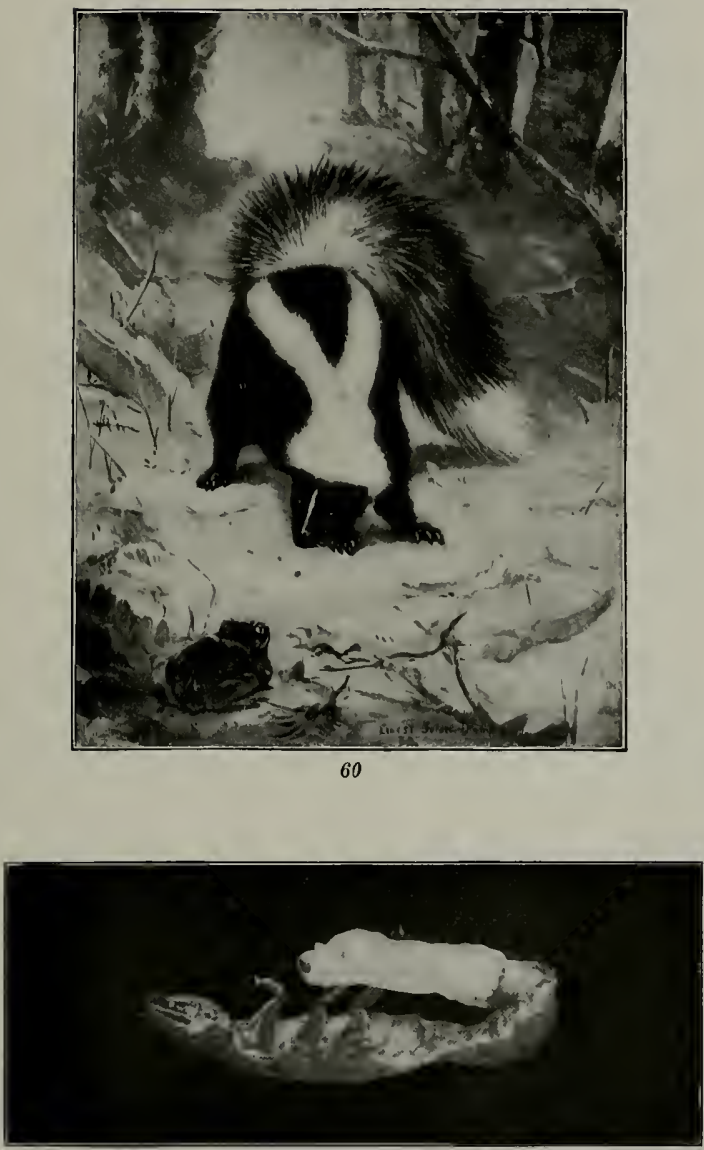